\section{Pacific Northwest}

National Laboratory

Operated by Battelle for the

U.S. Department of Energy

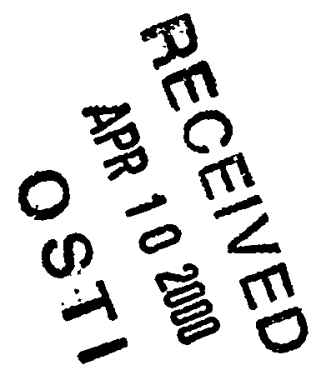

Statistical Evaluation of Effluent

Monitoring Data for the 200 Area Treated Effluent Disposal Facility

\author{
C. J. Chou \\ V. G. Johnson
}

March 2000

Prepared for the U.S. Department of Energy under Contract DE-AC06-76RLO 1830 


\section{DISCLAIMER}

This report was prepared as an account of work sponsored by an agency of the United States Government. Reference herein to any specific commercial product, process, or service by trade name, trademark, manufacturer, or otherwise does not necessarily constitute or imply its endorsement, recommendation, or favoring by the United States Government or any agency thereof, or Battelle Memorial Institute.

\section{PACIFIC NORTHWEST NATIONAL LABORATORY operated by \\ BATTELLE \\ for the}

\section{UNITED STATES DEPARTMENT OF ENERGY} under Contract DE-AC06-76RLO 1830

Printed in the United States of America

Available to DOE and DOE contractors from the Office of Scientific and Technical Information, P.O. Box 62, Oak Ridge, TN 37831; prices available from (615) 576-8401.

Available to the public from the National Technical Information Service, U.S. Department of Commerce, 5285 Port Royal Rd., Springfield, VA 22161 


\section{DISCLAIMER}

\section{Portions of this document may be illegible in electronic image products. Images are produced from the best available original document.}




\title{
Statistical Evaluation of Effiuent Monitoring : Data for the 200 Area Treated Effluent Disposal Facility
}

\author{
C. J. Chou \\ V. G. Johnson
}

March 2000

Prepared for

the U.S. Department of Energy

under Contract DE-AC06-76RLO 1830

Pacific Northwest National Laboratory

Richland, Washington 99352 



\section{Preface}

An evaluation of 4 years of effluent monitoring data for the 200 Area Treated Effluent Disposal Facility (TEDF) at the Hanford Site was conducted by Pacific Northwest National Laboratory (PNNL) during fiscal year 1999. Findings of that evaluation were presented in a draft report (dated October 1999). The draft report was used by Washington State Department of Ecology as supporting information to revise effluent monitoring requirements for the new TEDF permit that will become effective in April 2000. This report is the unabridged version of the draft report that served as technical basis for the revised monitoring requirements. 
. 


\section{Summary}

This report updates the original effluent variability study for the 200 Area Treated Effluent Disposal Facility (TEDF) and provides supporting justification for modifying the effluent monitoring portion of the discharge permit (Ecology 1995). Four years of effluent monitoring data were evaluated and used to statistically justify changes in permit effluent monitoring conditions. The permit modifications will be used to regulate and monitor TEDF at a level appropriate to the environmental risk of the discharge.

Results of the statistical evaluation indicate the effluent is similar in composition to local drinking water (Columbia River water) with a little chloroform from the chlorinating process and some added chloride and iron (primarily particulate). Based on effluent data for four consecutive years, the probability of exceeding permit limits under normal operating conditions is less than one in a million, except for iron. Maximum monthly average concentrations of iron were exceeded twice for total iron.

Random transient increases in total iron and chloride occurred during the evaluation period. The iron transients are attributed to periodic flushing of rust particles from aging water and wastewater distribution and collection piping. The random spikes of chloride were due to ion-exchange column regeneration at the 200 Areas power plants that were shut down in 1998.

As a result of the 4-year period of effluent monitoring and data evaluation, the TEDF effluent composition and variability of the effluent waste stream are now well defined. Accordingly, a modified effluent monitoring program is proposed that is more tailored to contemporary 200 Area wastewater conditions. The low detection frequency for several permit constituents, the small number of actual permit limit exceedances and low exceedance probabilities for detected constituents indicate a significant reduction in the number and/or type of routine measurements can be made with no risk to the environment. The approach or strategy relies on (1) the use of gross alpha and gross beta in lieu of isotope specific analyses, (2) elimination of analytes with a history of non-detects, and (3) reduction in frequency of sampling where appropriate. Implementation of the proposed changes to the discharge permit will result in a more efficient and cost-effective effluent monitoring program.

\section{Notice}

This report is based on the effluent data that was available through June 28, 1999. However, high iron, manganese, and chromium concentrations for a sample collected on June 21, 1999, were validated after this report was completed. It was determined that these results may not adequately represent the typical composition of the original sample due to the presence of particulate material in the sample (i.e., nonhomogeneous and highly variable). The excursions were the subject of a non-compliance report submitted to Washington State Department of Ecology (Ecology) on September 20, 1999. Therefore, the data set used for the statistical evaluation presented in this report did not include the anomalously high iron, manganese, and chromium concentrations that occurred on June 21, 1999. 



\section{Contents}

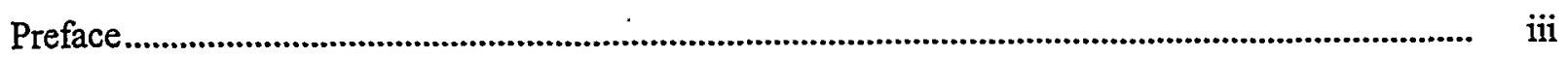

Summary

1.0 Introduction ..................................................................................................................

1.1 Background.............................................................................................................. 1.1

1.2 Objectives and Scope.................................................................................................. 1.1

2.0 Detections ........................................................................................................................ 2.1

3.0 Elevated Concentrations ...................................................................................................... 3.1

3.1 Iron ................................................................................................................... 3.1

3.2 Gross Alpha ........................................................................................................... 3.1

3.3 Chloride ........................................................................................................... 3.1

3.4 Filtered versus Unfiltered Metals ................................................................................ 3.2

4.0 Trends ................................................................................................................. 4.1

4.1 Seasonal Variation ..................................................................................................... 4.1

4.2 Random Spikes ........................................................................................................ 4.1

4.3 Steady or Stable Concentrations.................................................................................... 4.3

5.0 Summary of Statistical Results ............................................................................................ 5.1

5.1 Standard Summary Statistics ................................................................................... 5.1

5.2 Box and Whisker Plots ................................................................................................... 5.1

5.3 Exceedance Probability …………………………………................................................ 5.1

5.4 Comparison of Effluent with River Water.......................................................................... 5.3

6.0 Justification for Permit Modification ......................................................................................... 6.1

6.1 Analyte Deletions .................................................................................................... 6.1

6.1.1. Radioisotopes .................................................................................................... 6.1

6.1.2 WTPH-G/Oil and Grease........................................................................... 6.2

vii 


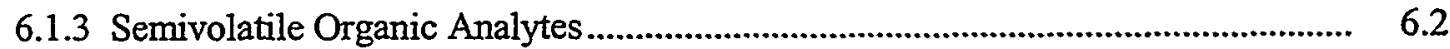

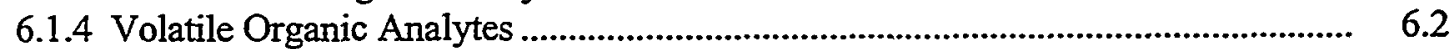

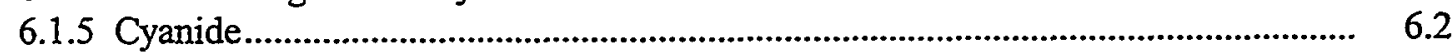

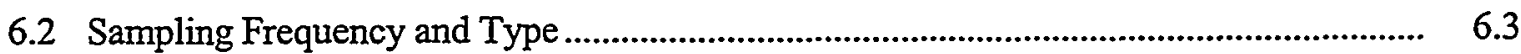

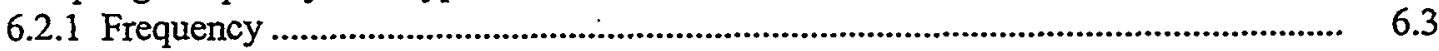

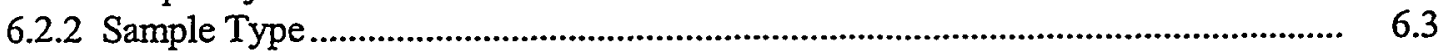

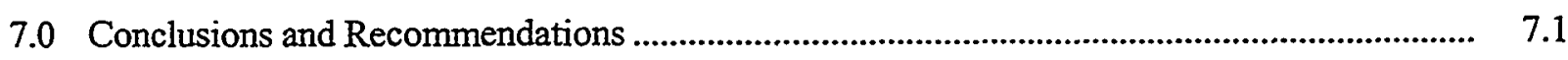

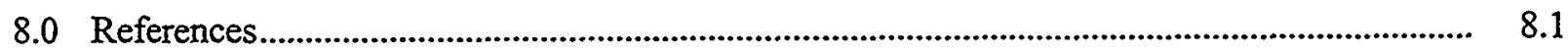

Appendix A - Statistical Data Tables ................................................................................... A.1

Appendix B - Graphical Display of Effluent Monitoring Data ................................................. B.1 


\section{Figures}

1 . Schematic Diagram of the Effluent Collection System for TEDF ............................................ 1.2

2a TEDF Effluent Monitoring Result - Iron Monthly Averages ..................................................... 3.2

2b TEDF Effluent Variability - Iron Grab and Composite Sample Results ..................................... 3.2

3a TEDF Effluent Variability - Chloride Grab and Composite Sample Results ............................. 4.2

3b TEDF Effluent Monitoring Result - Chloride Monthly Averages ............................................... 4.2

4 TEDF Continuous Monitoring Result - Daily Average Flow Rate................................................ • 4.3

\section{Tables}

1 Summary of Permit Requirements and Combined Monitoring Program Used During July 1995 through June 1996

2 Analytical Method and Detection Level Summary for Detected Constituents Analyzed for TEDF Effluent Variability Study ............................................................................................ 2.4

3 Detection Frequency Summary for the Constituents Analyzed for the TEDF Effluent Variability Study

4 Seasonal Effect and Variability Summary for TEDF Detected Constituents

5a Concentrations of Selected Radionuclide Concentrations Measured in Columbia River Water Compared to Concentrations Measured in the 200 Area TEDF Effluent

$5 \mathrm{~b}$ Concentrations of Selected Chemical Constituent Concentrations Measured in Columbia River Water Compared to Concentrations Measured in the 200 Area TEDF Effluent.

5c Concentrations of Gross Alpha and Gross Beta Concentrations Measured in Columbia River Water Compared to Concentrations Measured in the 200 Area TEDF Effluent for Calendar Years 1995 to 1997.

6a Current and Proposed Effluent Monitoring Plan for the 200 Area TEDF

$6 \mathrm{~b}$ Summary of TEDF Monitoring Results Based on Effluent Data Collected from July 1995 through June 1999. 


\subsection{Introduction}

\subsection{Background}

The 200 Area Treated Effluent Disposal Facility (TEDF) consists of a pair of infiltration basins that receive wastewater originating from the 200 West and 200 East Areas of the Hanford Site (Figure 1). TEDF has been in operation since 1995 and is regulated by State Waste Discharge Permit ST 4502 (Ecology 1995) under the authority of Chapter 90.48 Revised Code of Washington (RCW) and Washington Administrative Code (WAC) Chapter 173-216. The permit stipulates monitoring requirements for effluent (or end-of-pipe) discharges and groundwater monitoring for TEDF. Groundwater monitoring began in 1992 prior to TEDF construction. Routine effluent monitoring in accordance with the permit requirements began in late April 1995 when the facility began operations.

The State Waste Discharge Permit ST 4502 included a special permit condition (S.6). This condition specified a statistical study of the variability of permitted constituents in the effluent from TEDF during its first year of operation. The study was designed to (1) demonstrate compliance with the waste discharge permit; (2) determine the variability of all constituents in the effluent that have enforcement limits, early warning values, and monitoring requirements (WHC 1995); and (3) determine if concentrations of permitted constituents vary with season. Additional and more frequent sampling was conducted for the effluent variability study. Statistical evaluation results were provided in Chou and Johnson (1996). Parts of the original first year sampling and analysis plan (WHC 1995) were continued with routine monitoring required up to the present time.

\subsection{Objectives and Scope}

This report updates the original study of effluent variability (Chou and Johnson 1996) for TEDF. A major objective of this document is to provide supporting justification for modifying permit ST4502, Section S.9 regarding effluent monitoring and to propose a new monitoring regime in accordance with Section S.6. The first 4 years of effluent monitoring data were evaluated and used to statistically justify changes in permit effluent monitoring conditions. The permit modifications will be used to regulate and monitor TEDF at a level appropriate to the environmental risk of the discharge. Numerical and graphical results of the updated statistical evaluation are provided in Appendix A and B. The results are summarized and discussed in the following sections followed by recommendations for modifications to the existing monitoring program. 

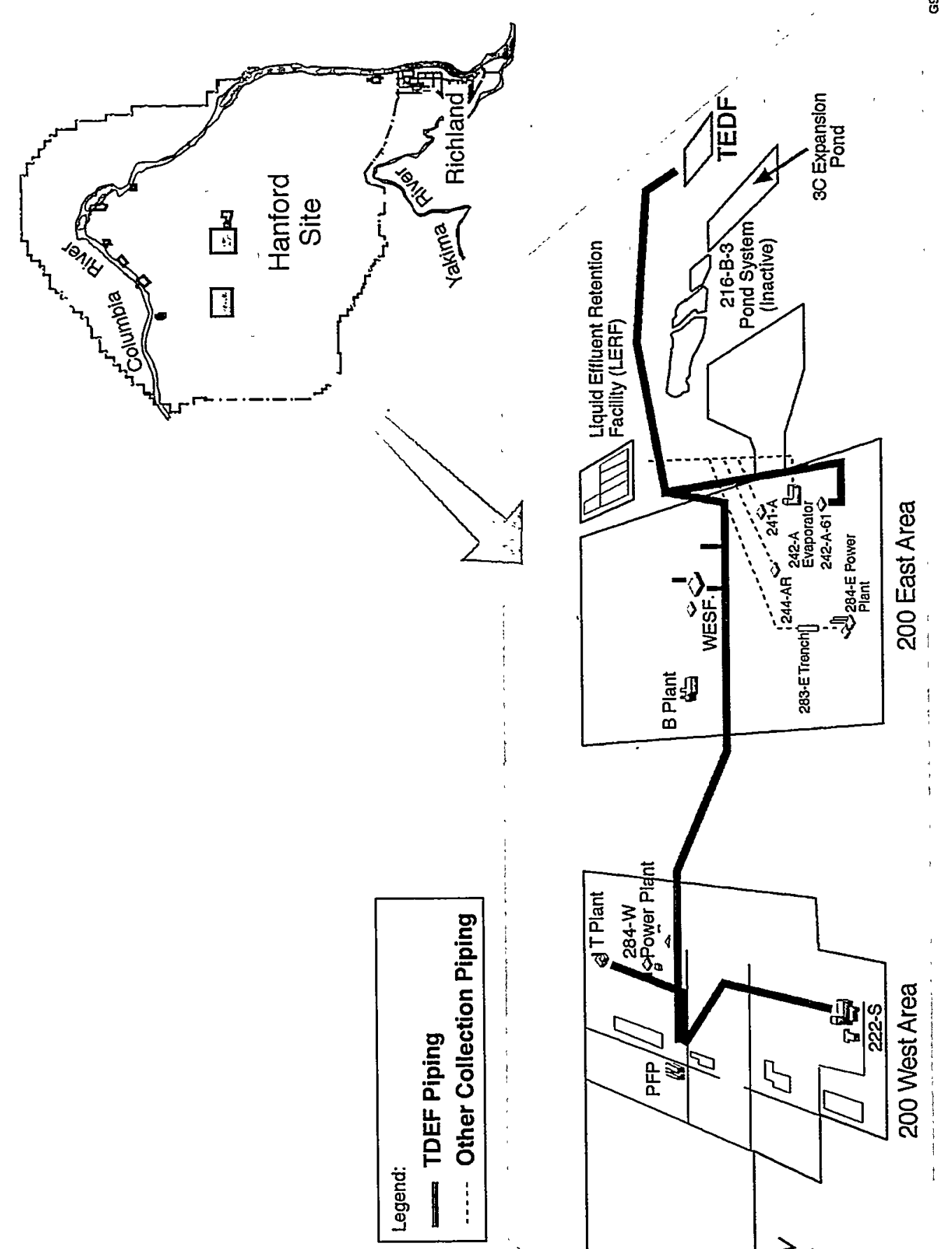


\subsection{Detections}

The sampling schedule and analyte list for the first year of TEDF operation (July 1995 through June 1996) are summarized in Table 1. More frequent sampling was conducted during this period to evaluate variability in analyte concentrations over time and to determine facility operational factors that might contribute to waste stream variability. At the conclusion of data collection for the variability analysis, sampling no longer included the samples and analytes required solely for the variability study. In subsequent years, only the routine monitoring indicated in Table 1 is required for permit compliance.

Continuous monitoring for $\mathrm{pH}_{\text {; }}$ specific conductivity, and flow are also part of the overall monitoring program. The continuous measurements allow general water quality to be tracked on a day-to-day or real-time basis and indicate major changes in the effluent.

Current analytical methods and detection levels for constituents of interest are shown in Table 2. A detection frequency summary of all results to date (listed by years) is provided in Table 3 . The detection limits improved for several constituents during the four-year period (e.g., arsenic, cadmium, chromium, lead, and radium-226) and account for the implied increase in detections. Even though the frequencies of detection for these constituents increased numerically, natural levels in river water account for most of the detections, as discussed later (Section 5.4).

Supporting details of Table 3 (by seasons of the year) are presented in Appendix A (Table A-1). A description of Table 3 (by constituent group) follows.

Volatile Organics. Total trihalomethane was the only significant volatile organic analyte (VOA) detected. Chloroform was the dominant trihalomethane with only occasional detections of bromodichloromethane. In addition, methylene chloride, a common laboratory contaminant, was reported as a detected constituent in 6 of the 237 samples analyzed for VOAs during the 4-year period. As noted in the previous variability study report (Chou and Johnson 1996), the trihalomethanes seem to be highest during the spring and summer. This seasonal factor is attributed to the increase in natural organics in river water that react with the chlorine to form the trihalomethanes. (Chlorine is added to river water from the $100 \mathrm{~B}$ Area at the water treatment plant to produce sanitary and drinking water for use in the 200 Areas.)

Semi-Volatiles. Except for the initial period of the variability study, phenol and bis (2-ethylhexyl) phthalate were analyzed in only the composite samples (see Table 1). Phenol was not detected during the 4-year period. The highest detection frequency (17\% in grab samples) for bis (2-ethylhexyl) phthalate . occurred during the first year of operation. The detection frequency for this constituent has declined in subsequent years to only a few percent (e.g., $2 \%$ or 1 detection in a total of 48 samples analyzed during the period from July 1998 to June 1999). 
Table 1. Summary of Permit Requirements and Combined Monitoring Program Used During July 1995 through June 1996

\begin{tabular}{|c|c|c|c|c|}
\hline \multirow[b]{2}{*}{ Parameter } & \multicolumn{2}{|c|}{ Permit Requirements } & \multicolumn{2}{|c|}{ Combined Monitoring Program $^{(\mathrm{a})}$} \\
\hline & Routine & Variability Study & Summer-Winter ${ }^{(b)}$ & Fall-Spring $^{(\mathrm{c})}$ \\
\hline \multicolumn{5}{|c|}{ Volatile Organic Compounds } \\
\hline \begin{tabular}{|l} 
Carbon tetrachloride \\
Methylene chloride \\
1,1,1,-Trichloroethane \\
Total trihalomethanes: \\
Bromoform \\
Bromodichloromethane \\
Chloroform \\
Dibromochloromethane \\
\end{tabular} & Grab 4/month & Random grab 10/month & Random grab $1 / 3$ days & Random grab 1/week \\
\hline \multicolumn{5}{|c|}{ Semivolatile Organic Compounds } \\
\hline $\begin{array}{l}\text { Bis(2-ethylhexyl)phthalate } \\
\text { Phenol }\end{array}$ & Composite $^{(d)} 4 /$ month & Composite $4 /$ month & $\begin{array}{l}\text { Random grab } 1 / 3 \text { days } \\
\text { Composite } 1 / \text { week }\end{array}$ & $\begin{array}{l}\text { Random grab 1/week } \\
\text { Composite } 1 / \text { week }\end{array}$ \\
\hline \multicolumn{5}{|c|}{ Total Metals } \\
\hline $\begin{array}{l}\text { Arsenic } \\
\text { Cadmium } \\
\text { Chromium } \\
\text { Lead } \\
\text { Mercury } \\
\end{array}$ & Composite $4 /$ month & $\begin{array}{l}\text { Random grab } 10 / \text { month } \\
\text { Compósite } 4 / \text { month }\end{array}$ & $\begin{array}{l}\text { Random grab } 1 / 3 \text { days } \\
\text { Composite } 1 / \text { week }\end{array}$ & $\begin{array}{l}\text { Random grab } 1 / \text { week } \\
\text { Composite } 1 / \text { week }\end{array}$ \\
\hline $\begin{array}{l}\text { Iron } \\
\text { Manganese } \\
\end{array}$ & Composite $1 /$ month & $\begin{array}{l}\text { Random grab } 10 / \text { month } \\
\text { Composite } 4 / \text { month }\end{array}$ & $\begin{array}{l}\text { Random grab } 1 / 3 \text { days } \\
\text { Composite } 1 / \text { week }\end{array}$ & $\begin{array}{l}\text { Random grab } 1 / \text { week } \\
\text { Composite } 1 / \text { week }\end{array}$ \\
\hline \multicolumn{5}{|c|}{ Anions } \\
\hline $\begin{array}{l}\text { Chloride } \\
\text { Nitrate } \\
\text { Sulfate } \\
\end{array}$ & Composite $1 /$ month & Composite $4 /$ month & $\begin{array}{l}\text { Random grab } 1 / 3 \text { days } \\
\text { Composite } 1 / \text { week }\end{array}$ & $\begin{array}{l}\text { Random grab 1/week } \\
\text { Composite } 1 / \text { week }\end{array}$ \\
\hline \multicolumn{5}{|c|}{ Other Analyses } \\
\hline Cyanide & Grab 4/month & -- & Random grab 1/week & Random grab 1/week \\
\hline WTPH-G & Grab $1 /$ month & -- & Random grab $1 /$ month & Random grab $1 /$ month \\
\hline Oil and grease & Grab $1 /$ month & Composite $4 /$ month & $\begin{array}{l}\text { Random grab } 1 / \text { month } \\
\text { Composite } 1 / \text { week }\end{array}$ & Random grab $1 /$ month \\
\hline Total dissolved solids & Composite $1 /$ month & $\cdots$ & Composite $1 /$ month & Composite $1 /$ month \\
\hline
\end{tabular}


Table 1. (contd)

\begin{tabular}{|c|c|c|c|c|}
\hline \multirow[b]{2}{*}{ Parameter } & \multicolumn{2}{|c|}{ Permit Requirements } & \multicolumn{2}{|c|}{ Combined Monitoring Program ${ }^{(\mathrm{a})}$} \\
\hline & Routine & Variability Study & Summer-Winter ${ }^{(b)}$ & Fall-Spring ${ }^{(c)}$ \\
\hline $\begin{array}{l}\text { Gross alpha } \\
\text { Gross beta } \\
\text { Total radium (Radium-226 and Radium-228) } \\
\text { Radium-226 } \\
\end{array}$ & Grab $1 /$ month & $\ldots$ & Random grab 1 /month & Random grab $1 /$ month \\
\hline \multicolumn{5}{|c|}{ In-Line Monltoring } \\
\hline $\begin{array}{l}\text { Flow } \\
\text { Specific conductivity } \\
\text { pH }\end{array}$ & Continuous & Continuous & Continuous & Continuous \\
\hline $\begin{array}{l}\text { (a) Combined monitoring program includes b } \\
\text { (b) Summer = July through September. } \\
\text { Winter = December through February. } \\
\text { (c) Fall = October through November. } \\
\text { Spring = March through June. } \\
\text { (d) Composite = a flow proportional composi }\end{array}$ & th the variability & $\begin{array}{l}\text { routine monitoring } \\
\text { h-hour period. }\end{array}$ & med from July 1995 & h June 1996). \\
\hline
\end{tabular}


Table 2. Analytical Method and Detection Level Summary for Detected Constituents Analyzed for TEDF Effluent Variability Study

\begin{tabular}{|c|c|c|}
\hline Parameter & Analytical Method & $\begin{array}{l}\text { Detection } \\
\text { Level } \\
\end{array}$ \\
\hline \multicolumn{3}{|c|}{ Volatile Organic Compound: } \\
\hline $\begin{array}{l}\text { Carbon tetrachloride }(\mu \mathrm{g} / \mathrm{L}) \\
\text { Methylene chloride }(\mu \mathrm{g} / \mathrm{L}) \\
\text { 1,1,1-trichloroethane }(\mu \mathrm{g} / \mathrm{L}) \\
\text { Total trihalomethanes: }(\mu \mathrm{g} / \mathrm{L}) \\
\text { Bromoform }(\mu \mathrm{g} / \mathrm{L}) \\
\text { Bromodichloromethane }(\mu \mathrm{g} / \mathrm{L}) \\
\text { Chloroform }(\mu \mathrm{g} / \mathrm{L}) \\
\text { Dibromochloromethane }(\mu \mathrm{g} / \mathrm{L})\end{array}$ & $\begin{array}{l}\text { SW-846 8260A } \\
\text { SW-846 8260A } \\
\text { SW-846 8260A } \\
\text { SW-846 8260A } \\
\text { SW-846 8260A } \\
\text { SW-846 8260A } \\
\text { SW-846 8260A } \\
\text { SW-846 8260A }\end{array}$ & $\begin{array}{l}0.7 \\
1.1 \\
0.6 \\
1.2 \\
1.9 \\
1.2 \\
0.9 \\
1.6\end{array}$ \\
\hline \multicolumn{3}{|c|}{ Semivolatile Organic Compound: } \\
\hline $\begin{array}{l}\text { Bis(2-ethylhexyl)phthalate }(\mu \mathrm{g} / \mathrm{L}) \\
\text { Phenol }(\mu \mathrm{g} / \mathrm{L})\end{array}$ & $\begin{array}{l}\text { SW-846 8270B } \\
\text { SW-846 8270B }\end{array}$ & $\begin{array}{c}3.5 \\
2 \\
\end{array}$ \\
\hline \multicolumn{3}{|c|}{ Total Metals: } \\
\hline $\begin{array}{l}\text { Arsenic }(\mu \mathrm{g} / \mathrm{L}) \\
\text { Cadmium }(\mu \mathrm{g} / \mathrm{L}) \\
\text { Chromium }(\mu \mathrm{g} / \mathrm{L}) \\
\text { Lead }(\mu \mathrm{g} / \mathrm{L}) \\
\text { Mercury }(\mu \mathrm{g} / \mathrm{L}) \\
\text { Iron }(\mu \mathrm{g} / \mathrm{L}) \\
\text { Manganese }(\mu \mathrm{g} / \mathrm{L})\end{array}$ & $\begin{array}{l}\text { EPA-600 200.8 } \\
\text { EPA-600 } 200.8 \\
\text { EPA-600 200.8 } \\
\text { EPA-600 200.8 } \\
\text { EPA-600 200.8 } \\
\text { SW-846.6010A } \\
\text { SW-846 6010A }\end{array}$ & $\begin{array}{c}0.4 \\
0.21 \\
0.6 \\
0.21 \\
0.2 \\
6.6 \\
5\end{array}$ \\
\hline \multicolumn{3}{|c|}{ Anions: } \\
\hline $\begin{array}{l}\text { Chloride }(\mu \mathrm{g} / \mathrm{L}) \\
\text { Nitrate }(\text { as } \mathrm{N})(\mu \mathrm{g} / \mathrm{L}) \\
\text { Sulfate }(\mu \mathrm{g} / \mathrm{L})\end{array}$ & $\begin{array}{l}\text { EPA-600 } 300.0 \\
\text { EPA-600 } 300.0 \\
\text { EPA-600 } 300.0 \\
\end{array}$ & $\begin{array}{c}420 \\
20 \\
500 \\
\end{array}$ \\
\hline \multicolumn{3}{|c|}{ Other Analyses: } \\
\hline $\begin{array}{l}\text { Cyanide }(\mu \mathrm{g} / \mathrm{L}) \\
\text { WTPH-G }(\mu \mathrm{g} / \mathrm{L}) \\
\text { Oil and grease }(\mu \mathrm{g} / \mathrm{L}) \\
\text { Total dissolved solids }(\mu \mathrm{g} / \mathrm{L}) \\
\end{array}$ & $\begin{array}{l}\text { EPA-600 335.3 } \\
\text { WTPH-G (WA), } \\
\text { SW-846 9070 } \\
\text { EPA-600 } 160.1 \\
\end{array}$ & $\begin{array}{c}5 \\
50 \\
5,000 \\
1,000 \\
\end{array}$ \\
\hline Gross alpha $(\mathrm{pCi} / \mathrm{L})$ & Laboratory Specific & 1.8 \\
\hline Gross beta $(\mathrm{pCi} / \mathrm{L})$ & Laboratory Specific & 1.8 \\
\hline $\begin{array}{l}\text { Total radium, Radium-226 and } \\
\text { Radium-228 (pCi/L) }\end{array}$ & Laboratory Specific & 5 \\
\hline Radium-226 (pCi/L) & Laboratory Specific & 1 \\
\hline
\end{tabular}


Table 3. Detection Frequency Summary ${ }^{(a)}$ for the Constituents Analyzed for the TEDF Effluent Variability Study

\begin{tabular}{|c|c|c|c|c|c|}
\hline \multirow[b]{2}{*}{ Parameter } & \multicolumn{2}{|l|}{. } & \multicolumn{3}{|c|}{ ly through June } \\
\hline & $\begin{array}{c}\text { Year } 1 \\
(95-96) \\
\end{array}$ & $\begin{array}{c}\text { Year } 2 \\
(96-97) \\
\end{array}$ & $\begin{array}{c}\text { Year 3 } \\
(97-98)\end{array}$ & $\begin{array}{c}\text { Year } 4 \\
(98-99)\end{array}$ & $\begin{array}{c}\text { Total } \\
(95-99)\end{array}$ \\
\hline \multicolumn{6}{|c|}{ Volatile Organic Compound ${ }^{(\mathfrak{b})}$} \\
\hline Carbon tetrachloride & $0 / 86$ & $0 / 52$ & $0 / 50$ & $0 / 49$ & $0 / 237$ \\
\hline Methylene chloride & $0 / 86$ & $0 / 52$ & $1 / 50$ & $5 / 49$ & $6 / 237$ \\
\hline 1,1,1-trichloroethane & $0 / 86$ & $0 / 52$ & $0 / 50$ & $0 / 49$ & $0 / 237$ \\
\hline Total trihalomethanes: & $86 / 86$ & $35 / 52$ & $24 / 50$ & $39 / 49$ & $184 / 237$ \\
\hline Bromoform & $0 / 86$ & $0 / 52$ & $0 / 50$ & $0 / 49$ & $0 / 237$ \\
\hline Bromodichloromethane & $19 / 86$ & $0 / 52$ & $0 / 50$ & $9 / 49$ & $28 / 237$ \\
\hline Chloroform & $\cdot 86 / 86$ & $36 / 52$ & $26 / 50$ & $45 / 49$ & $193 / 237$ \\
\hline Dibromochloromethane & $0 / 86$ & $0 / 52$ & $0 / 50$ & $0 / 49$ & $0 / 237$ \\
\hline \multicolumn{6}{|c|}{ Semivolatile Organic Compound } \\
\hline Bis(2-ethylhexyl)phthalate & & & & & \\
\hline Grab Sample & $15 / 87$ & - & - & $0 / 1$ & $15 / 88$ \\
\hline Composite Samples & $5 / 50$ & $3 / 52$ & $2 / 50$ & $1 / 48$ & $11 / 200$ \\
\hline \multicolumn{6}{|l|}{ Phenol } \\
\hline Grab Sample & $0 / 87$ & - & - & $0 / 1$ & $0 / 88$ \\
\hline Composite Sample & $0 / 50$ & $0 / 52$ & $0 / 50$ & $0 / 48$ & $0 / 200$ \\
\hline \multicolumn{6}{|c|}{ Total Metals } \\
\hline \multicolumn{6}{|l|}{ Arsenic } \\
\hline Crab Sample & $3 / 87$ & - & - & $1 / 1$ & $4 / 88$ \\
\hline Composite Sample & $4 / 51$ & $17 / 52$ & $44 / 50$ & $46 / 48$ & $111 / 201$ \\
\hline Cadmium & & & & & \\
\hline Grab Sample & $0 / 87$ & - & - & $0 / 1$ & $0 / 88$ \\
\hline Composite Sample & $1 / 51$ & $5 / 52$ & $5 / 50$ & $8 / 48$ & $19 / 201$ \\
\hline \multicolumn{6}{|l|}{ Chromium } \\
\hline Grab Sample & $8 / 87$ & - & - & $1 / 1$ & $9 / 88$ \\
\hline Composite Sample & $2 / 51$ & $11 / 52$ & $17 / 50$ & $21 / 48$ & $51 / 201$ \\
\hline \multicolumn{6}{|l|}{ Lead } \\
\hline Grab Sample & $11 / 87$ & -- & -- & $1 / 1$ & $12 / 88$ \\
\hline Composite Sample & $9 / 51$ & $30 / 52$ & $22 / 50$ & $38 / 48$ & 99/201 \\
\hline \multicolumn{6}{|l|}{ Mercury } \\
\hline Grab Sample & $21 / 87$ & - & - & $0 / 1$ & $21 / 88$ \\
\hline Composite Sample & $8 / 51$ & $11 / 52$ & $3 / 50$ & $4 / 48$ & $26 / 201$ \\
\hline \multicolumn{6}{|l|}{ Iron. } \\
\hline Grab Sample & $87 / 87$ & - & - & $1 / 1$ & $88 / 88$ \\
\hline Composite Sample & $51 / 51$ & $54 / 54$ & $50 / 50^{\circ}$ & $48 / 48$ & $203 / 203$ \\
\hline Manganese & & & & & \\
\hline Grab Sample & $50 / 87$ & - & - & $1 / 1$ & $51 / 88$ \\
\hline Composite Sample & $23 / 51$ & $15 / 54$ & $12 / 50$ & $26 / 48$ & $76 / 203$ \\
\hline
\end{tabular}


Table 3. (contd)

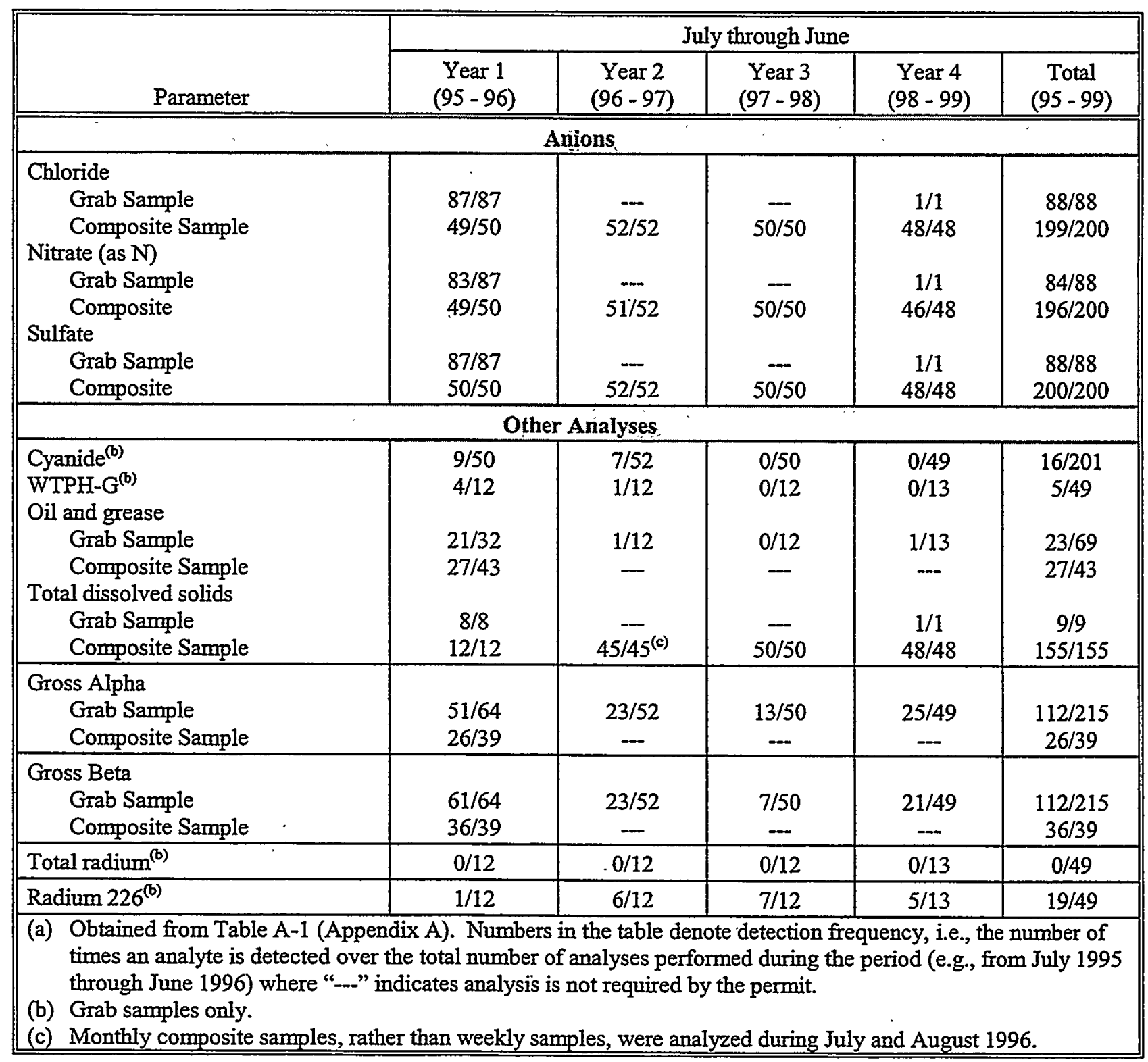

Metals. Metals were analyzed in both grab and composite samples during the first year. Based on the initial findings, composites were deemed adequate for subsequent monitoring purposes. The most commonly detected metals were iron, manganese and lead. Also, the detection frequencies of arsenic, chromium and lead have increased. As noted previously, this apparent increase in detection frequencies is attributed to the use of lower detection limits associated with a change in analytical methods from GFAA to ICP/MS. While arsenic, chromium and lead detection frequencies increased, the levels are comparable to concentrations reported for Columbia River water (see Section 5.4). 
Anions. Chloride, nitrate, and sulfate are consistently detected because these common anions are found in the makeup water (Columbia River water). Likewise, total dissolved solids are always detected. Nitrate and most of the sulfate can be accounted for by river water whereas chloride is higher than average river water due to contributor inputs (see river water comparison in Section 5.4).

Other analyses (cyanide, WTPH-G, oil, and grease). Moderately frequent detections of these constituents occurred during the first and second year $(1995-96,1997)$ and not at all during the most recent two years (1998 and 1999).

Gross alpha and gross beta. These radionuclide indicators were frequently detected over the 4-year period although less so during the most recent two years. The detections are in part due to naturally occurring radionuclides present in Columbia River and due to occasional inputs from contributors.

Radium-226. No detections of total radium (the sum of radium-226 and radium-228) and only occasional detections of radium-226 were reported for the 4-year period. The detection frequency of radium-226 has increased during the last 3 years. This is attributed to the dramatic lowering of the detection limit from $1 \mathrm{pCi} / \mathrm{L}$ to less than $0.05 \mathrm{pCi} / \mathrm{L}$ after year one. Even though the detection frequency increased after year one, the maximum radium-226 concentration reported was only $0.14 \mathrm{pCi} / \mathrm{L}$ (sample date, October 8,1997 ). This is consistent with previously reported radium-226 concentrations in Columbia River water (Table 5a). 


\subsection{Elevated Concentrations}

Elevated concentrations of a few constituents exceeded either drinking water standards or, in only two cases, the permit limits. The effluent quality enforcement limits are based on maximum composite sample monthly averages for the analytes of interest. There are also daily maximum allowable limits for chloride and nitrate as well as a maximum monthly average limit for these two anions. The monthly average concentrations of permit required analyte measurements over the four-year period are tabulated in Table A-2 (Appendix A). It should be noted in calculating these averages that measurements below the practical quantification levels (PQL) were not replaced by zero as required for the Discharge Monitoring Report (DMR). Exceedances and elevated concentrations are discussed in the following section.

\subsection{Iron}

The iron measurements are made on unfiltered (digested) samples. Thus this total iron result includes both dissolved iron and particulate iron. Maximum monthly average concentrations were exceeded twice for total iron ( $890 \mathrm{ppb}$ for April 1996 and $526 \mathrm{ppb}$ for January 1997 as compared to the enforcement limit of $258 \mathrm{ppb}$ ) (Figure 2a). The random transient increases in total iron (Figure 2b) are attributed to periodic flushing of rust particles from aging water and wastewater piping. Although high total iron concentrations and two exceedances occurred during the 4-year period, it is also noteworthy that the magnitude of the excursions in total iron concentration appears to have attenuated markedly since initial operation of TEDF (see Figure 2a). The contributors attribute this improvement to increased diligence and attention to operational factors. However, the iron transient occurrences are expected to continue to be a recurring issue as piping systems age. There are no plans to replace aging pipes to mitigate the sporadic release of particulate iron (presumably rust particles).

\subsection{Gross Alpha}

The permit sets no limit for gross alpha. The highest monthly average gross alpha concentration of $24.4 \mathrm{pCi} / \mathrm{L}$ occurred in January 1999. (Note: It was reported as $23.5 \mathrm{pCi} / \mathrm{L}$ in the DMR because in calculating the averages and variability, values below the PQL are not replaced by zeros.) This occurrence was attributed to breakthrough from an effluent treatment filter bed at the Plutonium Finishing Plant (PFP).

\subsection{Chloride}

In the 24-hour composite samples, the daily maximum concentration of chloride had no exceedances. While not a permit limit exceedance, one grab sample did have a concentration higher than the permit limit (Figure 3a). Most of the chloride excursions or spikes were due to ion-exchange column regeneration for the 200 Area Power House boilers. These sources have been eliminated and thus chloride concentrations have been reduced. The latter change is readily evident in a plot of the weekly chloride results over the 4-year period (see Figure 3a). Both the magnitude and frequency of concentration excursions have declined significantly since mid-1998 (Figures $3 \mathrm{a}$ and $3 \mathrm{~b}$ ). 


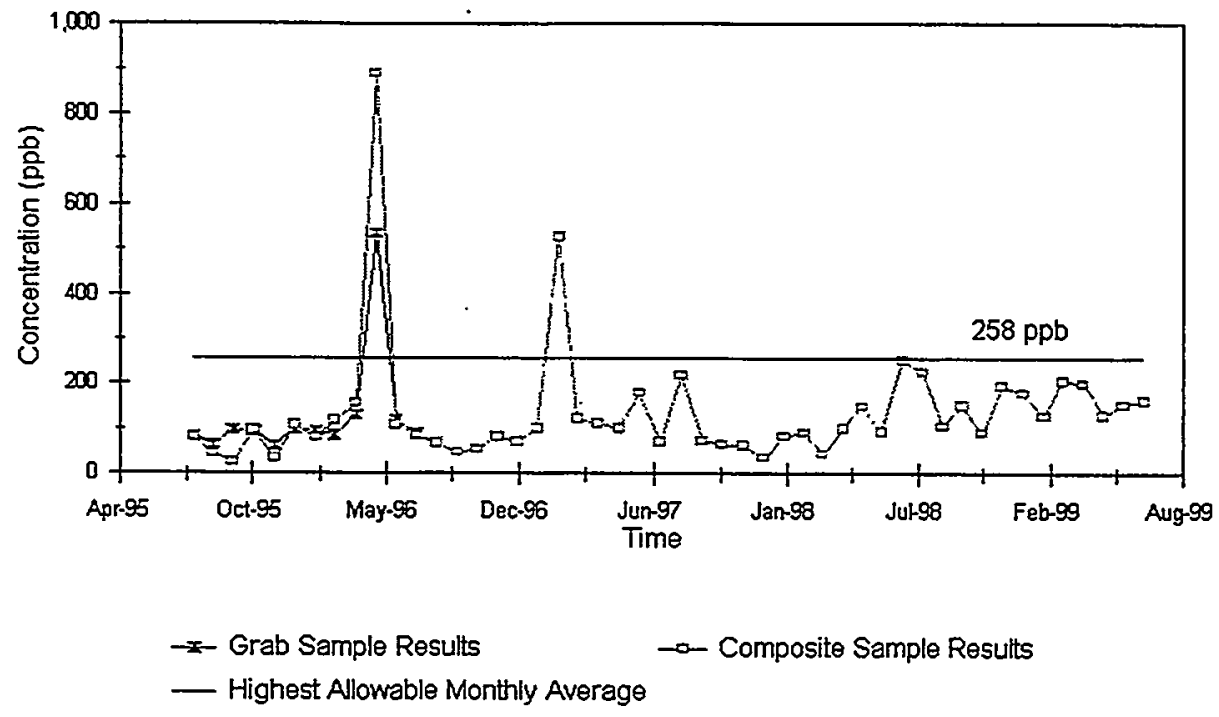

Figure 2a. TEDF Effluent Monitoring Result - Iron Monthly Averages

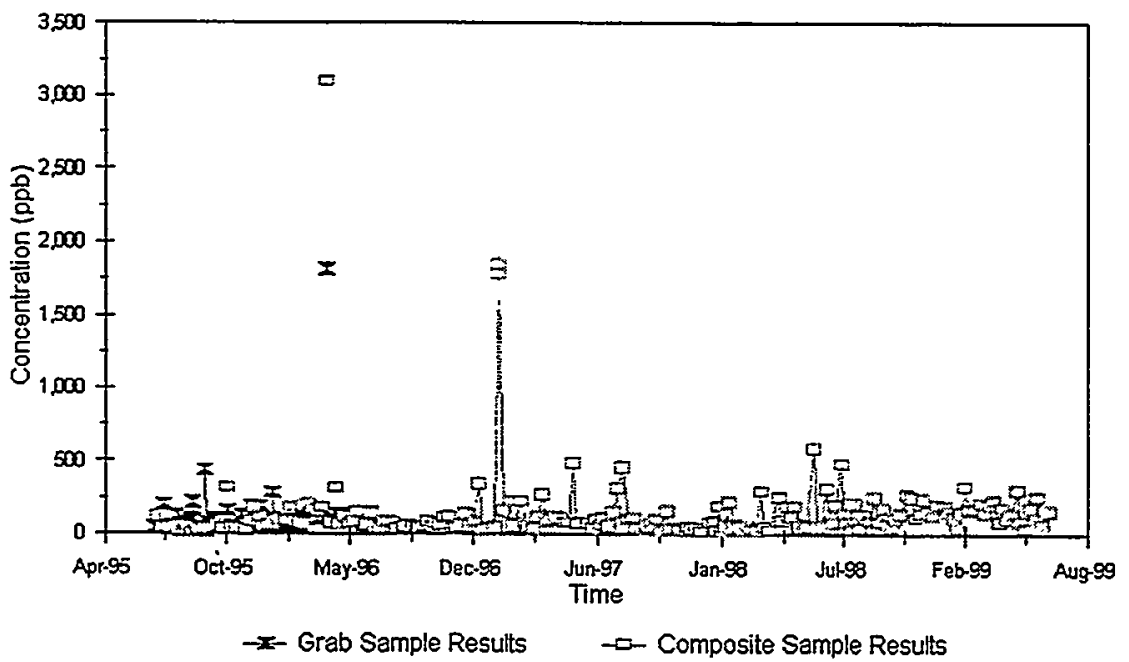

Figure 2b. TEDF Effluent Variability - Iron Grab and Composite Sample Results

\subsection{Filtered versus Unfiltered Metals}

The periodic iron spikes are most likely due to a particulate phase which is insoluble at $\mathrm{pH} 2$ (acidity of preserved sample). For example, based on both filtered and unfiltered results for composite samples collected on April 7, 1996, and January 1, 1997 (dates when total or unfiltered iron was 3,100 and $1,780 \mu \mathrm{g} / \mathrm{L}$, respectively), nearly all (>97\%) of the iron was particulate (iron that passed through an 0.45 micron filter was 101 and $36 \mu \mathrm{g} / \mathrm{L}$, respectively). The particulates in the unfiltered samples had to be "digested" in strong acid prior to analysis for total iron. Rust particles from old distribution lines that are periodically flushed are suspected to be the primary source for the particulate iron. 


\subsection{Trends}

Time series trend plots of detected constituents are included in Appendix B. These plots indicate three general patterns:

- cyclic or seasonal variations

- random spike occurrences

- continuous or non-varying concentrations.

\subsection{Seasonal Variation}

Total trihalomethane and chloroform exhibit concentration maxima during the spring and summer months. This trend was noted in the initial effluent variability report (Chou and Johnson 1996). The cause was attributed to treatment of raw water from the Columbia River with chlorine in the water treatment plant. The chlorine reacts with natural dissolved organic matter in the river water to produce chloroform as a byproduct of the chlorination process. During the spring and summer dissolved organic matter typically increases along with increased phytoplankton densities. This produces increased amounts of chloroform. As noted in Chou and Johnson (1996), chloroform production is well known in municipal drinking water supplies where the raw water is drawn from lakes or rivers. It is noteworthy that higher concentrations of chloroform occur in drinking water supplies (nationally as well as at Hanford) than were observed in the TEDF effluent.

Nitrate also seems to exhibit a seasonal trend. For example, concentrations appear to be lower in summer and fall. The decrease in nitrate could be related to increased phytoplankton production (i.e., depletion of nitrate due to increased phytoplankton growth), as suggested in Chou and Johnson (1996).

\subsection{Random Spikes}

Iron, manganese, and lead exhibit random concentration spikes that seem to occur at the same time. Arsenic also exhibits random concentration spikes, but these do not coincide with iron, manganese and lead. Chromium exhibits a random spike pattern that does not seem to coincide with any of the other metals. As previously noted (Chou and Johnson 1996), the iron excursions probably occur as primarily particulate phases (rust particles). It is not known if the other metals that seem to coincide with iron spikes (e.g., manganese and lead) are also primarily particulate in nature.

Chloride also exhibits random spike occurrences. This feature was previously noted in the initial variability study (Chou and Johnson 1996) and was attributed to regeneration of water softener resin columns. However, the total amount of chloride discharged decreased considerably after mid-1998 (see Figures $3 \mathrm{a}$ and $3 \mathrm{~b}$ ) because the aging 200 Areas power plants were shut down and replaced with five high-efficiency "package" boilers. Thus chloride concentrations in TEDF effluent should be greatly diminished in the future. 


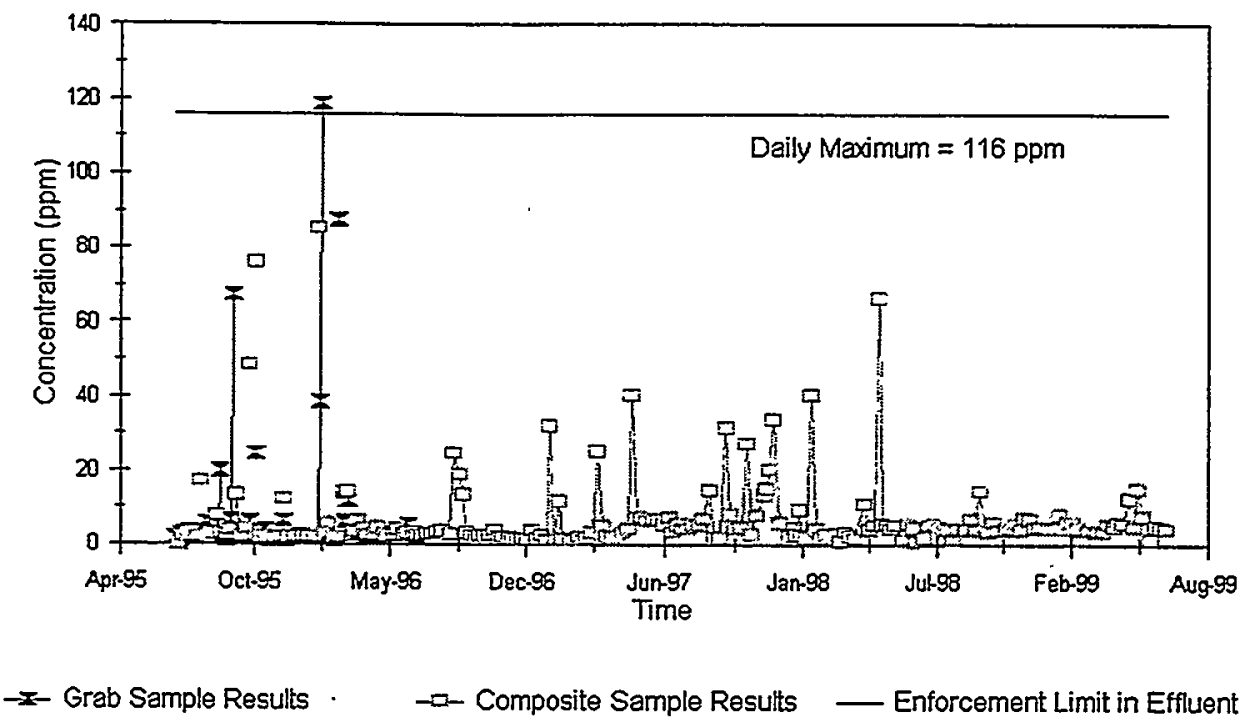

Figure 3a. TEDF Effluent Variability - Chloride Grab and Composite Sample Results

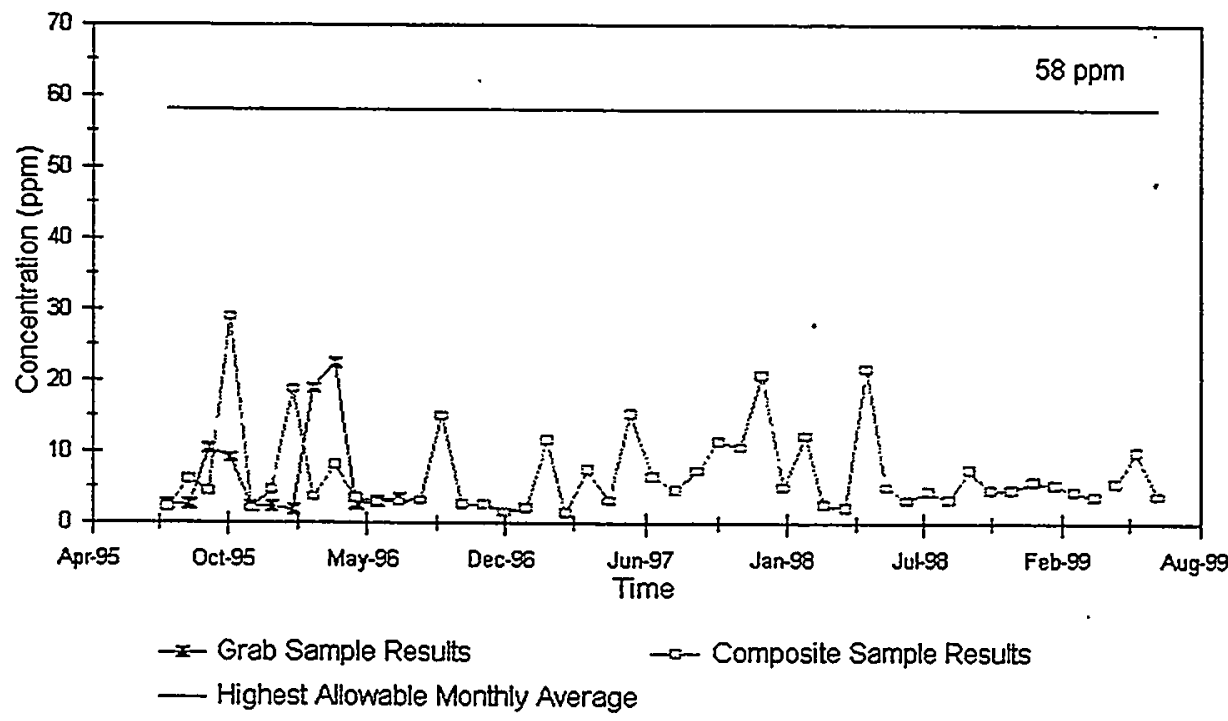

Figure 3b. TEDF Effluent Monitoring Result - Chloride Monthly Averages

Also, beginning in late 1997, the effluent flow rate shifted from a somewhat steady rate to more or less random fluctuations that approach or exceed 3,000 gpm for a few days or a week or two in duration for each event (Figure 4). These occurrences do not seem to coincide with either random increases in average metal or chloride concentrations discussed above. The dramatic change in effluent flow rate reflects operation of the 242-A Evaporator for short campaigns. This will be a common operational event for years into the future as Hanford Site cleanup continues. The primary effect of the periodic high-flow 


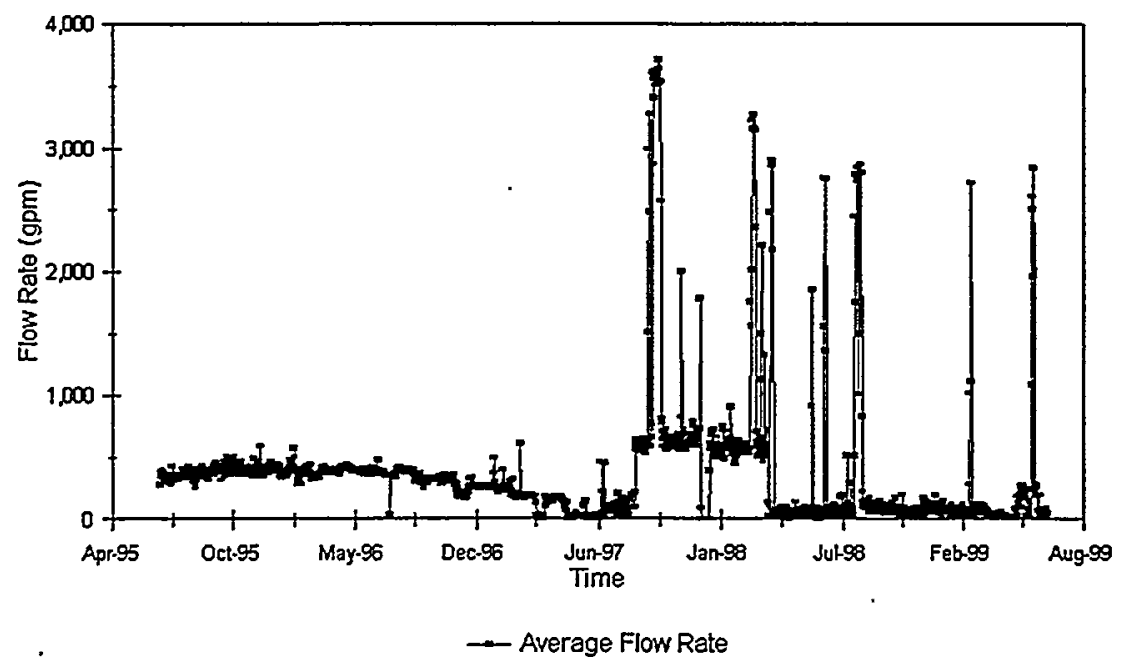

Figure 4. TEDF Continuous Monitoring Result - Daily Average Flow Rate

periods will be to produce an effluent that is essentially Columbia River water (i.e., condenser cooling water consisting of untreated Columbia River water from the 242-A Evaporator).

\subsection{Steady or Stable Concentrations}

Except for a short-term spike in gross beta in 1995, and one for gross alpha (which included some gross beta) in 1999, these two indicators exhibit relatively constant concentrations over time (see Appendix B) and are both similar to (but slightly higher) than gross alpha and gross beta concentrations reported for Columbia River water (see Section 5.4).

The average concentration of sulfate is somewhat higher than reported for the Columbia River (1998 annual average of $\sim 9 \mathrm{mg} / \mathrm{L}$ in river water versus $16 \mathrm{mg} / \mathrm{L}$ in effluent, see Section 5.4). There does not seem to be a significant contribution of sulfate from operations over the 4-year period, although concentrations did reach as high as $25 \mathrm{mg} / \mathrm{L}$ in April 1999 and then declined. The small addition of sulfate is due to the use of sulfuric acid to neutralize wastewater from 222-S prior to discharge. 


\subsection{Summary of Statistical Results}

A complete listing of results from the statistical evaluation and updates are provided in Appendix A and B. Statistical methods used are described in detail in the effluent variability study report (Chou and Johnson 1996). A summary of the salient features and findings of the statistical evaluation follows.

\subsection{Standard Summary Statistics}

The mean, standard deviation, 95\% upper confidence limit (UCL) on mean concentration and 95\% upper tolerance limit for detected analytes are provided (by season and by year) in the Appendix A (Table A-3). The variability is expressed as the coefficient of variation (CV) by season over the 4-year period is summarized in Table 4.

Chloride and iron have the largest variability of the detected analytes, as noted in the initial variability study. The high iron variability is attributed to random occurrences of particulate iron flushed from rusting cast iron pipe. The high chloride variability is due to the random disposal of ion exchange column regenerant. These transients were significantly reduced with closure of the 200 Area power plant facilities.

Sulfate exhibits the lowest CV. Except for two short-term releases previously discussed, gross beta and gross alpha exhibit relatively low variability.

\subsection{Box and Whisker Plots}

Box and whisker plots (Appendix B) of all detected analyte data for the 4-year period, segregated by season, provide a graphical indication of possible seasonal influences. Table 4 also provides a numerical summary of the same information.

Chloroform, nitrate and iron appear to vary seasonally. Chloroform concentration is highest in spring and summer (nitrate is highest in spring and winter), as previously discussed, and iron is highest in winter and spring. Gross alpha also appears to have a slight seasonal component with highest concentrations occurring in the spring and summer. No cause and effect relationship for the latter is evident at this time.

\subsection{Exceedance Probability}

The probability of exceeding a permit limit under normal operating conditions was calculated for each detected constituent. Results indicate there is a very low probability of exceeding any of the permit

limits for the detected constituents of interest (see Table A-4, Appendix A). Except for iron, the exceedance probabilities were all less than one in one million. Iron had an exceedance probability of four in one thousand. 
Table 4. Seasonal Effect and Variability Summary (July 1995 through June 1999) for TEDF Detected Constituents

\begin{tabular}{|c|c|c|c|c|c|}
\hline \multirow[b]{2}{*}{ Parameter } & \multicolumn{4}{|c|}{ Season } & \multirow[b]{2}{*}{ Overall $^{(e)}$} \\
\hline & Summer $^{(\mathrm{a})}$ & Fall $^{(b)}$ & Winter ${ }^{(c)}$ & Spring ${ }^{(d)}$ & \\
\hline \multicolumn{6}{|c|}{ Volatile Organic Compounds: Grab Sample Results } \\
\hline $\begin{array}{l}\text { Total trihalomethanes } \\
\text { Number of samples } \\
\text { Mean (ppb) } \\
\text { CV (\%) }\end{array}$ & $\begin{array}{l}38 \\
5.9 \\
67 \\
\end{array}$ & $\begin{array}{l}35 \\
2.6 \\
75 \\
\end{array}$ & $\begin{array}{l}48 \\
2.4 \\
92 \\
\end{array}$ & $\begin{array}{c}67 \\
4.6 \\
82\end{array}$ & $\begin{array}{l}178 \\
4.0 \\
79\end{array}$ \\
\hline $\begin{array}{l}\text { Chloroform } \\
\text { Number of samples } \\
\text { Mean (ppb) } \\
\text { CV (\%) }\end{array}$ & $\begin{array}{c}70 \\
8.1 \\
54\end{array}$ & $\begin{array}{l}33 \\
3.8 \\
75\end{array}$ & $\begin{array}{l}67 \\
3.1 \\
76\end{array}$ & $\begin{array}{l}67 \\
4.5 \\
86\end{array}$ & $\begin{array}{l}237 \\
5.1 \\
73\end{array}$ \\
\hline \multicolumn{6}{|c|}{ Total Metals: Composite Sample Results } \\
\hline $\begin{array}{l}\text { Iron }^{(\mathfrak{f})} \\
\text { Number of samples } \\
\text { Mean (ppb) } \\
\text { CV (\%) }\end{array}$ & $\begin{array}{c}51 \\
96.3 \\
102 \\
\end{array}$ & $\begin{array}{c}34 \\
83.5 \\
89 \\
\end{array}$ & $\begin{array}{c}51 \\
110.0 \\
71\end{array}$ & $\begin{array}{c}65 \\
137.1 \\
77\end{array}$ & $\begin{array}{c}201 \\
110.8 \\
85\end{array}$ \\
\hline $\begin{array}{l}\text { Manganese } \\
\text { Number of samples } \\
\text { Mean (ppb) } \\
\text { CV (\%) }\end{array}$ & $\begin{array}{l}51 \\
6.4 \\
71 \\
\end{array}$ & $\begin{array}{l}34 \\
6.1 \\
77 \\
\end{array}$ & $\begin{array}{l}51 \\
5.8 \\
44\end{array}$ & $\begin{array}{c}65 \\
7.1 \\
111 \\
\end{array}$ & $\begin{array}{c}201 \\
6.4 \\
76\end{array}$ \\
\hline $\begin{array}{l}\text { Arsenic }{ }^{(\mathrm{g})} \\
\text { Number of samples } \\
\text { Mean (ppb) } \\
\text { CV (\%) }\end{array}$ & $\begin{array}{l}38 \\
1.5 \\
89 \\
\end{array}$ & $\begin{array}{l}25 \\
0.8 \\
45\end{array}$ & $\begin{array}{l}38 \\
0.7 \\
80\end{array}$ & $\begin{array}{l}49 \\
0.7 \\
62\end{array}$ & $\begin{array}{l}150 \\
0.9 \\
69\end{array}$ \\
\hline \multicolumn{6}{|c|}{ Anions: Composite Sample Results } \\
\hline $\begin{array}{l}\text { Chloride } \\
\text { Number of samples } \\
\text { Mean (ppm) } \\
\text { CV (\%) }\end{array}$ & $\begin{array}{c}49 \\
6.0 \\
103 \\
\end{array}$ & $\begin{array}{l}34 \\
9.8 \\
1.60 \\
\end{array}$ & $\begin{array}{r}50 \\
6.6 \\
201 \\
\end{array}$ & $\begin{array}{l}66 \\
6.6 \\
144 \\
\end{array}$ & $\begin{array}{l}199 \\
7.0 \\
152\end{array}$ \\
\hline $\begin{array}{l}\text { Nitrate (as N) } \\
\text { Number of samples } \\
\text { Mean (ppb) } \\
\text { CV (\%) }\end{array}$ & $\begin{array}{c}50 \\
167.6 \\
62 \\
\end{array}$ & $\begin{array}{c}34 \\
147.9 \\
44 \\
\end{array}$ & $\begin{array}{c}50 \\
178.0 \\
29 \\
\end{array}$ & $\begin{array}{c}66 \\
201.4 \\
47\end{array}$ & $\begin{array}{c}200 \\
178.1 \\
46\end{array}$ \\
\hline $\begin{array}{l}\text { Sulfate } \\
\text { Number of samples } \\
\text { Mean (ppm) } \\
\text { CV (\%) }\end{array}$ & $\begin{array}{c}50 \\
13.6 \\
27 \\
\end{array}$ & $\begin{array}{c}34 \\
13.5 \\
27 \\
\end{array}$ & $\begin{array}{c}50 \\
13.1 \\
44\end{array}$ & $\begin{array}{c}66 \\
17.9 \\
46\end{array}$ & $\begin{array}{c}200 \\
14.9 \\
36\end{array}$ \\
\hline \multicolumn{6}{|c|}{ Other Analyses: Composite Sample Results } \\
\hline $\begin{array}{l}\text { Total Dissolved Solids } \\
\text { Number of samples } \\
\text { Mean (ppm) } \\
\text { CV (\%) }\end{array}$ & $\begin{array}{c}34 \\
80.9 \\
31 \\
\end{array}$ & $\begin{array}{c}27 \\
85.2 \\
25 \\
\end{array}$ & $\begin{array}{c}41 \\
78.3 \\
44\end{array}$ & $\begin{array}{c}53 \\
90.5 \\
30\end{array}$ & $\begin{array}{c}155 \\
84.2 \\
33 \\
\end{array}$ \\
\hline
\end{tabular}


Table 4. (contd)

\begin{tabular}{|c|c|c|c|c|c|}
\hline \multirow[b]{2}{*}{ Parameter } & \multicolumn{4}{|c|}{ Season } & \multirow[b]{2}{*}{ Overall $^{(e)}$} \\
\hline & Summer ${ }^{(a)}$ & Fall $^{(b)}$ & Winter ${ }^{(c)}$ & Spring $^{(\mathrm{d})}$ & \\
\hline \multicolumn{6}{|c|}{ Other Analyses: Composite Sample Results } \\
\hline $\begin{array}{l}\text { Total Dissolved Solids } \\
\text { Number of samples } \\
\text { Mean (ppm) } \\
\text { CV (\%) }\end{array}$ & $\begin{array}{c}34 \\
80.9 \\
31\end{array}$ & $\begin{array}{c}27 \\
85.2 \\
25\end{array}$ & $\begin{array}{c}41 \\
78.3 \\
44\end{array}$ & $\begin{array}{c}53 \\
90.5 \\
30\end{array}$ & $\begin{array}{c}155 \\
84.2 \\
33\end{array}$ \\
\hline \multicolumn{6}{|c|}{ Radionuclides: Grab Sample Results } \\
\hline $\begin{array}{l}\text { Gross Alpha }{ }^{(\mathrm{b})} \\
\text { Number of samples } \\
\text { Mean (pCi/L) } \\
\text { CV }(\%)\end{array}$ & $\begin{array}{c}47 \\
1.34 \\
68\end{array}$ & $\begin{array}{c}33 \\
1.06 \\
79\end{array}$ & $\begin{array}{c}63 \\
0.84 \\
58\end{array}$ & $\begin{array}{c}67 \\
2.05 \\
127\end{array}$ & $\begin{array}{c}210 \\
1.37 \\
83\end{array}$ \\
\hline $\begin{array}{l}\text { Gross Beta } \\
\text { Number of samples } \\
\text { Mean (ppb) } \\
\text { CV (\%) }\end{array}$ & $\begin{array}{c}38 \\
1.30 \\
40\end{array}$ & $\begin{array}{c}31 \\
1.58 \\
67\end{array}$ & $\begin{array}{c}68 \\
1.38 \\
85\end{array}$ & $\begin{array}{c}57 \\
1.54 \\
54\end{array}$ & $\begin{array}{c}194 \\
1.45 \\
62\end{array}$ \\
\hline $\begin{array}{l}\text { (a) Summer = July, Aug } \\
\text { (b) Fall = October and N } \\
\text { (c) Winter = December, } \\
\text { (d) Spring = March, Apr } \\
\text { (e) Overall = July } 1995 \\
\text { (f) Excluded data associ } \\
\text { (g) Data prior to July 1, } \\
\text { (h) Excluded data collec } \\
\text { (i) Excluded data collec }\end{array}$ & $\begin{array}{l}\text { eptember of } \\
\text { of } 1995,199 \\
\text { and February } \\
\text { nd June of } 19 \\
\text { ine } 1999 . \\
\text { iron excursio } \\
\text { not used (m } \\
\text { en January } 12 \\
\text { o October } 23\end{array}$ & $\begin{array}{l}1996,19 \\
7, \text { and } 19 \\
95,1996, \\
97,1998 \\
\text { pril } 7,19 \\
\text { Lot detec } \\
\text { and Fet } \\
\text { due to P }\end{array}$ & $\begin{array}{l}1998 . \\
\text { and } 1998 . \\
999 . \\
\text { January } 12 \\
17,1999 \text { du } \\
\text { release. }\end{array}$ & Prelease. & - \\
\hline
\end{tabular}

\subsection{Comparison of Effluent with River Water}

The mean \pm 2 times the standard error of the mean of available constituents of interest in Columbia River water below Priest Rapids Dam and at the Richland pump house were compared with effluent data for calendar year (CY) 1998 (Tables 5a and 5b). The river water data were collected quarterly in connection with the Hanford Site Environmental Surveillance Program. Data for CY 1998 were selected for the primary comparison because analytical detection limits used for effluent and river water were the most comparable for most constituents during 1998. An important difference, however, is that gross alpha and gross beta detection limits were the most comparable for the earlier years (gross alpha and beta detection limits for effluent measurements increased in 1998 and 1999). Therefore, a comparison of radiological data for the years prior to 1998 is provided in Table $5 \mathrm{c}$.

Tables $5 \mathrm{a}$ and $5 \mathrm{~b}$ illustrate that concentrations of constituents of interest in river water account for most of the observed concentrations of these constituents in effluent. For example, natural leyels in river water account for nearly all of the arsenic, nitrate, chromium, radium-226, uranium, gross alpha and gross beta in effluent. Deviations from this generalization are discussed as follows. 
Table 5a. Concentrations of Selected Radionuclide Concentrations Measured in Columbia River Water Compared to Concentrations Measured in the 200 Area TEDF Effluent

\begin{tabular}{|c|c|c|c|}
\hline \multirow[b]{2}{*}{ Parameter } & \multicolumn{3}{|c|}{ Calendar Year 1998} \\
\hline & $\begin{array}{l}\text { Number of } \\
\text { Samples }\end{array}$ & Maximum & Average $^{(a)}$ \\
\hline $\begin{array}{l}\text { Gross Alpha (pCi } \mathrm{L} \text { ) } \\
\text { Columbia River Water at Priest Rapid Dam }{ }^{(b)} \\
\text { Columbia River Water at Richland Pumphouse } \\
200 \text { Area TEDF Effluent }\end{array}$ & $\begin{array}{l}12 \\
12 \\
48\end{array}$ & $\begin{array}{c}1.6 \\
0.86 \\
4.8\end{array}$ & $\begin{array}{l}0.49 \pm 0.26 \\
0.47 \pm 0.12 \\
1.42 \pm 0.24\end{array}$ \\
\hline $\begin{array}{l}\text { Gross Beta }(\mathrm{pCi} / \mathrm{L}) \\
\text { Columbia River Water at Priest Rapid Dam } \\
\text { Columbia River Water at Richland Pumphouse } \\
200 \text { Area TEDF Effluent }\end{array}$ & $\begin{array}{l}12 \\
12 \\
48\end{array}$ & $\begin{array}{l}2.3 \\
2.2 \\
3.6\end{array}$ & $\begin{array}{c}1.1 \pm 0.36 \\
0.68 \pm 0.50 \\
1.45 \pm 0.14\end{array}$ \\
\hline $\begin{array}{l}\text { Total Uranium (pCi/L) } \\
\text { Columbia River Water at Priest Rapid Dam } \\
\text { Columbia River Water at Richland Pumphouse } \\
200 \text { Area TEDF Effluent } \\
\end{array}$ & $\begin{array}{l}12 \\
12 \\
48\end{array}$ & $\begin{array}{l}0.71 \\
0.68 \\
0.41\end{array}$ & $\begin{array}{l}0.48 \pm 0.056 \\
0.53 \pm 0.040 \\
0.24 \pm 0.025\end{array}$ \\
\hline $\begin{array}{l}\text { Radium-226 (pCi/L) } \\
\text { Columbia River Water at Upstream of } 300 \text { Area TEDF }^{(\mathrm{d})} \\
\text { Columbia River Water at Downstream of } 300 \text { Area TEDF }^{(\mathrm{d})} \\
200 \text { Area TEDF Effluent }\end{array}$ & $\begin{array}{c}1 \\
1 \\
12\end{array}$ & $\begin{array}{c}<0.05 \\
<0.01 \\
0.11\end{array}$ & $\begin{array}{c}<0.05 \\
<0.01 \\
0.06 \pm 0.016\end{array}$ \\
\hline $\begin{array}{l}\text { Radium-228 (pCi/L) } \\
\text { Columbia River Water at Upstream of } 300 \text { Area TEDF }^{(\mathrm{d})} \\
\text { Columbia River Water at Downstream of } 300 \text { Area TEDF }^{(\mathrm{d})} \\
200 \text { Area TEDF Effluent }\end{array}$ & $\begin{array}{c}1 \\
1 \\
12\end{array}$ & $\begin{array}{l}\text { ND } \\
\text { ND } \\
\text { ND }\end{array}$ & $\begin{array}{l}\text { ND } \\
\text { ND } \\
\text { ND }\end{array}$ \\
\hline \multicolumn{4}{|c|}{$\begin{array}{l}\text { a) Averages are reported as mean concentration } \pm 2 \text { standard error of the calculated mean. } \\
\text { b) Obtained from Hanford Site Environmental Report for Calendar Year } 1998 \text { (Dirkes et al. 1999). } \\
\text { c) Converted from } \mu \mathrm{g} / \mathrm{L} \text { to } \mathrm{pCi} / \mathrm{L} \text { by multiplying values reported by } 0.68 \mathrm{pCi} / \mu \mathrm{g} \text { ( } 40 \mathrm{CFR} 141, \mathrm{Vol} .56, \text { No. 138, } \\
\text { July } 18,1991, \text { page } 33068) \text {. } \\
\text { d) Obtained from the } 300 \text { Area Treated Effluent Disposal Facility, Department of Natural Resources Land Lease } \\
\text { Monitoring Report - September } 1998 \text { (WMH 1998). }\end{array}$} \\
\hline
\end{tabular}

Gross alpha and gross beta for CY 1998 (see Table 5a) appear to be slightly higher in effluent than in Columbia River water. However, for prior years there is no statistical difference between the mean values in effluent and river water (see Table 5c). The apparent higher effluent values for 1998 (see Table 5a) are an artifact of the higher detection limits used in 1998 for the effluent measurements. The mean of cadmium and lead was higher in effluent than in river water (see Table $5 \mathrm{~b}$ ). This is believed to be a result of higher detection limits for effluent (e.g., $0.01 \mu \mathrm{g} / \mathrm{L}$ for river water and $0.2 \mu \mathrm{g} / \mathrm{L}$ for effluent). The effluent detection limit for lead was higher for effluent than for river water $(0.21 \mu \mathrm{g} / \mathrm{L}$ versus $0.01 \mu \mathrm{g} / \mathrm{L})$, which contributed to the mean being higher for effluent than for the Columbia River water. 
Table 5b. Concentrations of Selected Chemical Constituent Concentrations Measured in Columbia River Water Compared to Concentrations Measured in the 200 Area TEDF Effluent

\begin{tabular}{|c|c|c|c|}
\hline \multirow[b]{2}{*}{ Parameter } & \multicolumn{3}{|c|}{ Calendar Year 1998} \\
\hline & $\begin{array}{c}\text { Number of } \\
\text { Samples }\end{array}$ & Maximum & Average $^{(a)}$ \\
\hline $\begin{array}{l}\text { Chloride (ppm) } \\
\text { Columbia River Water at Priest Rapid Dam } \\
\text { Columbia River Water at Richland Pumphouse } \\
200 \text { Area TEDF Effluent (all CY } 1998 \text { data) } \\
200 \text { Area TEDF Effluent (spikes removed) }\end{array}$ & $\begin{array}{c}15 \\
40 \\
48 \\
44^{(c)}\end{array}$ & $\begin{array}{l}1.09 \\
2.06 \\
66.48 \\
7.11^{(c)}\end{array}$ & $\begin{array}{c}0.925 \pm 0.052 \\
1.053 \pm 0.098 \\
6.389 \pm 3.041 \\
3.965 \pm 0.489^{(c)}\end{array}$ \\
\hline $\begin{array}{l}\text { Nitrate (as N) (ppm) } \\
\text { Columbia River Water at Priest Rapid Dam }{ }^{(b)} \\
\text { Columbia River Water at Richland Pumphouse } \\
200 \text { Area TEDF Effluent }\end{array}$ & $\begin{array}{l}15 \\
40 \\
48\end{array}$ & $\begin{array}{l}0.161 \\
0.494 \\
0.443\end{array}$ & $\begin{array}{l}0.096 \pm 0.026 \\
0.124 \pm 0.032 \\
0.177 \pm 0.024\end{array}$ \\
\hline $\begin{array}{l}\text { Sulfate (ppm) } \\
\text { Columbia River Water at Priest Rapid Dam } \\
\text { Columbia River Water at Richland Pumphouse } \\
200 \text { Area TEDF Effluent }\end{array}$ & $\begin{array}{l}15 \\
40 \\
48\end{array}$ & $\begin{array}{c}10.3 \\
13.2 \\
22.89 \\
\end{array}$ & $\begin{array}{c}8.67 \pm 0.63 \\
9.13 \pm 0.48 \\
15.84 \pm 1.24 \\
\end{array}$ \\
\hline $\begin{array}{l}\text { Total Arsenic (ppb) } \\
\text { Columbia River Water at Priest Rapid Dam } \\
\text { Columbia River Water at Richland Pumphouse } \\
200 \text { Area TEDF Effluent }\end{array}$ & $\begin{array}{r}17 \\
42 \\
.48\end{array}$ & $\begin{array}{c}0.96 \\
1.102 \\
5.91\end{array}$ & $\begin{array}{l}0.709 \pm 0.077 \\
0.721 \pm 0.044 \\
1.029 \pm 0.252\end{array}$ \\
\hline $\begin{array}{l}\text { Total Cadmium (ppb) } \\
\text { Columbia River Water at Priest Rapid Dam } \\
\text { Columbia River Water at Richland Pumphouse } \\
200 \text { Area TEDF Effluent }\end{array}$ & $\begin{array}{l}17 \\
42 \\
48\end{array}$ & $\begin{array}{c}0.0698 \\
0.0591 \\
0.61\end{array}$ & $\begin{array}{l}0.027 \pm 0.008 \\
0.027 \pm 0.004 \\
0.208 \pm 0.020\end{array}$ \\
\hline $\begin{array}{l}\text { Total Chromium (ppb) } \\
\text { Columbia River Water at Priest Rapid Dam } \\
\text { Columbia River Water at Richland Pumphouse } \\
200 \text { Area TEDF Effluent }\end{array}$ & $\begin{array}{l}17 \\
42 \\
48\end{array}$ & $\begin{array}{c}8.112 \\
1.016 \\
2.4\end{array}$ & $\begin{array}{l}0.838 \pm 0.926 \\
0.324 \pm 0.068 \\
0.976 \pm 0.113\end{array}$ \\
\hline $\begin{array}{l}\text { Total Lead (ppb) } \\
\text { Columbia River Water at Priest Rapid Dam } \\
\text { Columbia River Water at Richland Pumphouse } \\
200 \text { Area TEDF Effluent }\end{array}$ & $\begin{array}{l}17 \\
42 \\
48 \\
\end{array}$ & $\begin{array}{c}0.1672 \\
0.2355 \\
3.4 \\
\end{array}$ & $\begin{array}{l}0.100 \pm 0.018 \\
0.132 \pm 0.015 \\
0.542 \pm 0.170\end{array}$ \\
\hline $\begin{array}{l}\text { Total Iron (ppb) } \\
\text { Columbia River Water at Priest Rapids Dam } \\
\text { Columbia River Water at Richland Pumphouse } \\
200 \text { Area TEDF Effluent } \\
200 \text { Area TEDF Effluent (spikes removed) }\end{array}$ & $\begin{array}{c}10 \\
4 \\
48 \\
46^{(e)}\end{array}$ & $\begin{array}{c}24 \\
<10 \\
590 \\
313^{(e)}\end{array}$ & $\begin{array}{c}<10 \\
<10 \\
139 \pm 34 \\
122 \pm 25^{(\mathrm{e})}\end{array}$ \\
\hline $\begin{array}{l}\text { (a) Averages are reported as mean concentration } \pm 2 \text { star } \\
\text { (b) Obtained from Hanford Site Environmental Report } \\
\text { (c) Remove unrepresentative random spikes (chloride c } \\
\text { (d) Obtained from Hanford Site Environmental Report } \\
\text { data (Table A.4). } \\
\text { (e) Remove unrepresentative random spikes (iron conce } \\
\text { (f) } 42 \text { samples analyzed during CY } 1998 \text { were non-dete }\end{array}$ & $\begin{array}{l}\text { I of the calc } \\
\text { lar Year } 199 \\
\text { ion }>10 \mathrm{ppm} \\
\text { lar Year } 199 \\
\\
\end{array}$ & $\begin{array}{l}\text { mean. } \\
\text { kes et al }\end{array}$ & ased on USGS \\
\hline
\end{tabular}


Table 5c. Concentrations of Gross Alpha and Gross Beta Concentrations Measured in Columbia River Water Compared to Concentrations Measured in the 200 Area TEDF Effluent for Calendar Years 1995 to 1997

\begin{tabular}{|c|c|c|c|}
\hline Parameter & $\begin{array}{c}\text { Number of } \\
\text { Samples }\end{array}$ & Maximum & Average $^{(\mathrm{a})}$ \\
\hline \multicolumn{4}{|c|}{ Calendar Year 1995} \\
\hline $\begin{array}{l}\text { Gross Alpha (pCi/L) } \\
\text { Columbia River Water at Priest Rapid Dam }{ }^{(b)} \\
\text { Columbia River Water at Richland Pumphouse }{ }^{(b)} \\
200 \text { Area TEDF Effluent (grab and composite combined) }\end{array}$ & $\begin{array}{c}12 \\
4 \\
42\end{array}$ & $\begin{array}{c}0.800 \\
1.49 \\
2.9\end{array}$ & $\begin{array}{l}0.346 \pm 0.158 \\
1.05 \pm 0.30 \\
0.72 \pm 0.18\end{array}$ \\
\hline $\begin{array}{l}\text { Gross Beta }(\mathrm{pCi} / \mathrm{L}) \\
\text { Columbia River Water at Priest Rapid Dam }{ }^{(\mathrm{b})} \\
\text { Columbia River Water at Richland Pumphouse } \\
200 \text { Area TEDF Effluent }{ }^{\left({ }^{()}\right)} \text {(grab and composite.combined) }\end{array}$ & $\begin{array}{c}12 \\
4 \\
26\end{array}$ & $\begin{array}{l}3.36 \\
3.63 \\
2.10\end{array}$ & $\begin{array}{l}1.46 \pm 0.42 \\
1.95 \pm 1.42 \\
0.85 \pm 0.15\end{array}$ \\
\hline \multicolumn{4}{|c|}{ Calendar Year 1996} \\
\hline $\begin{array}{l}\text { Gross Alpha (pCi/L) } \\
\text { Columbia River Water at Priest Rapid } \text { Dam }^{(\mathrm{d})} \\
\text { Columbia River Water at Richland Pumphouse } \\
200 \text { Area TEDF Effluent (grab and composite combined) }\end{array}$ & $\begin{array}{l}13 \\
13 \\
88\end{array}$ & $\begin{array}{l}1.1 \\
1.7 \\
4.6\end{array}$ & $\begin{array}{l}0.38 \pm 0.21 \\
0.43 \pm 0.24 \\
0.86 \pm 0.14\end{array}$ \\
\hline $\begin{array}{l}\text { Gross Beta }(\mathrm{pCi} / \mathrm{L}) \\
\text { Columbia River Water at Priest Rapid Dam }{ }^{(\mathrm{d})} \\
\text { Columbia River Water at Richland Pumphouse } \\
200 \text { Area TEDF Effluent (grab and composite combined) }\end{array}$ & $\begin{array}{l}13 \\
13 \\
88\end{array}$ & $\begin{array}{l}3.0 \\
2.8 \\
3.4\end{array}$ & $\begin{array}{l}0.99 \pm 0.47 \\
1.1 \pm 0.49 \\
1.23 \pm 0.16\end{array}$ \\
\hline \multicolumn{4}{|c|}{ Calendar Year 1997} \\
\hline $\begin{array}{l}\text { Gross Alpha }(\mathrm{pCi} / \mathrm{L}) \\
\text { Columbia River Water at Priest Rapid Dam }{ }^{(e)} \\
\text { Columbia River Water at Richland Pumphouse } \\
200 \text { Area TEDF Effluent (grab only) }\end{array}$ & $\begin{array}{l}12 \\
12 \\
51\end{array}$ & $\begin{array}{c}0.82 \\
2.2 \\
2.8\end{array}$ & $\begin{array}{l}0.35 \pm 0.076 \\
0.58 \pm 0.16 \\
1.33 \pm 0.12\end{array}$ \\
\hline $\begin{array}{l}\text { Gross Beta (pCi/L) } \\
\text { Columbia River Water at Priest Rapid Dam } \\
\text { Columbia River Water at Richland Pumphouse } \\
200 \text { Area TEDF Effluent (grab only) }\end{array}$ & $\begin{array}{l}12 \\
12 \\
51\end{array}$ & $\begin{array}{l}3.2 \\
2.6 \\
5.3\end{array}$ & $\begin{array}{c}0.36 \pm 0.40 \\
1.2 \pm 0.21 \\
1.65 \pm 0.27\end{array}$ \\
\hline $\begin{array}{l}\text { (a) Averages are reported as mean concentration } \pm 2 \text { standard } \\
\text { (b) Obtained from Hanford Site } 1995 \text { Environmental Report (I } \\
\text { (c) Excluded excursions from PUREX release (i.e., prior to O } \\
\text { (d) Obtained from Hanford Site } 1996 \text { Environmental Report (I } \\
\text { (e) Obtained from Hanford Site } 1997 \text { Environmental Report (I }\end{array}$ & $\begin{array}{l}\text { or of the cal } \\
\text { rkes and } \mathrm{Ha} \\
\text { ber } 23,199 \\
\text { rkes and } \mathrm{Ha} \\
\text { rkes and } \mathrm{Ha}\end{array}$ & $\begin{array}{l}\text { ed mean. } \\
\text { 96). } \\
\text { a were rem } \\
\text { 97). } \\
\text { 98). }\end{array}$ & \\
\hline
\end{tabular}


Chloride and iron are higher in effluent than in Columbia River water for reasons previously discussed. The chloride concentration in effluent should approach the natural level in river water in the future. Iron spikes appear to be declining as well. It is also noteworthy that the maximum nitrate concentration observed for Columbia River water $(0.49 \mathrm{mg} / \mathrm{L})$ is close to the permit limit, suggesting that the permit limit should be raised.

In summary, the comparisons shown in Tables $5 \mathrm{a}$ and $\mathrm{b}$ indicate the current TEDF effluent is very similar to Columbia River water with a little added chloroform from the chlorinating process and some added chloride and iron (primarily particulate). 


\subsection{Justification for Permit Modification}

The low detection frequency for several permit constituents, the small number of actual permit limit exceedances (i.e., two iron exceedances over the 4-year period) and low exceedance probabilities for detected constituents indicate that a significant reduction in the number and/or type of routine measurements can be made with no risk to the environment. The approach or strategy relies on (1) the use of gross alpha and gross beta in lieu of isotope specific analyses, (2) elimination of analytes with a history of non-detects, and (3) reduction in frequency of sampling where appropriate. The rationale for modifying the permit requirements by eliminating selected analytes and changing sampling frequencies is as follows.

\subsection{Analyte Deletions}

\subsubsection{Radioisotopes}

Gross alpha (and gross beta) measurements can account for the total radionuclide content of a sample. These total activity measurements can thus be used in lieu of routine isotopic analyses until an appropriate threshold level is exceeded.

The monitoring results for total radium (radium-226 + radium-228) and radium-226 for the 4-year period indicate that both were consistently less than $5 \mathrm{pCi} / \mathrm{L}$ and $1 \mathrm{pCi} / \mathrm{L}$, respectively. (The detection limit for radium-226 is lower than for total radium.) The observed radium-226 in effluent is attributed to natural background sources that contribute to Columbia River water (see Table 5a) from upstream (e.g., uranium mining activities in the Spokane area). For the foregoing reasons, there is little to be gained by continuing routine total radium or radium-226 measurements. As long as gross alpha measurements are made, these isotope specific measurements can be eliminated from further routine monitoring.

The primary beta emitting radionuclides of concern are the moderately long-lived fission products, cesium-137 and strontium-90. The gross beta method can easily detect both of these radionuclides. The gross beta method is especially responsive for strontium- 90 because two beta emissions occur for each strontium-90 disintegration. Thus gross beta activity or concentration should be double the strontium-90 concentration.

The mean gross beta for Columbia River water (CY 1998) is about $1 \mathrm{pCi} / \mathrm{L}$ (see Table 5a). As with the gross alpha, the gross beta of the effluent stream is very low, similar to the low natural background of Columbia River water (see Table 5a). The overall mean of the effluent data over 4-years is $1.45 \mathrm{pCi} / \mathrm{L}$ (see Table 4). This overall mean value includes a few elevated gross beta values due to strontium-90 that occurred during the 4-year period. The consistently low values, other than these short-term excursions, can be seen in the time series plots (Appendix B). The low and consistent background concentration indicates that gross beta should be a good indicator of any beta emitting radionuclides added to the waste stream at concentrations of regulatory concern. Thus strontium-90 and cesium-137 (gamma energy analysis) can be eliminated from the routine monitoring list. 


\subsubsection{WTPH-G/Oil and Grease}

Petroleum products (hydrocarbons) are detected with the WTPH-G determination (light fraction or gasoline only). There were only 1 and 2 detected measurements out of a total of 37 analyses for WTPH-G and oil and grease, respectively, after June 1996 (see Table 3). The oil and grease method, which also involves a group determination of carbon compounds, was designed for biological lipids and mineral oils (APHA 1985, p. 496). These constituents are not likely to originate in Hanford facilities. Thus the oil and grease, as well as the WTPH-G analysis, can be removed from the analyte list.

\subsubsection{Semivolatile Organic Analytes (Semi-VOA)}

The semi-VOA group, phenol and bis(2-ethylhexyl)phthalate, can likewise be eliminated. Phenol was not detected in any of the samples analyzed during the study and bis(2-ethylhexyl)phthalate was detected only in 11 out of 200 composite sampling events in the 4-year period (see Table 3). Bis(2-ethylhexyl)phthalate is also ubiquitous (industrially) in plastics and is not associated with any past or current process or activity at Hanford.

\subsubsection{Volatile Organic Analytes (VOAs)}

Except for a few detections ( 6 out of a total 237 analyses or $<3 \%$ for methylene chloride, a common laboratory contaminant), the only VOAs consistently detected in the TEDF wastestream are the trihalomethanes. As previously noted, these compounds, especially chloroform, are associated with the chlorination of raw water. The concentrations in TEDF discharges are lower than the national median concentrations for drinking water supplies. Thus detailed VOA analyses can also be deleted from routine monitoring because the source of the only significant detections (chloroform) is.identified as a common disinfectant process (chlorination) used to sanitize potable water supplies. The resulting concentrations are at levels that poses no threat to groundwater.

\subsubsection{Cyanide}

Cyanide was detected in only 16 out of a total of 201 samples analyzed (see Table 3). The highest observed concentration was $27.2 \mathrm{ppb}$ on May 12, 1997. This maximum value is only about half of the early warning value in effluent $(50 \mathrm{ppb})$. It is also noteworthy that cyanide has not been detected since July 1997. Also, cyanide does not occur in any waste stream linked to TEDF. The only cyanide at Hanford is stored in single-shell tanks. However, the cyanide-containing waste from these tanks follows an entirely separate pathway, which is isolated from the TEDF waste streams. For the above reasons, cyanide can be eliminated from further routine monitoring. 


\subsection{Sampling Frequency and Type}

\subsubsection{Frequency}

Results of the statistical evaluation indicated that an adequate effluent monitoring program could be achieved with fewer sampling events for the following reasons:

- a significant decline in the number and magnitude of spike concentrations of constituents that previously approached or exceeded permit limits (e.g., iron)

- elimination of the 200 Areas power plants as waste stream contributors of chloride and iron

- a bi-weekly sampling frequency at the PFP wastewater treatment plant (self monitoring), the most significant remaining contributor source

- statistical evaluation results (e.g., variability and exceedance probabilities) for the routine sampling phase (Appendix $A$ and $B$ ) versus the more intensive sampling during the initial variability study (i.e., July 1995 through June 1996; Chou and Johnson 1996) are comparable. This suggests the less frequent sampling regime provided adequate temporal coverage.

The TEDF effluent monitoring program should now be viewed as an audit or periodic check on the efficacy of the contributor's effluent monitoring and control procedures. The audit function can therefore be accomplished with less frequent sample collections. Also; the original permit specified monthly rather than weekly grab sampling. Monthly is now deemed appropriate based on the 4-year period of observation and for the other reasons noted above.

\subsubsection{Sample Type}

Monthly results could be averaged over a quarter and the enforcement limits set on that basis rather than monthly averages of weekly grab samples or composite samples. The statistical evaluation also indicates there is little difference in observed (detected) analyte concentrations between a grab sample and a 24-hour composite sample. Thus a simple grab sample should provide the same temporal coverage as a composite run for only 24 hours where the objective is an overall monthly or quarterly average value. 


\subsection{Conclusions and Recommendations}

Based on the updated statistical evaluation of effluent monitoring data for June 1995 through June 1999 , it is concluded that the probability of exceeding permit limits under normal operating conditions is less than one in a million for all permitted constituents other than iron. The probability for the latter is four in one thousand. Except for iron (and two short-term releases of alpha and beta emitters), the current effluent is similar in composition to local drinking water (i.e., chlorinated Columbia River water). Results of the present study support the general findings and conclusions of the initial variability study (Chou and Johnson 1996).

As a result of the 4-year period of effluent monitoring and data evaluation, the TEDF effluent composition and variability of the effluent waste stream is now well defined. Accordingly, a revised or updated monitoring program that is specifically tailored to Hanford, and with fewer routine measurements, is deemed justified and appropriate.

Findings from the updated statistical evaluation of effluent monitoring data for TEDF lead to the following recommendations for a more efficient effluent monitoring program:

- Use gross alpha and gross beta in lieu of specific isotopic analyses (radium, cesium-137, and strontium-90) for routine monitoring. If the drinking water standards for gross alpha ( $15 \mathrm{pCi} / \mathrm{L})$ or . gross beta $(50 \mathrm{pCi} / \mathrm{L})$ are exceeded, then isotope specific measurements and an investigation of the exceedance can be conducted. 'Sufficient sample volume should be collected and archived to allow a later rerun if the gross count standards are exceeded.

- Eliminate unnecessary measurements. For example, VOAs, phenols and bis(2-ethylhexyl)phthalate, WTPH-G, oil and grease, and cyanide have been essentially undetected and are also unlikely based on process knowledge. Also, chloroform, the only VOA with significant or consistent detections, is a byproduct of a common water treatment process used in drinking water systems.

- Revise the nitrate limit to be consistent with groundwater protection standards (i.e., drinking water standard of $10 \mathrm{mg} / \mathrm{L}$ as nitrogen). The existing standard is too close to the background concentrations of nitrate in Columbia River water from agricultural activities.

- Use a roughing pre-filter or fine mesh screen to remove large particulates from the effluent samples collected for metal analyses. Rust particles are an inevitable consequence of the aging piping system. However, it is the colloidal and solute fractions that are of importance for groundwater protection purposes and not the flakes or rust particles that can be filtered out by the soil column. Thus it is not appropriate to include the large particles in the analysis of total iron (or other metals) by dissolving the large particulates for a "total" analysis. A more realistic effluent water sample is one that has been passed through a pre-filter or fine mesh screen prior to acidification and analysis. This modification in the sample collection procedure will more closely assess the potential impact on groundwater quality than the current procedure (digestion or dissolution of all particulates). 
- Eliminate the 24-hour composite and use only monthly grab samples to calculate a quarterly average for permit compliance purposes.

- Add low level tritium (once per year) as an effluent tracer to detect the presence of effluent in the TEDF groundwater monitoring network wells (additional details are discussed in the groundwater monitoring plan for TEDF).

The recommended modifications noted above are shown in Table 6a together with the current program and the original permit-specified conditions. Table $6 \mathrm{~b}$ summarizes the detection frequencies, variability and exceedance probabilities.

Implementation of the proposed changes (see Table 6a) will result in a more site-specific monitoring program and will improve the overall efficiency and cost effectiveness of TEDF monitoring activities. 
Table 6a. Current and Proposed Effluent Monitoring Plan for the 200 Area TEDF

\begin{tabular}{|c|c|c|c|}
\hline Parameter & $\begin{array}{c}\text { Permit } \\
\text { Requirement }\end{array}$ & $\begin{array}{l}\text { Current Sampling } \\
\text { Program }\end{array}$ & $\begin{array}{l}\text { Proposed Effluent } \\
\text { Monitoring Plan }\end{array}$ \\
\hline \multicolumn{4}{|c|}{ Volatile Organic Compounds } \\
\hline $\begin{array}{l}\text { Carbon tetrachloride } \\
\text { Methylene chloride } \\
\text { 1,1,1,-Trichloroethane } \\
\text { Total trihalomethanes } \\
\text { Bromoform } \\
\text { Bromodichloromethane } \\
\text { Chloroform } \\
\text { Dibromochloromethane }\end{array}$ & Grab 4/month & Grab 4/month & Eliminate \\
\hline \multicolumn{4}{|c|}{ Semivolatile Organic Compounds } \\
\hline $\begin{array}{l}\text { Bis(2-ethylhexyl)phthalate } \\
\text { Phenol }\end{array}$ & Composite 4/month & Composite $4 /$ month & Eliminate \\
\hline \multicolumn{4}{|c|}{ Metals } \\
\hline $\begin{array}{l}\text { Arsenic } \\
\text { Cadmium } \\
\text { Chromium } \\
\text { Lead } \\
\text { Mercury }\end{array}$ & $\begin{array}{c}\text { Unfiltered, } \\
\text { Composite 4/month }\end{array}$ & $\begin{array}{l}\text { Unfiltered, } \\
\text { Composite 4/month }\end{array}$ & $\begin{array}{l}\text { Filtered, } \\
\text { Grab 1/month }\end{array}$ \\
\hline $\begin{array}{l}\text { Iron } \\
\text { Manganese }\end{array}$ & $\begin{array}{c}\text { Unfiltered, } \\
\text { Composite } 1 / \text { month }\end{array}$ & $\begin{array}{c}\text { Unfiltered, } \\
\text { Composite 4/month }\end{array}$ & $\begin{array}{c}\text { Filtered, } \\
\text { Grab } 1 / \text { month }\end{array}$ \\
\hline \multicolumn{4}{|c|}{ Anions } \\
\hline $\begin{array}{l}\text { Chloride } \\
\text { Nitrate } \\
\text { Sulfate }\end{array}$ & Composite $1 /$ month & Composite $4 /$ month & Grab 1/month \\
\hline \multicolumn{4}{|c|}{ Other Analyses } \\
\hline Cyanide & Grab 4/month & Grab 4/month & Eliminate \\
\hline WTPH-G & Grab 1/month & Grab 1/month & Eliminate \\
\hline Oil and grease & Grab 1/month & Grab 1/month & Eliminate \\
\hline Total dissolved solids & Composite $1 /$ month & Composite 4/month & Grab 1/month \\
\hline \multicolumn{4}{|c|}{ Other Analyses } \\
\hline $\begin{array}{l}\text { Gross alpha } \\
\text { Gross beta } \\
\text { Total radium (Radium-226 and Radium-228) } \\
\text { Radium - } 226 \\
\text { Tritium (Low-level) }\end{array}$ & $\begin{array}{l}\text { Grab } 1 / \text { month } \\
\text { Grab } 1 / \text { month } \\
\text { Grab } 1 / \text { month } \\
\text { Grab } 1 / \text { month } \\
\text { Not required }\end{array}$ & $\begin{array}{l}\text { Grab 4/month } \\
\text { Grab 4/month } \\
\text { Grab 1/month } \\
\text { Grab 1/month } \\
\text {-- }\end{array}$ & $\begin{array}{l}\text { Grab } 1 / \text { month } \\
\text { Grab } 1 / \text { month } \\
\text { Eliminate } \\
\text { Eliminate } \\
\text { Grab } 1 / \text { year }\end{array}$ \\
\hline \multicolumn{4}{|c|}{ In-Line Monitoring } \\
\hline $\begin{array}{l}\text { Flow } \\
\text { Specific conductivity } \\
\text { pH }\end{array}$ & Continuous & Continuous & Continuous \\
\hline
\end{tabular}


Table 6b. Summary of TEDF Monitoring Results Based on Effluent Data Collected from July 1995 through June 1999

\begin{tabular}{|c|c|c|c|c|c|}
\hline \multirow[b]{2}{*}{ Parameter } & \multicolumn{3}{|c|}{ Detection Status ${ }^{(\mathrm{a})}$} & \multirow[b]{2}{*}{$\begin{array}{l}\text { Variability }^{(b)} \\
\text { CV (\%) } \\
\end{array}$} & \multirow[b]{2}{*}{$\begin{array}{l}\text { Exceedance } \\
\text { Probability }{ }^{(c)}\end{array}$} \\
\hline & $\begin{array}{c}\text { Total } \\
\text { Analyses } \\
\end{array}$ & $\begin{array}{c}\text { Detected } \\
\text { Analyses } \\
\text { (Grab) } \\
\end{array}$ & $\begin{array}{c}\text { Detected } \\
\text { Analyses } \\
\text { (Composite) } \\
\end{array}$ & & \\
\hline \multicolumn{6}{|c|}{ Volatile Organic Compounds } \\
\hline $\begin{array}{l}\text { Carbon tetrachloride } \\
\text { Methylene chloride } \\
\text { 1,1,1,-Trichloroethane } \\
\text { Total trihalomethanes } \\
\text { Bromoform } \\
\text { Bromodichloromethane } \\
\text { Chloroform } \\
\text { Dibromochloromethane } \\
\end{array}$ & $\begin{array}{l}237 \\
237 \\
237 \\
237 \\
237 \\
237 \\
237 \\
237 \\
\end{array}$ & $\begin{array}{c}0 \\
6 \\
0 \\
184 \\
0 \\
28 \\
193 \\
0 \\
\end{array}$ & NA & $73 \%$ & $\begin{array}{l}<1 \text { in } 1,000,000 \\
<1 \text { in } 1,000,000\end{array}$ \\
\hline \multicolumn{6}{|c|}{ Semivolatile Organic Compounds } \\
\hline $\begin{array}{l}\text { Bis(2-ethylhexyl)phthalate } \\
\text { Phenol }\end{array}$ & $\begin{array}{l}288 \\
288 \\
\end{array}$ & $\begin{array}{c}15 \\
0\end{array}$ & $\begin{array}{c}11 \\
0\end{array}$ & & \\
\hline \multicolumn{6}{|c|}{ Total Metals } \\
\hline $\begin{array}{l}\text { Arsenic } \\
\text { Cadmium } \\
\text { Chromium } \\
\text { Lead } \\
\text { Mercury } \\
\text { Iron }^{(d)} \\
\text { Manganese } \\
\end{array}$ & $\begin{array}{l}289 \\
289 \\
289 \\
289 \\
289 \\
291 \\
291 \\
\end{array}$ & $\begin{array}{c}4 \\
0 \\
9 \\
12 \\
21 \\
88 \\
51 \\
\end{array}$ & $\begin{array}{c}111 \\
19 \\
51 \\
99 \\
26 \\
203 \\
76 \\
\end{array}$ & $\begin{array}{l}85 \% \\
76 \% \\
\end{array}$ & $\begin{aligned} & 4 \text { in } 1,000 \\
&< 1 \text { in } 1,000,000 \\
&\end{aligned}$ \\
\hline \multicolumn{6}{|c|}{ Anions } \\
\hline $\begin{array}{l}\text { Chloride } \\
\text { Nitrate } \\
\text { Sulfate } \\
\end{array}$ & $\begin{array}{l}288 \\
288 \\
288 \\
\end{array}$ & $\begin{array}{l}88 \\
84 \\
88 \\
\end{array}$ & $\begin{array}{l}199 \\
196 \\
200 \\
\end{array}$ & $\begin{array}{l}152 \% \\
46 \% \\
36 \% \\
\end{array}$ & $\begin{array}{l}<1 \text { in } 1,000,000 \\
<1 \text { in } 1,000,000 \\
<1 \text { in } 1,000,000 \\
\end{array}$ \\
\hline \multicolumn{6}{|c|}{ Other Analyses } \\
\hline Cyanide & 201 & 16 & NA & & \\
\hline WTPH-G & 49 & 5 & $\mathrm{NA}$ & & \\
\hline Oil and grease & 112 & 23 & 27 & & \\
\hline Total dissolved solids & 164 & 9 & 155 & $33 \%$ & $<1$ in $1,000,000$ \\
\hline
\end{tabular}


Table 6b. (contd)

\begin{tabular}{|c|c|c|c|c|c|}
\hline \multirow[b]{2}{*}{ Parameter } & \multicolumn{3}{|c|}{ Detection Status $^{(a)}$} & \multirow[b]{2}{*}{$\begin{array}{c}\text { Variability }^{(b)} \\
\text { CV (\%) }\end{array}$} & \multirow[b]{2}{*}{$\begin{array}{l}\text { Exceedance } \\
\text { Probability }{ }^{(c)}\end{array}$} \\
\hline & $\begin{array}{c}\text { Total } \\
\text { Analyses }\end{array}$ & $\begin{array}{l}\text { Detected } \\
\text { Analyses } \\
\text { (Grab) } \\
\end{array}$ & $\begin{array}{c}\text { Detected } \\
\text { Analyses } \\
\text { (Composite) } \\
\end{array}$ & & \\
\hline \multicolumn{6}{|c|}{ Other Analyses } \\
\hline $\begin{array}{l}\text { Gross alpha } \\
\text { Gross beta } \\
\text { Total radium (Radium-226 and Radium-228) } \\
\text { Radium-226 }\end{array}$ & $\begin{array}{c}254 \\
254 \\
49 \\
49\end{array}$ & $\begin{array}{c}112 \\
112 \\
0 \\
19\end{array}$ & $\begin{array}{l}26 \\
36 \\
\text { NA } \\
\text { NA }\end{array}$ & $\begin{array}{l}83 \% \\
62 \%\end{array}$ & $\begin{array}{l}<1 \text { in } 1,000,000 \\
<1 \text { in } 1,000,000\end{array}$ \\
\hline \multicolumn{6}{|c|}{ In-Line Monitoring } \\
\hline $\begin{array}{l}\text { Flow } \\
\text { Specific conductivity } \\
\text { pH }\end{array}$ & NA & NA & NA & NA & $\mathrm{NA}$ \\
\hline \multicolumn{6}{|c|}{$\begin{array}{l}\text { (a) Obtained from Table } 2 \text { Detection Frequency Summary (based on analyses performed from July } 1995 \text { through June 1999). } \\
\text { (b) Variability is expressed as coefficient of variation (CV) and is obtained from Table } 4 \text {. } \\
\text { (c) Obtained from Table A-4 (Appendix A). } \\
\text { (d) Highest allowable average monthly concentration of } 258 \text { ppb was exceeded twice (April 7, } 1996 \text { and January 12, 1997) during the study } \\
\text { period (July } 1995 \text { through June 1999). }\end{array}$} \\
\hline
\end{tabular}




\subsection{References}

40 CFR 141, Code of Federal Regulations, Title 40, Vol. 56, No. 138, July 18, 1991, p. 33068. National Primary Drinking Water Regulations, Radionuclides.

APHA. 1985. Standard Methods for the Examination of Water and Wastewater, Sixteenth Edition. American Public Health Association, Washington, D.C.

Chou, C. J. and V. G. Johnson. 1996. Effluent Variability Study Results for the 200 Area Treated Effluent Disposal Facility. WHC-SD-LEF-EV-001, Rev. 0, Westinghouse Hanford Company, Richland, Washington.

Dirkes, R. L. and R. W. Hanf (eds.). 1996. Hanford Site 1995 Environmental Report. PNNL-11139, Pacific Northwest National Laboratory, Richland Washington.

Dirkes, R. L. and R. W. Hanf (eds.) 1997. Hanford Site 1996 Environmental Report. PNNL-11472, Pacific Norwest National Laboratory, Richland Washington.

Dirkes, R. L. and R. W. Hanf (eds.) 1998. Hanford Site 1997 Environmental Report. PNNL-11795, Pácific Northwest National Laboratory, Richland Washington.

Dirkes, R. L., R. W. Hanf, and T. M. Poston. 1999. Hanford Site Environmental Report for Calendar Year 1998. PNNL-12088, Pacific Northwest National Laboratory, Richland, Washington.

Ecology. 1995. State Waste Discharge Permit No. ST 4502. U.S. Department of Energy, Richland Operations Office, Washington Department of Ecology, Olympia, Washington, April 18, 1995.

EPA-600/4-79-020. 1983. "Section 160.1, Physical Properties: Residue, Filterable, Gravimetric, Dried at $180^{\circ} \mathrm{C}$." Methods for Chemical Analysis of Water and Wastes. U.S. Environmental Protection Agency, Washington, D.C.

EPA-600/4-79-020. 1983. "Section 335.3, Inorganic, Non-Metallics, Cyanide, Total, Colorimetric, Automated UV." Methods for Chemical Analysis of Water and Wastes. U.S. Environmental Protection Agency, Washington, D.C.

EPA-600/R-93-100. 1993. "Section 300.0, Determination of Inorganic Anions by Ion Chromatography Revision 2.1." Methods for the Determination of Inorganic Substances in Environmental Samples. U.S. Environmental Protection Agency, Washington, D.C.

EPA-600/R-94-111. 1994. "Section 200.8, Determination of Trace Elements in Water and Wastes by Inductively Coupled Plasma - Mass Spectrometry - Revision 5.4." Methods for the Determination of Metals in Environmental Samples - Supplement I. U.S. Environmental Protection Agency, Washington, D.C. . 
RCW 90.48, as amended, Title 90, Chapter 105. "Water Pollution Control Act." Revised Code of Washington. Olympia, Washington.

SW-846. 1986. Test Methods for Evaluating Solid Wastes: Physical/Chemical Methods, $3^{\text {rd }}$ ed. Office of Solid Waste and Emergency Response, U.S. Environmental Protection Agency, Washington, D.C.

WAC 173-200. "Water Quality Standards for Ground Waters of the State of Washington." Washington Administrative Code. Olympia, Washington.

WAC 173-216. "State Waste Discharge Program." Washington Administrative Code. Olympia, Washington.

WHC. 1995. 200 Area TEDF Effluent Sampling and Analysis Plan. WHC-SD-LEF-PLN-002, Rev. 1, Westinghouse Hanford Company, Richland, Washington.

WMH. 1998. Department of Natural Resources land Lease Monitoring Report-September 1998. WMH-98651383.31, Waste Management Federal Services Hanford, Inc., Richland, Washington. 
Appendix A

\section{Statistical Data Tables}




\section{Appendix A}

\section{Statistical Data Tables}

This appendix contains the results of statistical computations performed on the raw effluent monitoring data collected from July 1995 through June 1999. A description of statistical methods used and definitions of terms is available in the precursor to this report (Chou and Johnson 1996).

The statistical data tables contained herein are updated versions of tables presented in the initial variability study report (Chou and Johnson 1996) and are designed to be stand-alone tables. For example, footnotes are provided at either the bottom of the page or at the end of each table and provide additional clarification or references to other sources and explain how anomalous data were handled. The monthly average concentrations of permit required analyte measurements over the 4-year period are tabulated in Table A-2. It should be noted in calculating these averages that measurements below the practical quantification levels were not replaced by zero as required for the Discharge Monitoring Report.

The data are arranged by year, sample type (grab versus composite) and by season (Fall, Winter, Spring or Summer). This format is a continuation of the format used for the variability study report referenced above. The original intent was to identify variations that might be attributable to either sample type or season of the year. The individual years are shown separately. since changes in analytical methods and operations that occurred during the 4-year period of data collection could influence the observed variability.

It should also be noted that both grab and 24-hour composites were collected and a more intensive sampling frequency was performed only during the first year for the effluent variability study. Thereafter sampling no longer included the samples and analytes required solely for the variability study. After June 1995 only routine monitoring to demonstrate compliance with the discharge limits was required. Accordingly, only one sample type was collected, depending on the analyte group involved. For example, grab samples are no longer collected for metals and anions.

\section{A.1 References}

Chou, C. J. and V. G. Johnson. 1996. Effluent Variability Study Results for the 200 Area Treated Effluent Disposal Facility. WHC-SD-LEF-EV-001, Rev. 0, Westinghouse Hanford Company, Richland, Washington.

WAC 173-200. "Water Quality Standards for Ground Waters of the State of Washington." Washington Administrative Code. Olympia, Washington. 
Table A-1. Detection ${ }^{(\mathfrak{a})}$ Status of Constituents Analyzed for the TEDF Effluent Variability Study (July 1995 through June 1996)

\begin{tabular}{|c|c|c|c|c|c|c|c|c|}
\hline \multirow[b]{2}{*}{ Parameter } & \multicolumn{4}{|c|}{ Grab Samples } & \multicolumn{4}{|c|}{ Composite Samples } \\
\hline & Summer & Fall & Winter & Spring & Summer & Fall & Winter & Spring \\
\hline \multicolumn{9}{|c|}{ Volatile Organic Compound } \\
\hline Carbon tetrachloride & $0 / 32$ & $0 / 8$ & $0 / 29$ & $0 / 17$ & $\ldots$ & $\overline{---}$ & -- & $-\cdots$ \\
\hline Methylene chloride & $0 / 32$ & $0 / 8$ & $0 / 29$ & $0 / 17$ & $-\ldots$ & --- & --- & -- \\
\hline $1,1,1$, - Trichloroethane & $0 / 32$ & $0 / 8$ & $0 / 29$ & $0 / 17$ & $\cdots$ & $\cdots$ & -.- & $\cdots$ \\
\hline Total trihalomethanes: & $32 / 32$ & $8 / 8$ & $29 / 29$ & $17 / 17$ & --- & -- & --- & --- \\
\hline Bromoform & $0 / 32$ & $0 / 8$ & $0 / 29$ & $0 / 17$ & $\cdots$ & --- & --- & $-\cdots$ \\
\hline Bromodichloromethane & $17 / 32$ & $0 / 8$ & $0 / 29$ & $2 / 17$ & $\cdots$ & $-\cdots$ & -.. & -.- \\
\hline Chloroform & $32 / 32$ & $8 / 8$ & $29 / 29$ & $17 / 17$ & --- & --- & -- & $-\cdots$ \\
\hline Dibromochloromethane & $0 / 32$ & $0 / 8$ & $0 / 29$ & $0 / 17$ & -- & $-\cdots$ & --- & $\ldots$ \\
\hline \multicolumn{9}{|c|}{ Semivolatile Organic Compound } \\
\hline Bis(2-ethy'thexyl)pathalate & $5 / 32$ & $2 / 8$ & $4 / 30$ & $4 / 17$ & $0 / 12$ & $1 / 9$ & $2 / 12$ & $2 / 17$ \\
\hline Phenol & $0 / 32$ & $0 / 8$ & $0 / 30$ & $0 / 17$ & $0 / 12$ & $1 / 9$ & $0 / 12$ & $0 / 17$ \\
\hline \multicolumn{9}{|c|}{ Total.Metals } \\
\hline Arsenic & $3 / 32$ & $0 / 8$ & $0 / 30$ & $0 / 17$ & $4 / 13$ & $0 / 9$ & $0 / 12$ & $0 / 17$ \\
\hline Cadmium & $0 / 32$ & $0 / 8$ & $0 / 30$ & $0 / 17$ & $0 / 13$ & $0 / 9$ & $0 / 12$ & $1 / 17$ \\
\hline Chromium & $0 / 32$ & $0 / 8$ & $5 / 30$ & $3 / 17$ & $1 / 13$ & $0 / 9$ & $0 / 12$ & $1 / 17$ \\
\hline Lead & $7 / 32$ & $0 / 8$ & $1 / 30$ & $3 / 17$ & $3 / 13$ & $1 / 9$ & $0 / 12$ & $5 / 17$ \\
\hline Mercury & $7 / 32$ & $4 / 8$ & $10 / 30$ & $0 / 17$ & $0 / 13$ & $4 / 9$ & $4 / 12$ & $0 / 17$ \\
\hline Iron & $32 / 32$ & $8 / 8$ & $30 / 30$ & $17 / 17$ & $13 / 13$ & 9/9. & $12 / 12$ & $17 / 17$ \\
\hline Manganese & $20 / 32$ & $3 / 8$ & $17 / 30$ & $10 / 17$ & $3 / 13$ & $2 / 9$ & $9 / 12$ & $9 / 17$ \\
\hline \multicolumn{9}{|c|}{ Anions } \\
\hline Chloride & $32 / 32$ & $8 / 8$ & $30 / 30$ & $17 / 17$ & $11 / 12$ & $9 / 9$ & $12 / 12$ & $17 / 17$ \\
\hline Nitrate (as N) & $28 / 32$ & $8 / 8$ & $30 / 30$ & $17 / 17$ & $11 / 12$ & $9 / 9$ & $11 / 12$ & $17 / 17$ \\
\hline Sulfate & $32 / 32$ & $8 / 8$ & $30 / 30$ & $17 / 17$ & $12 / 12$ & $9 / 9$ & $12 / 12$ & $17 / 17$ \\
\hline \multicolumn{9}{|c|}{ Other Analyses } \\
\hline Cyanide & $2 / 13$ & $4 / 8$ & $1 / 13$ & $2 / 16$ & $-\cdots$ & $\cdots$ & -- & -- \\
\hline WTPH-G & $0 / 3$ & $0 / 2$ & $0 / 3$ & $4 / 4$ & $-\ldots$ & $-\ldots$ & $\ldots$ & $\ldots$ \\
\hline Oil and grease & $2 / 4$ & $0 / 2$ & $2 / 9$ & $17 / 17$ & $6 / 13$ & $1 / 1$ & $3 / 12$ & $17 / 17$ \\
\hline Total dissolved solids & $\cdots$ & $1 / 1$ & $3 / 3$ & $4 / 4$ & $3 / 3$ & $2 / 2$ & $3 / 3$ & $4 / 4$ \\
\hline Gross Alpha & $9 / 9$ & $7 / 8$ & $26 / 30$ & $9 / 17$ & $3 / 3$ & $7 / 8$ & $9 / 12$ & $7 / 16$ \\
\hline Gross Beta & $9 / 9$ & $8 / 8$ & $30 / 30$ & $14 / 17$ & $3 / 3$ & $8 / 8$ & $11 / 12$ & $14 / 16$ \\
\hline Total radium & $0 / 3$ & $0 / 2$ & $0 / 3$ & $0 / 4$ & --- & $\cdots$ & --- & -.. \\
\hline Radium-226 & $1 / 3$ & $0 / 2$ & $0 / 3$ & $0 / 4$ & $\ldots$ & $\ldots$ & $\ldots$ & - \\
\hline
\end{tabular}


Table A-1. Detection ${ }^{(a)}$ Status of Constituents Analyzed for the TEDF Effluent Variability Study (July 1996 through June 1997)

\begin{tabular}{|c|c|c|c|c|c|c|c|c|}
\hline \multirow[b]{2}{*}{ Parameter } & \multicolumn{4}{|c|}{ Grab Samples } & \multicolumn{4}{|c|}{ Composite Samples } \\
\hline & Summer & Fall & Winter & Spring & Summer & Fall & Winter & Spring \\
\hline \multicolumn{9}{|c|}{ Volatile Organic Compound } \\
\hline Carbon tetrachloride & $0 / 13$ & $0 / 9$ & $0 / 13$ & $0 / 17$ & --- & $\overline{---}$ & $\overline{-\cdots}$ & $-\ldots$ \\
\hline Methylene chloride & $0 / 13$ & $0 / 9$ & $0 / 13$ & $0 / 17$ & $\ldots$ & $-\cdots$ & --- & -- \\
\hline $1,1,1,-$ Trichloroethane & $0 / 13$ & $0 / 9$ & $0 / 13$ & $0 / 17$ & $\cdots$ & $\cdots$ & --. & $-\cdots$ \\
\hline Total trihalomethanes: & $13 / 13$ & $6 / 9$ & $2 / 13$ & $14 / 17$ & $\ldots$ & --. & --- & $-\cdots$ \\
\hline Bromoform & $0 / 13$ & $0 / 9$ & $0 / 13$ & $0 / 17$ & --- & --- & --- & -..- \\
\hline Bromodichloromethane & $0 / 13$ & $0 / 9$ & $0 / 13$ & $0 / 17$ & $\cdots$ & -- & --- & $-\cdots$ \\
\hline Chloroform & $13 / 13$ & $7 / 9$ & $2 / 13$ & $14 / 17$ & --- & $-\cdots$ & -- & --- \\
\hline Dibromochloromethane & $0 / 13$ & $0 / 9$ & $0 / 13$ & $0 / 17$ & -- & $\ldots$ & $\ldots$ & $\ldots$ \\
\hline \multicolumn{9}{|c|}{ Semivolatile Organic Compound } \\
\hline Bis(2-ethylhexyl)pathalate & $\ldots$ & $-\cdots$ & $\cdots$ & $\cdots$ & $\overline{1 / 13}$ & $1 / 9$ & $0 / 13$ & $1 / 17$ \\
\hline Phenol &.-- & -..- & ... & ... & $0 / 13$ & $0 / 9$ & $0 / 13$ & $0 / 17$ \\
\hline \multicolumn{9}{|c|}{ Total Metals } \\
\hline Arsenic & $\overline{m-n}$ & $\ldots$ & $\bar{m}$ & $\overline{-n}$ & $3 / 13$ & $1 / 9$ & $4 / 13$ & $9 / 17$ \\
\hline Cadmium & $\cdots$ & --- ' & $\ldots$ & --- & $0 / 13$ & $1 / 9$ & $2 / 13$ & $2 / 17$ \\
\hline Chromium & -.. & --- & $\cdots$ & $\cdot-.$. & $1 / 13$ & $0 / 9$ & $4 / 13$ & $6 / 17$ \\
\hline Lead & --- & $\ldots$ & --- & $\ldots$ & $0 / 13$ & $6 / 9$ & $7 / 13$ & $17 / 17$ \\
\hline Mercury & $\ldots$ & --- & $\ldots$ & -- & $0 / 13$ & $1 / 9$ & $2 / 13$ & $8 / 17$ \\
\hline & $\ldots$ & --- & $\ldots$ & --- & $13 / 13$ & $9 / 9$ & $15 / 15$ & $17 / 17$ \\
\hline Manganese & $-\cdots$ & $\ldots$ & -- & $\cdots$ & $4 / 13$ & $3 / 9$ & $5 / 15$ & $3 / 17$ \\
\hline \multicolumn{9}{|c|}{ Anions } \\
\hline Chloride & -.. & -.. & $\cdots$ & $\ldots$ & $13 / 13$ & $9 / 9$ & $13 / 13$ & $17 / 17$ \\
\hline Nitrate (as N) & --- & -.- & -.. & $\cdots$ & $12 / 13$ & $9 / 9$ & $13 / 13$ & $17 / 17$ \\
\hline Sulfate & $\ldots$ & $\ldots$ & --. & $\ldots$ & $13 / 13$ & $9 / 9$ & $13 / 13$ & $17 / 17$ \\
\hline \multicolumn{9}{|c|}{ Other Analyses } \\
\hline Cyanide & $2 / 13$ & $1 / 9$ & $2 / 13$ & $2 / 17$ & --- & $\ldots$ & $\ldots$ & $\ldots$ \\
\hline WTPH-G & $1 / 3$ & $0 / 2$ & $0 / 3$ & $0 / 4$ & --- & $\ldots$ & $-\cdots$ & --- \\
\hline Oil and grease & $1 / 3$ & $0 / 2$ & $0 / 3$ & $0 / 4$ & -.-- & $\ldots$ & $\ldots$ & $\ldots$ \\
\hline Total dissolved solids & $\ldots$ & $\cdots$ & $-\cdots$ & $\cdots$ & $6 / 6$ & $9 / 9$ & $13 / 13$ & $17 / 17$ \\
\hline Gross Alpha & $7 / 13$ & $3 / 9$ & $5 / 13$ & $8 / 17$ & $\cdots$ & $\cdots$ & --- & $\cdots$ \\
\hline Gross Beta & $6 / 13$ & $7 / 9$ & $5 / 13$ & $5 / 17$ & --- & -.- & -.. & $\cdots$ \\
\hline Total radium & $0 / 3$ & $0 / 2$ & $0 / 3$ & $0 / 4$ & ח... & -- & --- & --- \\
\hline Radium-226 & $0 / 3$ & $2 / 2$ & $1 / 3$ & $3 / 4$ & --- & $\ldots$ & $\ldots$ &.-- \\
\hline
\end{tabular}


Table A-1. Detection ${ }^{(a)}$ Status of Constituents Analyzed for the TEDF Effluent Variability Study (July 1997 through June 1998)

\begin{tabular}{|c|c|c|c|c|c|c|c|c|}
\hline \multirow[b]{2}{*}{ Parameter } & \multicolumn{4}{|c|}{ Grab Samples } & \multicolumn{4}{|c|}{ Composite Samples } \\
\hline & Summer & Fall & Winter & Spring & Summer & Fall & Winter & Spring \\
\hline \multicolumn{9}{|c|}{ Volatile Organic Compound } \\
\hline Carbon tetrachloride & $0 / 13$ & $0 / 8$ & $0 / 13$ & $0 / 16$ & $\ldots$ & $\overline{-\cdots}$ & $\ldots$ & -- \\
\hline Methylene chloride & $0 / 13$ & $0 / 8$ & $0 / 13$ & $1 / 16$ & $-\cdots$ & $-\cdots$ & --- & $\ldots$ \\
\hline $1,1,1,-$ Trichloroethane & $0 / 13$ & $0 / 8$ & $0 / 13$ & $0 / 16$ & -- & -.. & -.. & --- \\
\hline Total trihalomethanes: & $10 / 13$ & $3 / 8$ & $1 / 13$ & $10 / 16$ & -.. & $\cdots$ & -- & -- \\
\hline Bromoform & $0 / 13$ & $0 / 8$ & $0 / 13$ & $0 / 16$ & $\cdots$ & $\cdots$ & $-\cdots$ & --. \\
\hline Bromodichloromethane & $0 / 13$ & $0 / 8$ & $0 / 13$ & $0 / 16$ & --- & -..- & $\cdots$ & $-\cdots$ \\
\hline Chloroform & $10 / 13$ & $3 / 8$ & $1 / 13$ & $12 / 16$ & 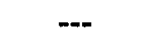 & --- & --- & -- \\
\hline Dibromochloromethane & $0 / 13$ & $0 / 8$ & $0 / 13$ & $0 / 16$ & $\cdots$ & $\cdots$ & $\cdots$ & -- \\
\hline \multicolumn{9}{|c|}{ Semivolatile Organic Compound } \\
\hline Bis(2-ethylhexyl)pathalate & $-\cdots$ & $\overline{---}$ & $\ldots$ & $\ldots$ & $1 / 13$ & $0 / 8$ & $1 / 13$ & $\overline{0 / 16}$ \\
\hline Phenol & $\cdots$ & $\cdots$ & $\ldots$ & -- & $0 / 13$ & $0 / 8$ & $0 / 13$ & $0 / 16$ \\
\hline \multicolumn{9}{|c|}{ Total.Metals } \\
\hline Arsenic & $\ldots$ & $\ldots$ & $\ldots$ & $\cdots$ & $11 / 13$ & $7 / 8$ & $11 / 13$ & $15 / 16$ \\
\hline Cadmium & $\cdots$ & -- & -.. & --- & $0 / 13$ & $1 / 8$ & $2 / 13$ & $2 / 16$ \\
\hline Chromium & $\cdots$ & -- & --- & --- & $1 / 13$ & $0 / 8$ & $4 / 13$ & $12 / 16$ \\
\hline Lead & $\cdots$ & -.. & $\cdots$ & $\cdots$ & $6 / 13$ & $1 / 8$ & $6 / 13$ & $9 / 16$ \\
\hline Mercury & -- & $\ldots$ & $\cdots$ & --- & $0 / 13$ & $0 / 8$ & $2 / 13$ & $1 / 16$ \\
\hline Iron & -- & -.. & $\ldots$ & -... & $13 / 13$ & $8 / 8$ & $13 / 13$ & $16 / 16$ \\
\hline Manganese & $\ldots$ & $\cdots$ & $\cdots$ & --- & $5 / 13$ & $1 / 8$ & $2 / 13$ & $4 / 16$ \\
\hline \multicolumn{9}{|c|}{ Anions } \\
\hline Chloride & -- & -- & $-\cdots$ & $\cdots$ & $13 / 13$ & $8 / 8$ & $13 / 13$ & $16 / 16$ \\
\hline Nitrate (as N) & --- & $\cdots$ & --- & --- & $13 / 13$ & $8 / 8$ & $13 / 13$ & $16 / 16$ \\
\hline Sulfate & $\ldots$ & $\cdots$ & -- & $-\cdots$ & $13 / 13$ & $8 / 8$ & $13 / 13$ & $16 / 16$ \\
\hline \multicolumn{9}{|c|}{ Other Analyses } \\
\hline Cyanide & $0 / 13$ & $0 / 8$ & $0 / 13$ & $0 / 16$ & -- & -- & $-\cdots$ & $\cdots$ \\
\hline WTPH-G & $0 / 3$ & $0 / 2$ & $0 / 3$ & $0 / 4$ & $\cdots$ & $\ldots$ & $\ldots$ & $-\cdots$ \\
\hline Oil and grease & $0 / 3$ & $0 / 2$ & $0 / 3$ & $0 / 4$ & $-\cdots$ & -- & $\cdots$ & $\cdots$ \\
\hline Total dissolved solids & $\ldots$ & $\cdots$ & -- & $\ldots$ & $13 / 13$ & $8 / 8$ & $13 / 13$ & $16 / 16$ \\
\hline Gross Alpha & $2 / 13$ & $1 / 8$ & $3 / 13$ & $7 / 16$ & $\ldots$ & $\overline{--}$ & --- & -- \\
\hline Gross Beta & $0 / 13$ & $4 / 8$ & $1 / 13$ & $2 / 16$ & --- & -.- & -.. & --- \\
\hline Total radium & $0 / 3$ & $0 / 2$ & $0 / 3$ & $0 / 4$ & $-\cdots$ & -- & --- & $\cdots$ \\
\hline Radium-226 & $3 / 3$ & $1 / 2$ & $1 / 3$ & $2 / 4$ & $\ldots$ &.- & -- & - \\
\hline
\end{tabular}


Table A-1. Detection ${ }^{(a)}$ Status of Constituents Analyzed for the TEDF Effluent Variability Study (July 1998 through June 1999)

\begin{tabular}{|c|c|c|c|c|c|c|c|c|}
\hline \multirow[b]{2}{*}{ Parameter } & \multicolumn{4}{|c|}{ Grab Samples } & \multicolumn{4}{|c|}{ Composite Samples } \\
\hline & Summer & Fall & Winter & Spring & Summer & Fall & Winter & Spring \\
\hline \multicolumn{9}{|c|}{ Volatile Organic Compound } \\
\hline Carbon tetrachloride & $0 / 12$ & $0 / 8$ & $0 / 12$ & $0 / 17$ & $\cdots$ & --- & -- & --- \\
\hline Methylene chloride. & $1 / 12$ & $0 / 8$ & $1 / 12$ & $3 / 17$ & -.. & --- & ..- & --- \\
\hline $1,1,1$, - Trichloroethane & $0 / 12$ & $0 / 8$ & $0 / 12$ & $0 / 17$ & $\cdots$ & -- & -- & --- \\
\hline Total trihalomethanes: & $11 / 12$ & $8 / 8$ & $10 / 12$ & $10 / 17$ & $-\cdots$ & --- & $-\cdots$ & $-\cdots$ \\
\hline Bromoform & $0 / 12$ & $0 / 8$ & $0 / 12$ & $0 / 17$ & $-\cdots$ & $\cdot--$ & $\ldots$ & $\cdots$ \\
\hline Bromodichloromethane & $2 / 12$ & $2 / 8$ & $5 / 12$ & $0 / 17$ & -.- & $\ldots$ & $\ldots$ & .-- \\
\hline Chloroform & $11 / 12$ & $-8 / 8$ & $11 / 12$ & $15 / 17$ & -- & --- & $-\cdots$ & $-\cdots$ \\
\hline Dibromochloromethane & $0 / 12$ & $0 / 8$ & $0 / 12$ & $0 / 17$ & -.. & --- & -..- & ... \\
\hline \multicolumn{9}{|c|}{ Semivolatile Organic Compound } \\
\hline Bis(2-ethylhexyl)pathalate & $\ldots$ & $\overline{---}$ & $\therefore$ & $0 / 1$ & $0 / 12$ & $0 / 8$ & $0 / 12$ & $1 / 16$ \\
\hline Phenol & $\ldots$ & --- & --- & $0 / 1$ & $0 / 12$ & $0 / 8$ & $.0 / 12$ & $0 / 16$ \\
\hline \multicolumn{9}{|c|}{ Total Metals } \\
\hline Arsenic & $-\cdots$ & -- & $\ldots$ & $1 / 1$ & $12 / 12$ & $8 / 8$ & $10 / 12$ & $16 / 16$ \\
\hline Cadmium & --- & $\ldots$ & -- & $0 / 1$ & $1 / 12$ & $3 / 8$ & $1 / 12$ & $3 / 16$ \\
\hline Chromium & $\ldots$ & 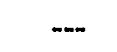 & $\ldots$ & $1 / 1$ & $9 / 12$ & $4 / 8$ & $2 / 12$ & $6 / 16$ \\
\hline Lead & $-\cdots$ & $\cdots$ & --- & $1 / 1$ & $10 / 12$ & $6 / 8$ & $9 / 12$ & $13 / 16$ \\
\hline Mercury &.-- & $\ldots$ & --. & $0 / 1$ & $0 / 12$ & $0 / 8$ & $2 / 12$ & $2 / 16$ \\
\hline Iron & --- & --- & --. & $1 / 1$ & $12 / 12$ & $8 / 8$ & $12 / 12$ & $16 / 16$ \\
\hline Manganese & -- & $-\cdots$ & $-\cdots$ & $1 / 1$ & $7 / 12$ & $2 / 8$ & $8 / 12$ & $9 / 16$ \\
\hline \multicolumn{9}{|c|}{ Anions } \\
\hline Chloride & -- & $\cdots$ & -- & $\overline{1 / 1}$ & $12 / 12$ & $8 / 8$ & $12 / 12$ & $16 / 16$ \\
\hline Nitrate (as N) & --- & $\ldots$ &.-- & $1 / 1$ & $12 / 12$ & $7 / 8$ & $12 / 12$ & $15 / 16$ \\
\hline Sulfate & --- & $\ldots$ & $-\ldots$ & $1 / 1$ & $12 / 12$ & $8 / 8$ & $12 / 12$ & $16 / 16$ \\
\hline \multicolumn{9}{|c|}{ Other Analyses } \\
\hline Cyanide & $0 / 12$ & $0 / 8$ & $0 / 12$ & $0 / 17$ & $\cdots$ & --- & $\cdots$ & $\ldots$ \\
\hline WTPH-G & $0 / 3$ & $0 / 2$ & $0 / 3$ & $0 / 5$ & $\cdots$ & $\ldots$ & $-\cdots$ & $\cdots$ \\
\hline Oil and grease & $0 / 3$ & $1 / 2$ & $0 / 3$ & $0 / 5$ & $\cdots$ & -- & $\ldots$ & $\cdots$ \\
\hline Total dissolved solids & $-\cdots$ & $\cdots$ & -- & $1 / 1$ & $12 / 12$ & $8 / 8$ & $12 / 12$ & $16 / 16$ \\
\hline Gross Alpha & $4 / 12$ & $2 / 8$ & $8 / 12$ & $11 / 17$ & $\cdots$ & $-\cdots$ & $\cdots$ & $\cdots$ \\
\hline Gross Beta & $4 / 12$ & $3 / 8$ & $6 / 12$ & $8 / 17$ & --- & ... & $\ldots$ & $\ldots$ \\
\hline Total radium & $0 / 3$ & $0 / 2$ & $0 / 3$ & $0 / 5$ & $\ldots$ & --- & -.- & -.. \\
\hline Radium-226 & $1 / 3$ & $1 / 2$ & $1 / 3$ & $2 / 5$ & --- & -.. & $\ldots$ & ... \\
\hline
\end{tabular}


Table A-2. Monthly Averages ${ }^{(\mathfrak{a})}$ for Detected Analytes

\begin{tabular}{|c|c|c|c|c|c|c|c|c|c|c|c|c|}
\hline Parameter & $\begin{array}{c}\text { July } \\
1995 \\
\end{array}$ & $\begin{array}{l}\text { Aug } \\
1995 \\
\end{array}$ & $\begin{array}{l}\text { Sept } \\
1995 \\
\end{array}$ & $\begin{array}{c}\text { Oct } \\
1995 \\
\end{array}$ & $\begin{array}{l}\text { Nov } \\
1995 \\
\end{array}$ & $\begin{array}{c}\text { Dec } \\
1995 \\
\end{array}$ & $\begin{array}{c}\text { Jan } \\
1996 \\
\end{array}$ & $\begin{array}{c}\text { Feb } \\
1996 \\
\end{array}$ & $\begin{array}{c}\text { Mar } \\
1996 \\
\end{array}$ & $\begin{array}{c}\text { Apr } \\
1996 \\
\end{array}$ & $\begin{array}{l}\text { May } \\
1996 \\
\end{array}$ & $\begin{array}{l}\text { June } \\
1996 \\
\end{array}$ \\
\hline $\begin{array}{l}\text { Chloroform } \\
\text { Grab } \\
\text { Composite } \\
\end{array}$ & $\begin{array}{c}14.00 \\
--- \\
\end{array}$ & $\begin{array}{c}9.64 \\
--- \\
\end{array}$ & $\begin{array}{c}8.64 \\
--- \\
\end{array}$ & $\begin{array}{c}8.25 \\
\ldots-\end{array}$ & $\begin{array}{c}6.75 \\
--- \\
\end{array}$ & $\begin{array}{r}5.60 \\
\ldots-\ldots \\
\end{array}$ & $\begin{array}{c}4.20 \\
-.- \\
\end{array}$ & $\begin{array}{c}4.44 \\
\ldots . .\end{array}$ & $\begin{array}{c}8.40 \\
\ldots .-\end{array}$ & $\begin{array}{c}7.50 \\
\ldots--\end{array}$ & $\begin{array}{c}12.50 \\
\ldots-\end{array}$ & $\begin{array}{c}8.75 \\
\ldots \ldots\end{array}$ \\
\hline $\begin{array}{l}\text { Total trihalomethanes } \\
\text { Grab } \\
\text { Composite }\end{array}$ & $\begin{array}{l}\text { NA } \\
--- \\
\end{array}$ & $\begin{array}{l}\text { NA } \\
--- \\
\end{array}$ & NA & $\begin{array}{c}\text { NA } \\
-.- \\
\end{array}$ & NA & $\begin{array}{l}\text { NA } \\
--- \\
\end{array}$ & NA & $\begin{array}{c}4.44 \\
--- \\
\end{array}$ & $\begin{array}{c}8.40 \\
---\end{array}$ & $\begin{array}{c}7.85 \\
--- \\
\end{array}$ & $\begin{array}{c}12.50 \\
\ldots .-\end{array}$ & $\begin{array}{c}8.75 \\
\ldots-\end{array}$ \\
\hline $\begin{array}{l}\text { Iron }^{\text {(c) }} \\
\text { Grab } \\
\text { Composite } \\
\end{array}$ & $\begin{array}{l}83.70 \\
80.75 \\
\end{array}$ & $\begin{array}{r}64.45 \\
42.00 \\
\end{array}$ & $\begin{array}{r}96.73 \\
25.60 \\
\end{array}$ & $\begin{array}{l}94.00 \\
95.80 \\
\end{array}$ & $\begin{array}{r}62.00 \\
33.75 \\
\end{array}$ & $\begin{array}{r}98.30 \\
106.75 \\
\end{array}$ & $\begin{array}{l}93.64 \\
79.20 \\
\end{array}$ & $\begin{array}{r}84.78 \\
117.67 \\
\end{array}$ & $\begin{array}{l}130.40 \\
156.40 \\
\end{array}$ & $\begin{array}{r}535.75 \\
891.25 \\
\end{array}$ & $\begin{array}{l}118.00 \\
106.25 \\
\end{array}$ & $\begin{array}{l}89.50 \\
83.50 \\
\end{array}$ \\
\hline $\begin{array}{l}\text { Manganese }^{(\mathrm{d}, \mathrm{d})} \\
\text { Grab } \\
\text { Composite }\end{array}$ & $\begin{array}{l}7.80 \\
6.25 \\
\end{array}$ & $\begin{array}{l}5.45 \\
4.25 \\
\end{array}$ & $\begin{array}{l}7.36 \\
4.00 \\
\end{array}$ & $\begin{array}{l}5.25 \\
6.00 \\
\end{array}$ & $\begin{array}{l}6.00 \\
4.00 \\
\end{array}$ & $\begin{array}{l}4.89 \\
6.75 \\
\end{array}$ & $\begin{array}{l}4.91 \\
6.40 \\
\end{array}$ & $\begin{array}{l}4.38 \\
4.67 \\
\end{array}$ & $\begin{array}{l}4.40 \\
4.60 \\
\end{array}$ & $\begin{array}{l}15.50 \\
14.00 \\
\end{array}$ & $\begin{array}{l}5.25 \\
6.00 \\
\end{array}$ & $\begin{array}{l}5.75 \\
5.25 \\
\end{array}$ \\
\hline $\begin{array}{l}\text { Arsenic }^{(b, c)} \\
\text { Grab } \\
\text { Composite } \\
\end{array}$ & $\begin{array}{c}0.22 \\
0 \\
\end{array}$ & $\begin{array}{l}0.17 \\
0.43 \\
\end{array}$ & $\begin{array}{l}0.25 \\
1.08 \\
\end{array}$ & $\begin{array}{l}0 \\
0 \\
\end{array}$ & $\begin{array}{l}0 \\
0 \\
\end{array}$ & $\begin{array}{l}0 \\
0 \\
\end{array}$ & $\begin{array}{l}0 \\
0 \\
\end{array}$ & $\begin{array}{l}0 \\
0 \\
\end{array}$ & $\begin{array}{l}0 \\
0 \\
\end{array}$ & $\begin{array}{l}0.75 \\
0.75\end{array}$ & $\begin{array}{l}1.50 \\
1.50\end{array}$ & $\begin{array}{l}1.50 \\
1.50\end{array}$ \\
\hline $\begin{array}{l}\text { Lead }^{(B, e)} \\
\text { Grab } \\
\text { Composite }\end{array}$ & $\begin{array}{l}0 \\
0 \\
\end{array}$ & $\begin{array}{l}1.45 \\
1.33 \\
\end{array}$ & $\begin{array}{l}0.35 \\
0.48 \\
\end{array}$ & $\begin{array}{c}0 \\
0.20 \\
\end{array}$ & $\begin{array}{l}0 \\
0 \\
\end{array}$ & $\begin{array}{c}0.16 \\
0 \\
\end{array}$ & $\begin{array}{l}0 \\
0 \\
\end{array}$ & $\begin{array}{l}0 \\
0\end{array}$ & $\begin{array}{c}0 \\
0.20\end{array}$ & $\begin{array}{l}0.50 \\
0.73\end{array}$ & $\begin{array}{l}0.58 \\
0.53\end{array}$ & $\begin{array}{l}0.55 \\
0.50\end{array}$ \\
\hline $\begin{array}{l}\text { Chloride }^{(\text {II) }} \\
\text { Grab } \\
\text { Composite } \\
\end{array}$ & $\begin{array}{l}2.47 \\
2.07 \\
\end{array}$ & $\begin{array}{l}2.50 \\
6.03 \\
\end{array}$ & $\begin{array}{c}10.46 \\
4.34 \\
\end{array}$ & $\begin{array}{r}9.15 \\
28.93 \\
\end{array}$ & $\begin{array}{l}2.35 \\
2.01 \\
\end{array}$ & $\begin{array}{l}2.36 \\
4.64 \\
\end{array}$ & $\begin{array}{c}1.93 \\
18.75 \\
\end{array}$ & $\begin{array}{c}18.98 \\
3.58 \\
\end{array}$ & $\begin{array}{c}22.48 \\
8.04 \\
\end{array}$ & $\begin{array}{l}2.49 \\
3.44 \\
\end{array}$ & $\begin{array}{l}3.07 \\
2.90\end{array}$ & $\begin{array}{l}3.45 \\
2.93\end{array}$ \\
\hline $\begin{array}{l}\text { Nitrate }^{(1)} \text { (as N) } \\
\text { Grab } \\
\text { Composite } \\
\end{array}$ & $\begin{array}{r}53.8 \\
115.0 \\
\end{array}$ & $\begin{array}{l}48.1 \\
57.0 \\
\end{array}$ & $\begin{array}{l}86.4 \\
92.0 \\
\end{array}$ & $\begin{array}{l}110.0 \\
98.0 \\
\end{array}$ & $\begin{array}{l}112.8 \\
121.8 \\
\end{array}$ & $\begin{array}{l}160.8 \\
180.8 \\
\end{array}$ & $\begin{array}{l}140.2 \\
153.4 \\
\end{array}$ & $\begin{array}{l}222.8 \\
173.3 \\
\end{array}$ & $\begin{array}{l}160.8 \\
182.8 \\
\end{array}$ & $\begin{array}{l}169.5 \\
176.3 \\
\end{array}$ & $\begin{array}{l}109.3 \\
105.5 \\
\end{array}$ & $\begin{array}{l}166.0 \\
168.5 \\
\end{array}$ \\
\hline $\begin{array}{l}\text { Sulfate }^{(6)}(\mathrm{ppm}) \\
\text { Grab } \\
\text { Composite }\end{array}$ & $\begin{array}{r}11.81 \\
9.24 \\
\end{array}$ & $\begin{array}{l}10.47 \\
10.91 \\
\end{array}$ & $\begin{array}{l}12.05 \\
12.80 \\
\end{array}$ & $\begin{array}{l}12.24 \\
11.64 \\
\end{array}$ & $\begin{array}{l}11.40 \\
11.30 \\
\end{array}$ & $\begin{array}{l}11.88 \\
10.24 \\
\end{array}$ & $\begin{array}{l}11.31 \\
12.04 \\
\end{array}$ & $\begin{array}{c}9.89 \\
10.20 \\
\end{array}$ & $\begin{array}{l}10.67 \\
11.32 \\
\end{array}$ & $\begin{array}{r}24.28 \\
22.55 \\
\end{array}$ & $\begin{array}{l}12.65 \\
12.20 \\
\end{array}$ & $\begin{array}{l}15.00 \\
20.95 \\
\end{array}$ \\
\hline $\begin{array}{l}\text { TDS }^{(\mathrm{k})}(\mathrm{ppm}) \\
\text { Grab } \\
\text { Composite }\end{array}$ & -... & $\begin{array}{c}--. \\
104\end{array}$ & 115 & 99 & $\begin{array}{l}129 \\
125 \\
\end{array}$ & $\begin{array}{l}84 \\
64 \\
\end{array}$ & $\begin{array}{l}56 \\
67 \\
\end{array}$ & $\begin{array}{l}46 \\
75 \\
\end{array}$ & $\begin{array}{l}121 \\
123 \\
\end{array}$ & $\begin{array}{l}141 \\
127 \\
\end{array}$ & $\begin{array}{l}70 \\
72 \\
\end{array}$ & $\begin{array}{l}71 \\
91 \\
\end{array}$ \\
\hline $\begin{array}{l}\text { Gross Alpha }{ }^{(1)}(\mathrm{pCi} / \mathrm{L}) \\
\text { Grab } \\
\text { Composite }\end{array}$ & $\begin{array}{c}0.34 \\
-\cdots \\
\end{array}$ & $\begin{array}{c}0.38 \\
--- \\
\end{array}$ & $\begin{array}{l}1.22 \\
0.87 \\
\end{array}$ & $\begin{array}{l}0.97 \\
1.12 \\
\end{array}$ & $\begin{array}{l}0.36 \\
0.29 \\
\end{array}$ & $\begin{array}{l}0.54 \\
0.56 \\
\end{array}$ & $\begin{array}{l}0.37 \\
0.37 \\
\end{array}$ & $\begin{array}{l}0.53 \\
1.18 \\
\end{array}$ & $\begin{array}{l}1.15 \\
0.88 \\
\end{array}$ & $\begin{array}{l}1.03 \\
0.96 \\
\end{array}$ & $\begin{array}{l}1.05 \\
1.30 \\
\end{array}$ & $\begin{array}{l}1.12 \\
0.75 \\
\end{array}$ \\
\hline $\begin{array}{l}\text { Gross Beta }{ }^{(m)}(\mathrm{pCi} / \mathrm{L}) \\
\text { Grab } \\
\text { Composite }\end{array}$ & $\cdots$ & $\cdots$ & $\begin{array}{l}42.83^{(n)} \\
30.63^{(n)} \\
\end{array}$ & $\begin{array}{l}25.33^{(n)} \\
25.88^{(n)} \\
\end{array}$ & $\begin{array}{l}0.79 \\
0.67 \\
\end{array}$ & $\begin{array}{l}0.98 \\
0.86 \\
\end{array}$ & $\begin{array}{l}0.50 \\
0.56 \\
\end{array}$ & $\begin{array}{l}1.37 \\
2.04 \\
\end{array}$ & $\begin{array}{l}1.84 \\
1.31 \\
\end{array}$ & $\begin{array}{l}1.44 \\
1.43 \\
\end{array}$ & $\begin{array}{l}1.32 \\
1.55\end{array}$ & $\begin{array}{l}0.92 \\
1.31\end{array}$ \\
\hline
\end{tabular}




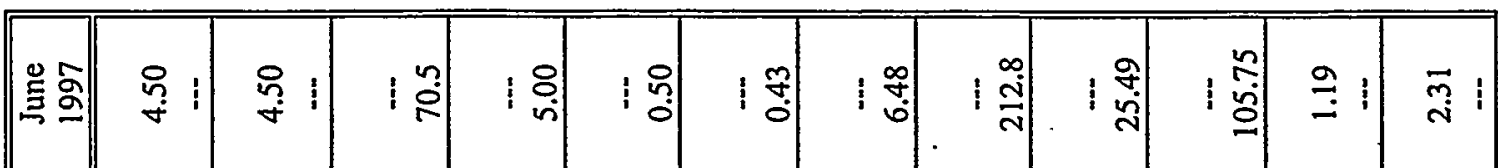

\begin{tabular}{|c|c|c|c|c|c|c|c|c|c|c|c|c|}
\hline 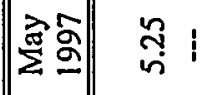 & సู่। & $\begin{array}{l}0 \\
0 \\
\infty \\
\vdots \\
\vdots\end{array}$ & $\mid \begin{array}{c}n \\
\infty\end{array}$ & i 웅 & $\stackrel{\infty}{\infty}$ & 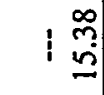 & i & & $\mid \begin{array}{l}\infty \\
\stackrel{0}{+}\end{array}$ & i & $\stackrel{\infty}{-}:$ & \\
\hline
\end{tabular}

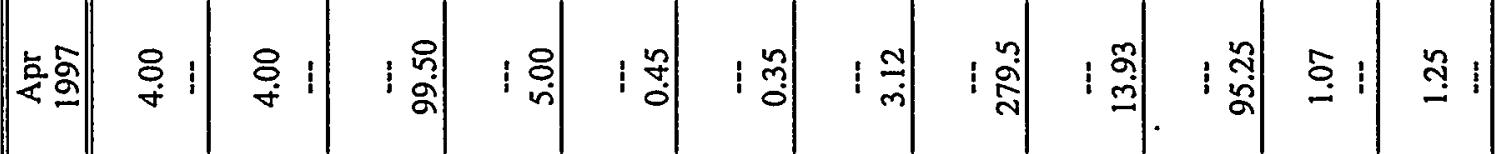

\begin{tabular}{|c|c|c|c|c|c|c|c|c|c|c|c|c|}
\hline |s & 莺! & $1 \stackrel{9}{\Xi}$ & 190 & 1 ?ี่ & is & 1 ? & i & & : & 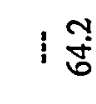 & F : & 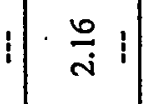 \\
\hline
\end{tabular}

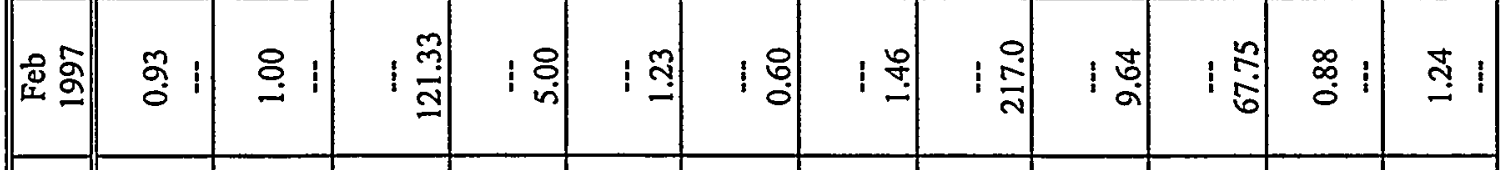

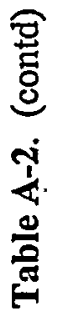

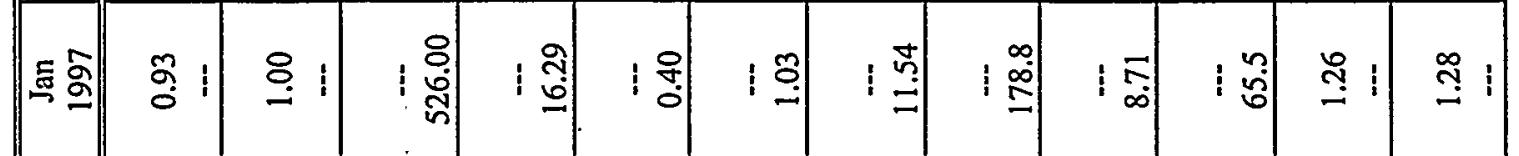

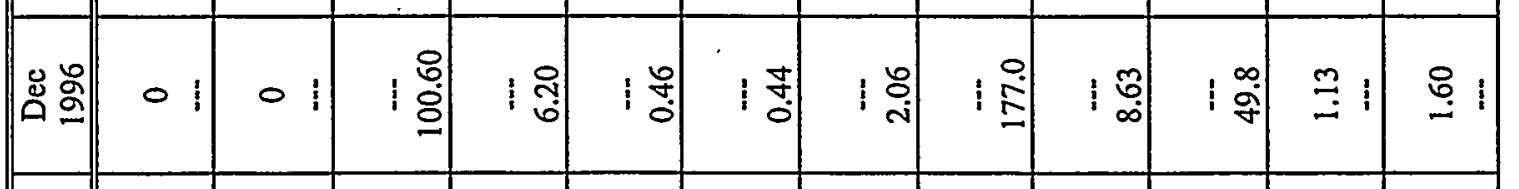

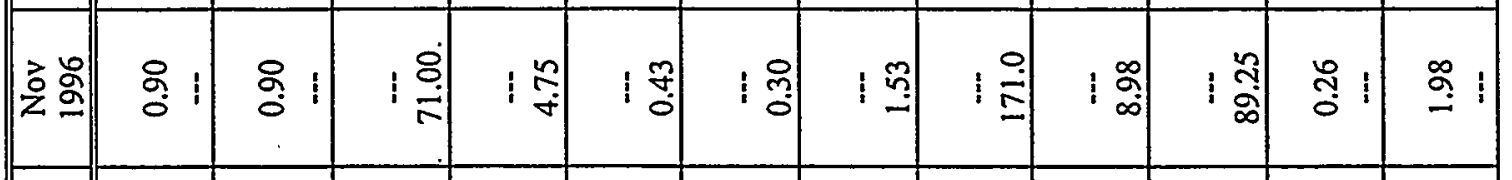

\begin{tabular}{|c|c|c|c|c|c|c|c|c|c|c|c|}
\hline 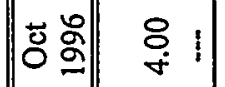 & $\underset{+}{8}$ & $\left|\begin{array}{c}0 \\
\vdots \\
\vdots\end{array}\right|$ & 융 & : & $\mid \begin{array}{c}\infty \\
0 \\
0\end{array}$ & $1 \tilde{n}$ & i & i & $\cdot:$ : & $\stackrel{\Xi}{-}$ & : \\
\hline
\end{tabular}

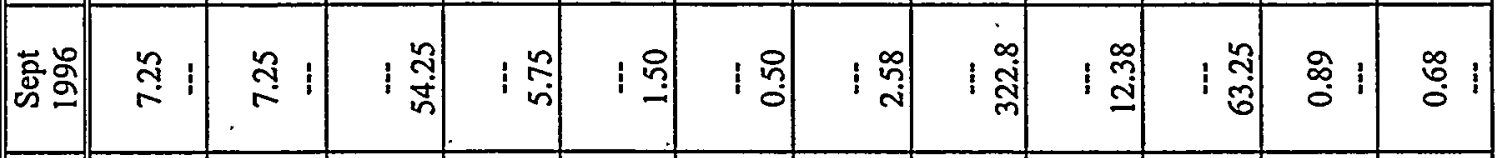

\begin{tabular}{|c|c|c|c|c|c|c|c|c|c|c|c|}
\hline 骂皇 & 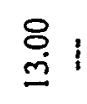 & 兽: & $\mid$\begin{tabular}{c}
$\stackrel{8}{*}$ \\
\multirow{\sigma}{*}{}
\end{tabular} & 18 & 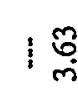 & 18 & I & ì & : & $\left.\right|_{\infty} ^{\infty}$ & $\frac{P}{0}$ \\
\hline
\end{tabular}

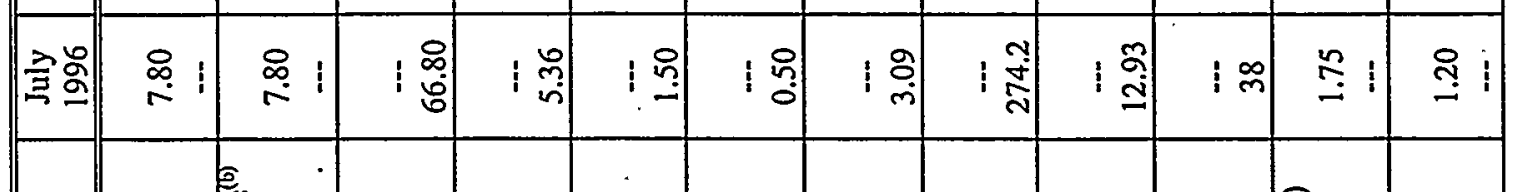

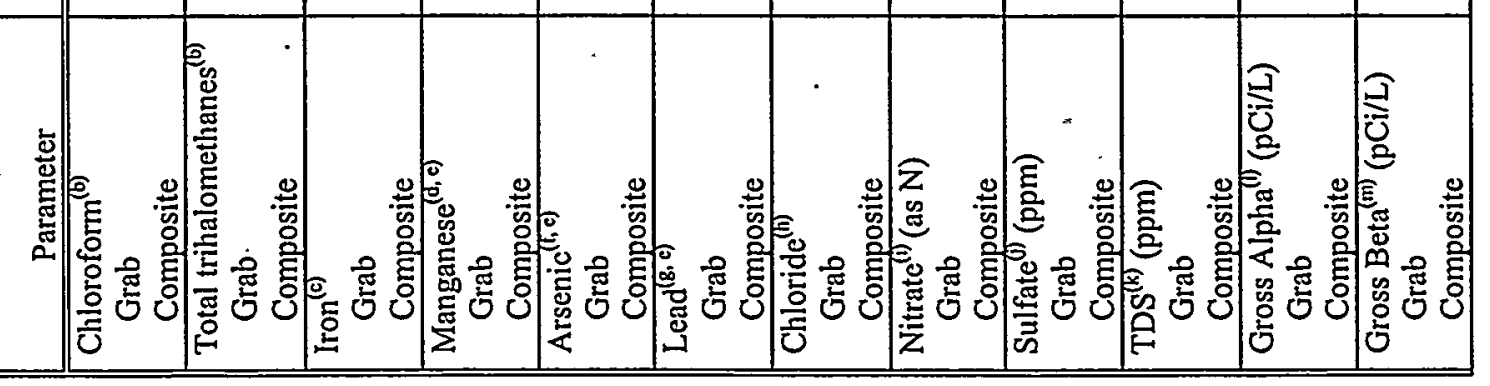

$$
\text { A. } 7
$$




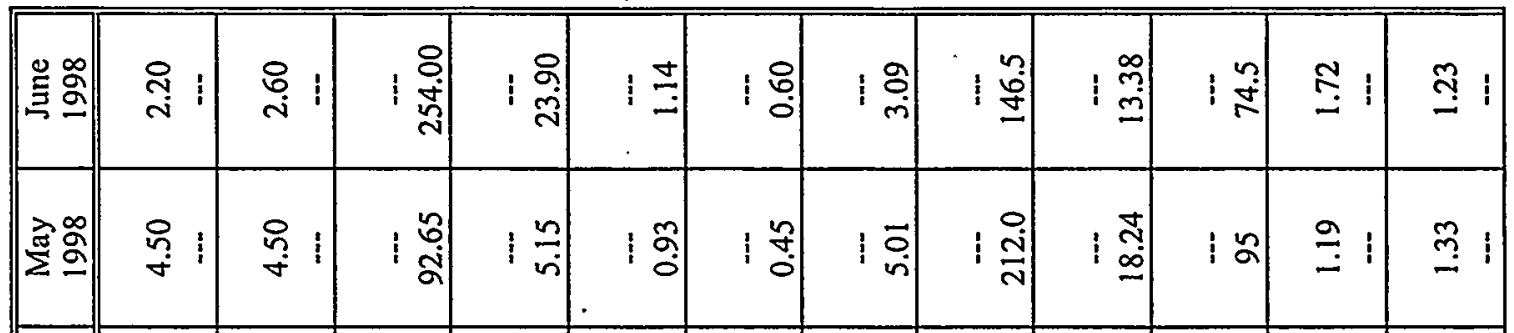

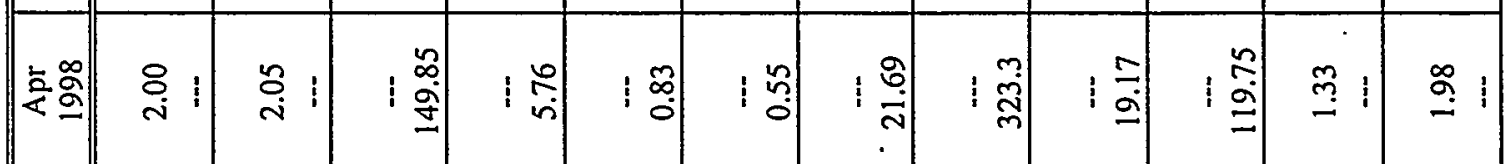

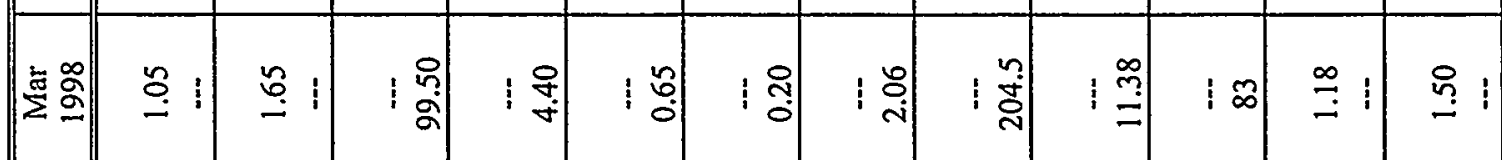

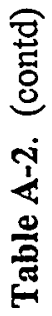

\begin{tabular}{|c|c|c|c|c|c|c|c|c|c|c|c|}
\hline 这 & \$: & $\stackrel{8}{\circ}$ & $\overbrace{\vec{\sigma}}^{\infty}$ & $1 \%$ & $\mid \begin{array}{c}\infty \\
0\end{array}$ & ণ্ণু & $\sqrt[n]{n}$ & $\mid \begin{array}{l}n \\
\infty \\
\infty\end{array}$ & $\stackrel{?}{\Xi}$ & $\underset{\infty}{\stackrel{\sim}{i}}$ & $\stackrel{1}{\infty}$ \\
\hline డ్ & 영 & 81 & $\frac{\pi}{\sigma}$ & $\stackrel{n}{\sim}$ & $\mid \begin{array}{c}0 \\
0 \\
0\end{array}$ & $\stackrel{\sim}{\sim}$ & $\frac{0}{I}$ & : & 1 ตุ. & $\stackrel{n}{m}$ & \\
\hline
\end{tabular}

\begin{tabular}{|c|c|c|c|c|c|c|c|c|c|c|}
\hline ๕ั ลำ & న్! & $\mid$ & 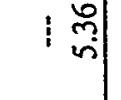 & $\left|\begin{array}{c}\infty \\
0 \\
0\end{array}\right|$ & ! & $\left|\begin{array}{c}8 \\
1 \\
n\end{array}\right|$ & 10 & $1 \stackrel{6}{=}$ & $1 \stackrel{0}{\infty}$ & $\stackrel{\infty}{=}: 1$ \\
\hline
\end{tabular}

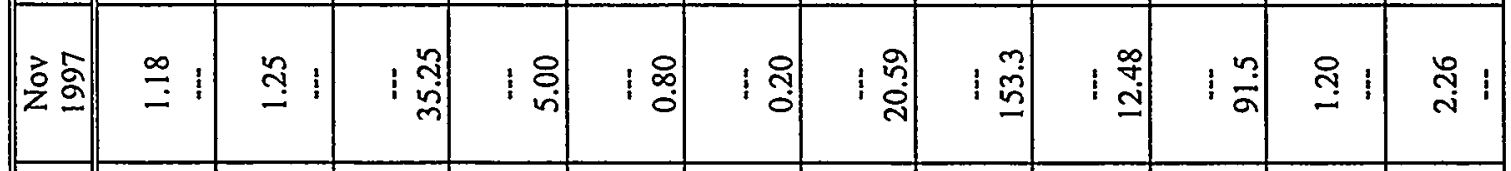

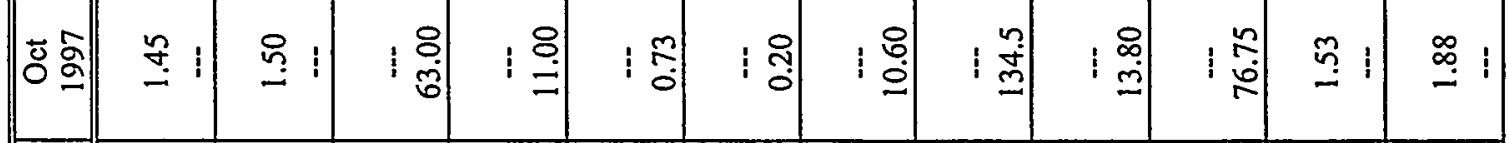

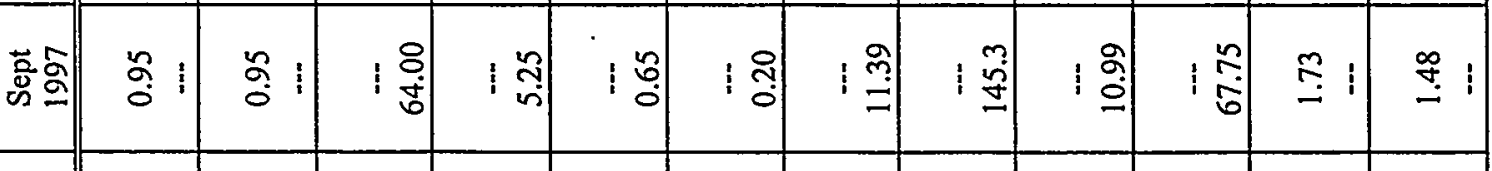

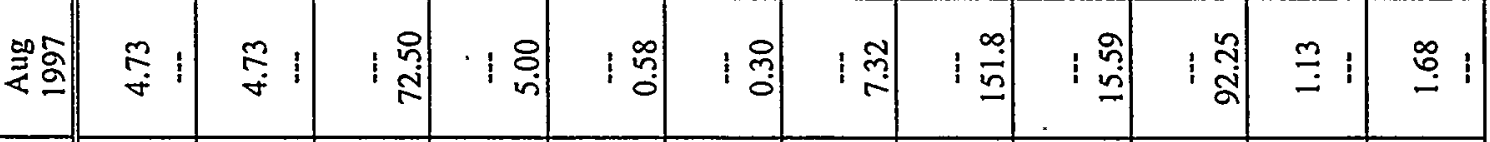

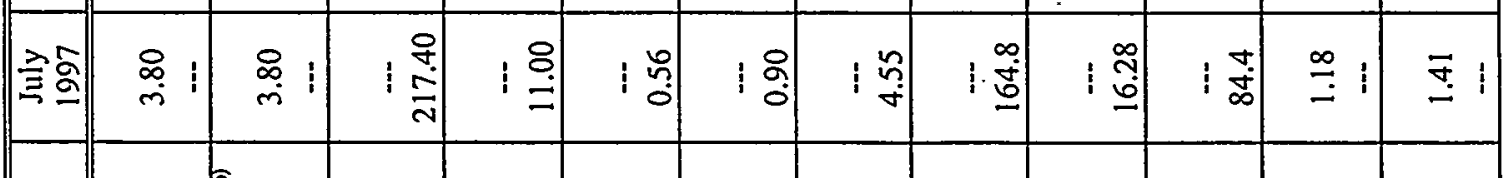

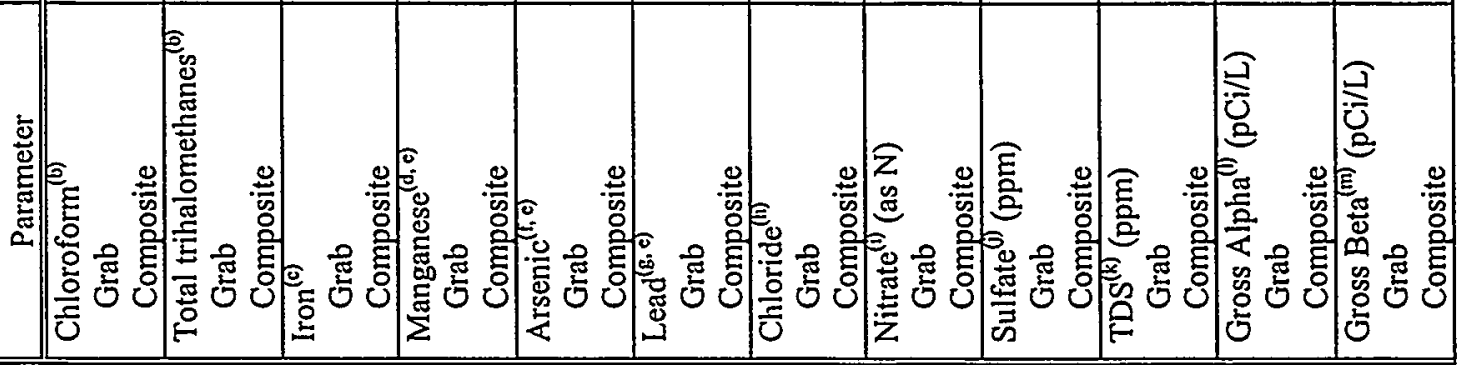

$$
\text { A.8 }
$$


Table A-2. (contd)

\begin{tabular}{|c|c|c|c|c|c|c|c|c|c|c|c|c|}
\hline Parameter & $\begin{array}{l}\text { July } \\
1998 \\
\end{array}$ & $\begin{array}{l}\text { Aug } \\
1998 \\
\end{array}$ & $\begin{array}{l}\text { Sept } \\
1998\end{array}$ & $\begin{array}{c}\text { Oct } \\
1998 \\
\end{array}$ & $\begin{array}{l}\text { Nov } \\
1998\end{array}$ & $\begin{array}{c}\text { Dec } \\
1998 \\
\end{array}$ & $\begin{array}{c}\text { Jan } \\
1999 \\
\end{array}$ & $\begin{array}{c}\text { Feb } \\
1999 \\
\end{array}$ & $\begin{array}{l}\text { Mar } \\
1999 \\
\end{array}$ & $\begin{array}{c}\text { Apr } \\
1999 \\
\end{array}$ & $\begin{array}{l}\text { May } \\
1999 \\
\end{array}$ & $\begin{array}{l}\text { June } \\
1999 \\
\end{array}$ \\
\hline $\begin{array}{l}\text { Chloroform }^{(b)} \\
\text { Grab } \\
\text { Composite } \\
\end{array}$ & $\begin{array}{c}6.75 \\
\ldots . \\
\end{array}$ & $\begin{array}{c}3.10 \\
\ldots \ldots \\
\end{array}$ & $\begin{array}{c}5.50 \\
-\ldots- \\
\end{array}$ & $\begin{array}{c}3.25 \\
\ldots \\
\end{array}$ & $\begin{array}{c}4.25 \\
\ldots \ldots \\
\end{array}$ & $\begin{array}{c}4.50 \\
--- \\
\end{array}$ & $\begin{array}{c}5.00 \\
-\cdots \\
\end{array}$ & $\begin{array}{c}2.35 \\
--- \\
\end{array}$ & $\begin{array}{c}2.75 \\
-. .- \\
\end{array}$ & $\begin{array}{c}1.48 \\
-\ldots \\
\end{array}$ & $\begin{array}{c}4.23 \\
--. \\
\end{array}$ & $\begin{array}{c}1.94 \\
-.- \\
\end{array}$ \\
\hline $\begin{array}{l}\text { Total trihalomethanes } \\
\text { Grab } \\
\text { Composite }\end{array}$ & $\begin{array}{c}7.05 \\
-.- \\
\end{array}$ & $\begin{array}{c}3.30 \\
\ldots- \\
\end{array}$ & $\begin{array}{c}5.50 \\
-\ldots \\
\end{array}$ & $\begin{array}{c}3.25 \\
\ldots\end{array}$ & $\begin{array}{c}4.55 \\
\ldots- \\
\end{array}$ & $\begin{array}{c}4.83 \\
\ldots-\end{array}$ & $\begin{array}{c}5.40 \\
\ldots . .\end{array}$ & $\begin{array}{c}2.56 \\
\ldots-\end{array}$ & $\begin{array}{c}2.75 \\
\ldots--\end{array}$ & $\begin{array}{c}1.60 \\
---\end{array}$ & $\begin{array}{c}4.35 \\
\ldots-\end{array}$ & $\begin{array}{c}2.32 \\
---\end{array}$ \\
\hline $\begin{array}{l}\text { Iron }{ }^{(\mathrm{c})} \\
\text { Grab } \\
\text { Composite }\end{array}$ & $\begin{array}{c}--- \\
224.68 \\
\end{array}$ & 105.33 & 150.50 & 90.60 & 194.25 & 178.50 & $\begin{array}{c}-- \\
127.98\end{array}$ & 205.0 & 200.75 & 128.33 & 152.83 & 161.15 \\
\hline $\begin{array}{l}\text { Manganese }^{(d, c)} \\
\text { Grab } \\
\text { Composite } \\
\end{array}$ & 11.58 & 6.88 & 6.50 & 4.40 & 7.09 & 6.54 & 4.64 & 9.26 & 5.06 & $\overline{4.40}$ & 9.27 & $\begin{array}{c}-.37 \\
11.37\end{array}$ \\
\hline $\begin{array}{l}\text { Arsenic }^{(1, a)} \\
\text { Grab } \\
\text { Composite } \\
\end{array}$ & 1.02 & 2.36 & $1 . \overline{8}$ & 1.00 & 0.82 & 0.53 & 0.50 & $0 . \overline{0 .}$ & 0.69 & 0.87 & $0 . \overline{-.}$ & $\overline{0.78}$ \\
\hline $\begin{array}{l}\text { Lead }^{(B, a)} \\
\text { Grab } \\
\text { Composite } \\
\end{array}$ & 1.35 & $\overline{0.40}$ & $\overline{0.83}$ & $\overline{0.36}$ & $\overline{0.74}$ & --- & 0.25 & $\begin{array}{c}-- \\
0.42\end{array}$ & $\overline{0.28}$ & $\overline{0.26}$ & $\overline{0.89}$ & $\overline{1.70}$ \\
\hline $\begin{array}{l}\text { Chloride }^{(h)} \\
\text { Grab } \\
\text { Composite }\end{array}$ & 4.39 & $\begin{array}{c}--. \\
3.31\end{array}$ & $7 . \overline{39}$ & $\begin{array}{r}-.60 \\
4.60\end{array}$ & 4.57 & 5.82 & 5.28 & $\begin{array}{c}-.39 \\
\end{array}$ & 3.70 & 5.54 & 10.02 & 3.79 \\
\hline $\begin{array}{l}\text { Nitrate }^{(i)} \text { (as N) } \\
\text { Grab } \\
\text { Composite }\end{array}$ & 153.8 & 125.5 & $1 \overline{147.3}$ & 127.5 & $\overline{122.5}$ & $\begin{array}{c}\cdots- \\
140.0\end{array}$ & $\begin{array}{r}-- \\
152.5 \\
\end{array}$ & $\begin{array}{c}--. \\
182.5 \\
\end{array}$ & 160.0 & $\overline{117.5}$ & 185 & $\begin{array}{r}--- \\
122.5 \\
\end{array}$ \\
\hline $\begin{array}{l}\text { Sulfate }^{(1)}(\mathrm{ppm}) \\
\text { Grab } \\
\text { Composite }\end{array}$ & $\begin{array}{c}--. \\
15.03\end{array}$ & $\begin{array}{c}-.- \\
15.28\end{array}$ & $\begin{array}{r}-. . \\
18.17\end{array}$ & $\begin{array}{c}-.- \\
18.03\end{array}$ & 20.48 & $\begin{array}{c}--- \\
19.97 \\
\end{array}$ & 23.55 & 22.56 & 22.58 & 24.79 & 23.40 & $\begin{array}{c}--. \\
15.08 \\
\end{array}$ \\
\hline $\begin{array}{l}\text { TDS }^{(k)}(\mathrm{ppm}) \\
\text { Grab } \\
\text { Composite }\end{array}$ & 84.25 & $\begin{array}{c}--- \\
90.75 \\
\end{array}$ & 82.25 & 88 & 93.5 & --- & $\begin{array}{c}-- \\
87.25\end{array}$ & $\ddot{86.5}$ & --- & 88.00 & 102.50 & 64.25 \\
\hline
\end{tabular}


Table A-2. (contd)

\begin{tabular}{|c|c|c|c|c|c|c|c|c|c|c|c|c|}
\hline Parameter & $\begin{array}{l}\text { July } \\
1998 \\
\end{array}$ & $\begin{array}{l}\text { Aug } \\
1998 \\
\end{array}$ & $\begin{array}{l}\text { Sept } \\
1998 \\
\end{array}$ & $\begin{array}{c}\text { Oct } \\
1998\end{array}$ & $\begin{array}{l}\text { Nov } \\
1998 \\
\end{array}$ & $\begin{array}{c}\text { Dec } \\
1998 \\
\end{array}$ & $\begin{array}{c}\text { Jan } \\
1999 \\
\end{array}$ & $\begin{array}{c}\text { Feb } \\
1999 \\
\end{array}$ & $\begin{array}{c}\text { Mar } \\
1999 \\
\end{array}$ & $\begin{array}{c}\mathrm{Apr} \\
1999 \\
\end{array}$ & $\begin{array}{l}\text { May } \\
1999 \\
\end{array}$ & $\begin{array}{l}\text { June } \\
1999 \\
\end{array}$ \\
\hline $\begin{array}{l}\text { Gross Alpha }{ }^{(1)}(\mathrm{pCi} / \mathrm{L}) \\
\text { Grab } \\
\text { Composite }\end{array}$ & $\begin{array}{c}2.53 \\
\ldots \ldots\end{array}$ & $\begin{array}{c}1.31 \\
---\end{array}$ & 1.49 & $\begin{array}{c}1.98 \\
\ldots-\end{array}$ & $\begin{array}{c}1.18 \\
---\end{array}$ & 1.14 & $24.4^{(0)}$ & $\begin{array}{c}7.55 \\
\ldots-\end{array}$ & $\begin{array}{c}3.40 \\
---\end{array}$ & $\begin{array}{c}7.45 \\
--.\end{array}$ & $\begin{array}{c}6.43 \\
--\end{array}$ & $\begin{array}{c}0.94 \\
\ldots\end{array}$ \\
\hline $\begin{array}{l}\text { Gross Beta }^{(\mathrm{m})}(\mathrm{pCi} / \mathrm{L}) \\
\text { Grab } \\
\text { Composite }\end{array}$ & $\begin{array}{c}1.35 \\
--- \\
\end{array}$ & $\begin{array}{c}1.18 \\
\ldots \\
\end{array}$ & $\begin{array}{c}1.73 \\
--. \\
\end{array}$ & $\begin{array}{c}1.98 \\
-\ldots- \\
\end{array}$ & $\begin{array}{c}1.28 \\
--- \\
\end{array}$ & $\begin{array}{c}1.24 \\
-.- \\
\end{array}$ & $\begin{array}{c}4.33 \\
-.- \\
\end{array}$ & $\begin{array}{c}2.35 \\
\ldots-. \\
\end{array}$ & $\begin{array}{c}1.25 \\
-- \\
\end{array}$ & $\begin{array}{c}1.28 \\
\ldots- \\
\end{array}$ & $\begin{array}{c}1.63 \\
\ldots- \\
\end{array}$ & $\begin{array}{c}1.03 \\
\ldots . \\
\end{array}$ \\
\hline
\end{tabular}

a) Units are in parts per billion (ppb) unless otherwise specified.

(b) Early warning value in effluent for total trihalomethanes is $66 \mathrm{ppb}$.

(c) Highest allowable average monthly effluent limit for total iron (unfiltered) is $258 \mathrm{ppb}$.

(d) Highest allowable average monthly effluent limit for total manganese (unfiltered) is $50 \mathrm{ppb}$.

(e) For the purpose of demonstrating permit compliance, non-detects were replaced with the applicable detection limit:

(f) Highest allowable average monthly effluent limit for total arsenic (unfiltered) is $15 \mathrm{ppb}$.

(g) Early warning value in effluent for total lead (unfiltered) is $10 \mathrm{ppb}$.

(h) Highest allowable average monthly effluent limit for chloride is $58 \mathrm{ppm}$.

(i) Highest allowable average monthly effluent limit for nitrate (as N) is $620 \mathrm{ppb}$.

(i) No permit limit is set for sulfate; the WAC 173-200 groundwater quality standard is $250 \mathrm{ppm}$

(k) Highest allowable average monthly effluent limit for total dissolved solids (TDS) is $250 \mathrm{ppm}$.

(l) No permit limit is set for gross alpha; the WAC 173-200 groundwater quality standard is $15 \mathrm{pCi} / \mathrm{L}$.

(m) No permit limit is set for gross beta; the WAC 173-200 groundwater quality standard for beta activity is $50 \mathrm{pCi} / \mathrm{L}$.

(n) Anomalous values were attributed to strontium-90 and cesium-137 from a one-time Plutonium-Uranium Extraction Plant (PUREX) release.

(o) Anomalous value was attributed to Plutonium Finishing Plant (PFP) release. 
Table A-3. Summary Statistics, Upper 95 Percent Confidence Limits (UCL) and Upper 95 Percent Tolerance Limits (UTL) for Detected Analytes

\begin{tabular}{|c|c|c|c|c|c|c|c|c|}
\hline \multirow[b]{3}{*}{ Summary Statistics ${ }^{(a)}$} & \multicolumn{8}{|c|}{$\overline{\text { Period (July } 1995 \text { through June 1996) }}$} \\
\hline & \multicolumn{2}{|c|}{$\begin{array}{c}\text { Summer } \\
\text { (July, Aug, Sept) }\end{array}$} & \multicolumn{2}{|c|}{$\begin{array}{c}\text { Fall } \\
\text { (Oct, Nov) }\end{array}$} & \multicolumn{2}{|c|}{$\begin{array}{c}\text { Winter } \\
\text { (Dec, Jan, Feb) }\end{array}$} & \multicolumn{2}{|c|}{$\begin{array}{c}\text { Spring } \\
\text { (Mar, Apr, May, June) } \\
\end{array}$} \\
\hline & Grab & Composite & Grab & Composite & Grab & Composite & Grab & Composite \\
\hline $\begin{array}{l}\text { Chloroform (ppb) } \\
\text { Number of samples } \\
\text { Mean } \\
\text { Standard Deviation } \\
\text { CV (\%) } \\
\text { 95\% UCL } \\
\text { 95\% UTL }\end{array}$ & $\begin{array}{c}32 \\
10.67 \\
3.33 \\
30.9 \\
11.8 \\
19.8\end{array}$ & NA & $\begin{array}{c}8 \\
7.52 \\
1.64 \\
21.8 \\
8.8 \\
14.6\end{array}$ & NA & $\begin{array}{c}29 \\
4.79 \\
1.73 \\
36.0 \\
5.4 \\
9.8\end{array}$ & NA & $\begin{array}{l}17 \\
9.32 \\
3.60 \\
38.7 \\
11.2 \\
22.0\end{array}$ & NA \\
\hline $\begin{array}{l}\text { Total trihalomethanes }(\mathrm{ppb}) \\
\text { Number of samples } \\
\text { Mean } \\
\text { Standard Deviation } \\
\text { CV (\%) } \\
95 \% \text { UCL } \\
95 \% \text { UTL }\end{array}$ & $\begin{array}{l}-\cdot- \\
--- \\
--- \\
-\cdots \\
--- \\
--\end{array}$ & $\mathrm{NA}$ & $\begin{array}{l}\cdots \\
\cdots \\
\cdots \\
\cdots \\
\cdots\end{array}$ & NA & $\begin{array}{c}10 \\
4.35 \\
1.7 \dot{3} \\
39.8 \\
5.7 \\
12.3\end{array}$ & NA & $\begin{array}{l}17 \\
9.40 \\
3.66 \\
38.9 \\
11.3 \\
22.3\end{array}$ & NA \\
\hline $\begin{array}{l}\text { Iron (ppb) } \\
\text { Number of samples } \\
\text { Mean } \\
\text { Standard Deviation } \\
\text { CV (\%) } \\
\text { 95\% UCL } \\
\text { 95\% UTL }\end{array}$ & $\begin{array}{c}32 \\
78.8 \\
62.7 \\
79.6 \\
102.7 \\
287.6\end{array}$ & $\begin{array}{c}13 \\
48.6 \\
36.6 \\
75.3 \\
76.3 \\
232.3 \\
\end{array}$ & $\begin{array}{c}8 \\
79.3 \\
52.4 \\
66.1 \\
142.3 \\
450.6\end{array}$ & $\begin{array}{c}9 \\
61.3 \\
53.4 \\
87.1 \\
127.6 \\
451.0\end{array}$ & $\begin{array}{c}30 \\
91.6 \\
41.8 \\
45.7 \\
106.6 \\
219.0\end{array}$ & $\begin{array}{c}12 \\
98.2 \\
39.6 \\
40.3 \\
124.2 \\
263.2\end{array}$ & $\begin{array}{c}16^{(b)} \\
113.1^{(b)} \\
37.8^{(b)} \\
33.4^{(b)} \\
132.7^{(b)} \\
243.9^{(b)}\end{array}$ & $\begin{array}{c}16^{(b)} \\
126.1^{(b)} \\
73.8^{(b)} \\
58.5^{(b)} \\
169.3^{(b)} \\
428.1^{(b)}\end{array}$ \\
\hline $\begin{array}{l}\text { Manganese (ppb) } \\
\text { Number of samples } \\
\text { Mean } \\
\text { Standard Deviation } \\
\text { CV (\%) } \\
95 \% \text { UCL } \\
\text { 95\% UTL }\end{array}$ & $\begin{array}{c}32 \\
6.68 \\
3.74 \\
56.0 \\
8.0 \\
18.3 \\
\end{array}$ & $\begin{array}{c}13 \\
4.70 \\
1.58 \\
33.7 \\
5.7 \\
10.7\end{array}$ & $\begin{array}{c}8 \\
5.62 \\
2.38 \\
42.3 \\
7.9 \\
18.9\end{array}$ & $\begin{array}{c}9 \\
5.04 \\
2.05 \\
40.6 \\
6.8 \\
15.3\end{array}$ & $\begin{array}{c}30 \\
4.68 \\
1.10 \\
23.5 \\
5.1 \\
7.6\end{array}$ & $\begin{array}{c}12 \\
6.05 \\
2.63 \\
43.4 \\
7.8 \\
17.9\end{array}$ & $\begin{array}{c}16^{(b)} \\
5.06^{(b)} \\
0.92^{(b)} \\
18.2^{(b)} \\
5.5^{(b)} \\
7.8^{(b)}\end{array}$ & $\begin{array}{c}16^{(b)} \\
5.37^{(b)} \\
1.36^{(b)} \\
25.3^{(b)} \\
6.0^{(b)} \\
9.8^{(b)}\end{array}$ \\
\hline $\begin{array}{l}\text { Chloride (ppm) } \\
\text { Number of samples } \\
\text { Mean } \\
\text { Standard Deviation } \\
\text { CV (\%) } \\
95 \% \text { UCL } \\
\text { 95\% UTL }\end{array}$ & $\begin{array}{c}32 \\
3.92 \\
3.77 \\
96.2 \\
5.4 \\
16.7 \\
\end{array}$ & $\begin{array}{c}11 \\
4.33 \\
3.15 \\
72.8 \\
7.1 \\
21.9\end{array}$ & $\begin{array}{c}8 \\
5.41 \\
6.22 \\
115.0 \\
17.0 \\
66.2 \\
\end{array}$ & $\begin{array}{c}9 \\
17.40 \\
49.51 \\
284.6 \\
161.8 \\
521.3 \\
\end{array}$ & $\begin{array}{c}30 \\
3.92 \\
4.68 \\
119.4 \\
5.9 \\
20.4 \\
\end{array}$ & $\begin{array}{c}12 \\
7.05 \\
11.39 \\
161.6 \\
22.4 \\
82.4 \\
\end{array}$ & $\begin{array}{c}17 \\
6.14 \\
6.92 \\
112.7 \\
10.9 \\
38.7\end{array}$ & $\begin{array}{c}17 \\
4.40 \\
2.76 \\
62.6 \\
6.0 \\
15.6\end{array}$ \\
\hline
\end{tabular}


Table A-3. (contd)

\begin{tabular}{|c|c|c|c|c|c|c|c|c|}
\hline \multirow[b]{3}{*}{ Summary Statistics ${ }^{(a)}$} & \multicolumn{8}{|c|}{ Period (July 1995 through June 1996) } \\
\hline & \multicolumn{2}{|c|}{$\begin{array}{c}\text { Summer } \\
\text { (July, Aug, Sept) }\end{array}$} & \multicolumn{2}{|c|}{$\begin{array}{c}\text { Fall } \\
\text { (Oct, Nov) }\end{array}$} & \multicolumn{2}{|c|}{$\begin{array}{c}\text { Winter } \\
\text { (Dec, Jan, Feb) }\end{array}$} & \multicolumn{2}{|c|}{$\begin{array}{c}\text { Spring } \\
\text { (Mar, Apr, May, June) }\end{array}$} \\
\hline & Grab & Composite & $\overrightarrow{\text { Grab }}$ & Composite & Grab & Composite & Grab & Composite \\
\hline $\begin{array}{l}\text { Nitrate (as N, ppb) } \\
\text { Number of samples } \\
\text { Mean } \\
\text { Standard Deviation } \\
\text { CV (\%) } \\
95 \% \text { UCL } \\
\text { 95\% UTL } \\
\end{array}$ & $\begin{array}{c}29 \\
72.08 \\
45.68 \\
63.4 \\
89.9 \\
219.4 \\
\end{array}$ & $\begin{array}{c}10 \\
101.18 \\
72.64 \\
71.8 \\
171.0 \\
537.0 \\
\end{array}$ & $\begin{array}{c}8 \\
113.85 \\
14.68 \\
12.9 \\
124.8 \\
170.0 \\
\end{array}$ & $\begin{array}{c}9 \\
109.06 \\
16.83 \\
15.4 \\
120.7 \\
171.6 \\
\end{array}$ & $\begin{array}{c}30 \\
169.68 \\
57.58 \\
33.9 \\
189.7 \\
334.4 \\
\end{array}$ & $\begin{array}{c}12 \\
168.91 \\
39.03 \\
23.1 \\
192.1 \\
307.2 \\
\end{array}$ & $\begin{array}{c}17 \\
152.13 \\
68.80 \\
45.2 \\
188.3 \\
405.1 \\
\end{array}$ & $\begin{array}{c}17 \\
160.15 \\
72.61 \\
45.3 \\
198.3 \\
427.3 \\
\end{array}$ \\
\hline $\begin{array}{l}\text { Sulfate (ppm) } \\
\text { Number of samples } \\
\text { Mean } \\
\text { Standard Deviation } \\
\text { CV (\%) } \\
\text { 95\% UCL } \\
\text { 95\% UTL } \\
\end{array}$ & $\begin{array}{c}32 \\
11.44 \\
2.35 \\
20.6 \\
12.2 \\
17.5 \\
\end{array}$ & $\begin{array}{r}11^{(\mathrm{c})} \\
11.92^{\mathrm{c}} \\
1.20^{\mathrm{c}} \\
10.0^{\mathrm{c}} \\
12.6^{\mathrm{c}} \\
15.6^{\mathrm{c}} \\
\end{array}$ & $\begin{array}{c}8 \\
12.24 \\
1.11 \\
9.1 \\
13.1 \\
16.3 \\
\end{array}$ & $\begin{array}{c}9 \\
11.49 \\
1.22 \\
10.6 \\
12.3 \\
15.7 \\
\end{array}$ & $\begin{array}{c}30 \\
11.07 \\
1.22 \\
11.0 \\
11.5 \\
14.1 \\
\end{array}$ & $\begin{array}{c}12 \\
11.00 \\
1.79 \\
16.3 \\
12.0 \\
16.9 \\
\end{array}$ & $\begin{array}{c}16^{(b)} \\
12.40^{(b)} \\
2.36^{(b)} \\
19.0^{(b)} \\
13.5^{(b)} \\
19.6^{(b)} \\
\end{array}$ & $\begin{array}{c}1^{(b)} \\
13.81^{(b)} \\
4.79^{(b)} \\
34.7^{(b)} \\
16.3^{(b)} \\
30.5^{(b)} \\
\end{array}$ \\
\hline $\begin{array}{l}\text { Total Dissolved Solids (ppm) } \\
\text { Number of samples } \\
\text { Mean } \\
\text { Standard Deviation } \\
\text { CV (\%) } \\
95 \% \text { UCL } \\
\text { 95\% UTL } \\
\end{array}$ & $\begin{array}{l}\cdots- \\
\cdots- \\
\cdots- \\
\cdots- \\
--\end{array}$ & $\begin{array}{c}3 \\
95.51 \\
33: 03 \\
34.6 \\
\mathrm{NC} \\
\mathrm{NC} \\
\end{array}$ & $\begin{array}{l}1 \\
\mathrm{NC} \\
\mathrm{NC} \\
\mathrm{NC} \\
\mathrm{NC} \\
\mathrm{NC} \\
\end{array}$ & $\begin{array}{c}2 \\
112.77 \\
18.72 \\
16.6 \\
\mathrm{NC} \\
\mathrm{NC} \\
\end{array}$ & $\begin{array}{c}3 \\
62.93 \\
19.79 \\
31.4 \\
\mathrm{NC} \\
\mathrm{NC} \\
\end{array}$ & $\begin{array}{c}3 \\
68.74 \\
5.62 \\
8.2 \\
\text { NC } \\
\text { NC } \\
\end{array}$ & $\begin{array}{c}4 \\
102.44 \\
38.28 \\
37.4 \\
\text { NC } \\
\text { NC }\end{array}$ & $\begin{array}{c}4 \\
104.28 \\
28.54 \\
27.4 \\
\text { NC } \\
\text { NC }\end{array}$ \\
\hline $\begin{array}{l}\text { Gross Alpha }(\mathrm{pCi} / \mathrm{L}) \\
\text { Number of samples } \\
\text { Mean } \\
\text { Standard Deviation } \\
\text { CV (\%) } \\
95 \% \text { UCL } \\
95 \% \text { UTL } \\
\end{array}$ & $\begin{array}{l}9 \\
1.06 \\
0.79 \\
74.5 \\
1.95 \\
6.4 \\
\end{array}$ & $\begin{array}{c}2 \\
0.99 \\
0.77 \\
77.8 \\
\text { NC } \\
\text { NC }\end{array}$ & $\begin{array}{c}8 \\
0.67 \\
0.52 \\
77.0 \\
1.36 \\
4.7 \\
\end{array}$ & $\begin{array}{c}9 \\
0.66 \\
0.60 \\
90.2 \\
1.43 \\
5.1 \\
\end{array}$ & $\begin{array}{c}30 \\
0.47 \\
0.24 \\
49.9 \\
0.56 \\
1.2 \\
\end{array}$ & $\begin{array}{c}12 \\
0.65 \\
0.56 \\
87.1 \\
1.14 \\
3.8 \\
\end{array}$ & $\begin{array}{c}17 \\
1.09 \\
0.38 \\
34.7 \\
1.28 \\
2.4 \\
\end{array}$ & $\begin{array}{l}16 \\
0.99 \\
0.46 \\
46.0 \\
1.25 \\
2.7 \\
\end{array}$ \\
\hline $\begin{array}{l}\text { Gross Beta }(\mathrm{pCi} / \mathrm{L}) \\
\text { Number of samples } \\
\text { Mean } \\
\text { Standard Deviation } \\
\text { CV (\%) } \\
95 \% \text { UCL } \\
95 \% \text { UTL } \\
\end{array}$ & $N C^{(d)}$ & $N C^{(d)}$ & $\begin{array}{c}6^{(\mathrm{d})} \\
0.82^{(\mathrm{d})} \\
0.24^{(\mathrm{d})} \\
28.8^{(\mathrm{d})} \\
1.09^{(\mathrm{d})} \\
2.2^{\text {(d) }} \\
\end{array}$ & $\begin{array}{c}6^{(\mathrm{d})} \\
0.66^{(\mathrm{d})} \\
0.35^{(\mathrm{d})} \\
53.5^{(\mathrm{d})} \\
1.21^{(\mathrm{d})} \\
3.7^{(\mathrm{d})} \\
\end{array}$ & $\begin{array}{c}30 \\
0.91 \\
0.53 \\
58.2 \\
1.11 \\
2.6 \\
\end{array}$ & $\begin{array}{l}12 \\
0.78 \\
0.46 \\
58.5 \\
1.12 \\
3.0 \\
\end{array}$ & $\begin{array}{c}17 \\
1.42 \\
0.62 \\
43.8 \\
1.74 \\
3.7 \\
\end{array}$ & $\begin{array}{c}16 \\
1.41 \\
0.60 \\
42.2 \\
1.73 \\
3.6 \\
\end{array}$ \\
\hline
\end{tabular}


Table A-3. (contd)

\begin{tabular}{|c|c|c|c|c|c|c|c|c|}
\hline \multirow[b]{3}{*}{ Summary Statistics ${ }^{(a)}$} & \multicolumn{8}{|c|}{ Period (July 1996 through June 1997). } \\
\hline & \multicolumn{2}{|c|}{$\begin{array}{c}\text { Summer } \\
\text { (July, Aug, Sept) }\end{array}$} & \multicolumn{2}{|c|}{$\begin{array}{c}\text { Fall } \\
\text { (Oct, Nov) }\end{array}$} & \multicolumn{2}{|c|}{$\begin{array}{c}\text { Winter } \\
\text { (Dec, Jan, Feb) }\end{array}$} & \multicolumn{2}{|c|}{$\begin{array}{c}\text { Spring } \\
\text { (Mar, Apr, May, June) }\end{array}$} \\
\hline & Grab & Composite & Grab & Composite & Grab & Composite & Grab & Composite \\
\hline $\begin{array}{l}\text { Chloroform (ppb) } \\
\text { Number of samples } \\
\text { Mean } \\
\text { Standard Deviation } \\
\text { CV (\%) } \\
\text { 95\% UCL } \\
\text { 95\% UTL }\end{array}$ & $\begin{array}{l}13 \\
9.30 \\
4.11 \\
44.2 \\
11.9 \\
26.2\end{array}$ & NA & $\begin{array}{c}9 \\
2.76 \\
2.94 \\
106.4 \\
7.0 \\
26.4\end{array}$ & $\mathrm{NA}$ & $\begin{array}{l}13 \\
\text { ND } \\
\text { NC } \\
\text { NC } \\
\text { NC } \\
\text { NC }\end{array}$ & NA & $\begin{array}{c}17 \\
3.86 \\
3.01 \\
78.1 \\
5.7 \\
16.9\end{array}$ & NA \\
\hline $\begin{array}{l}\text { Total trihalomethanes (ppb) } \\
\text { Number of samples } \\
\text { Mean } \\
\text { Standard Deviation } \\
\text { CV (\%) } \\
95 \% \text { UCL } \\
95 \% \text { UTL } \\
\end{array}$ & $\begin{array}{l}13 \\
9.30 \\
4.11 \\
44.2 \\
11.9 \\
26.2 \\
\end{array}$ & NA & $\begin{array}{c}9 \\
2.76 \\
2.94 \\
106.4 \\
7.0 \\
26.4 \\
\end{array}$ & NA & $\begin{array}{l}13 \\
\text { ND } \\
\text { NC } \\
\text { NC } \\
\text { NC } \\
\text { NC } \\
\end{array}$ & NA & $\begin{array}{c}17 \\
3.86 \\
3.01 \\
78.1 \\
5.7 \\
16.9 \\
\end{array}$ & NA: \\
\hline $\begin{array}{l}\text { Iron (ppb) } \\
\text { Number of samples } \\
\text { Mean } \\
\text { Standard Deviation } \\
\text { CV (\%) } \\
95 \% \text { UCL } \\
\text { 95\% UTL } \\
\end{array}$ & NA & $\begin{array}{c}13 \\
57.1 \\
21.7 \\
38.1 \\
70.4 \\
142.5 \\
\end{array}$ & NA & $\begin{array}{c}9 \\
78.1 \\
40.5 \\
51.8 \\
115.9 \\
304.4 \\
\end{array}$ & NA & $\begin{array}{c}14^{(\mathrm{e})} \\
104.0^{(\mathrm{e})} \\
107.5^{(\mathrm{e})} \\
103.3^{(\mathrm{e})} \\
190.7^{(\mathrm{e})} \\
671.2^{(\mathrm{e})} \\
\end{array}$ & NA & $\begin{array}{c}17 \\
5.79 \\
1.98 \\
34.2 \\
6.8 \\
12.5 \\
\end{array}$ \\
\hline $\begin{array}{l}\text { Manganese (ppb) } \\
\text { Number of samples } \\
\text { Mean } \\
\text { Standard Deviation } \\
\text { CV (\%) } \\
\text { 95\% UCL } \\
\text { 95\% UTL }\end{array}$ & NA & $\begin{array}{c}13 \\
5.37 \\
1.04 \\
19.3 \\
5.9 \\
8.8\end{array}$ & NA & $\begin{array}{c}9 \\
5.57 \\
1.13 \\
20.2 \\
6.4 \\
10.0\end{array}$ & NA & $\begin{array}{l}14^{(\mathrm{c})} \\
5.41^{(\mathrm{c})} \\
1.15^{(\mathrm{c})} \\
21.3^{(\mathrm{c})} \\
6.0^{(\mathrm{c})} \\
9.2^{(\mathrm{c})}\end{array}$ & $\mathrm{NA}$ & $\begin{array}{c}17 \\
5.79 \\
1.98 \\
34.2 \\
6.8 \\
12.5\end{array}$ \\
\hline $\begin{array}{l}\text { Chloride (ppm) } \\
\text { Number of samples } \\
\text { Mean } \\
\text { Standard Deviation } \\
\text { CV (\%) } \\
95 \% \text { UCL } \\
\text { 95\% UTL } \\
\end{array}$ & $\begin{array}{c}\text { NA } \\
-\end{array}$ & $\begin{array}{c}13 \\
6.22 \\
6.33 \\
101.8 \\
11.7 \\
41.4 \\
\end{array}$ & $\mathrm{NA}$ & $\begin{array}{c}9 \\
2.11 \\
0.70 \\
33.0 \\
2.7 \\
5.3 \\
\end{array}$ & NA & $\begin{array}{c}13 \\
3.91 \\
5.32 \\
136.0 \\
9.2 \\
35.6 \\
\end{array}$ & NA & $\begin{array}{l}17 \\
7.62 \\
7.40 \\
97.2 \\
12.5 \\
41.5 \\
\end{array}$ \\
\hline
\end{tabular}


Table A-3. (contd)

\begin{tabular}{|c|c|c|c|c|c|c|c|c|}
\hline \multirow[b]{3}{*}{ Summary Statistics ${ }^{(a)}$} & \multicolumn{8}{|c|}{ Period (July 1996 through June 1997) } \\
\hline & \multicolumn{2}{|c|}{$\begin{array}{c}\text { Summer } \\
\text { (July, Aug, Sept) }\end{array}$} & \multicolumn{2}{|c|}{$\begin{array}{c}\text { Fall } \\
\text { (Oct, Nov) }\end{array}$} & \multicolumn{2}{|c|}{$\begin{array}{c}\text { Winter } \\
(\mathrm{Dec}, \mathrm{Jan}, \mathrm{Feb})\end{array}$} & \multicolumn{2}{|c|}{$\begin{array}{c}\text { Spring } \\
\text { (Mar, Apr, May, June) }\end{array}$} \\
\hline & Grab & Composite & Grab & Composite & Grab & Composite & Grab & Composite \\
\hline $\begin{array}{l}\text { Nitrate (as N, ppb) } \\
\text { Number of samples } \\
\text { Mean } \\
\text { Standard Deviation } \\
\text { CV (\%) } \\
\text { 95\% UCL } \\
\text { 95\% UTL }\end{array}$ & NA & $\begin{array}{c}12 \\
302.48 \\
60.45 \\
20.0 \\
337.6 \\
509.7\end{array}$ & NA & $\begin{array}{c}9 \\
211.21 \\
70.73 \\
33.5 \\
267.8 \\
538.0\end{array}$ & $\mathrm{NA}$ & $\begin{array}{c}13 \\
189.95 \\
29.79 \\
15.7 \\
206.0 \\
284.5\end{array}$ & NA & $\begin{array}{c}17 \\
274.93 \\
92.99 \\
33.8 \\
321.2 \\
590.2\end{array}$ \\
\hline $\begin{array}{l}\text { Sulfate (ppm) } \\
\text { Number of samples } \\
\text { Mean } \\
\text { Standard Deviation } \\
\text { CV (\%) } \\
95 \% \text { UCL } \\
\text { 95\% UTL } \\
\end{array}$ & NA & $\begin{array}{c}13 \\
13.00 \\
1.25 \\
9.6 \\
13.6 \\
16.7 \\
\end{array}$ & NA & $\begin{array}{c}9 \\
10.56 \\
1.74 \\
16.5 \\
11.8 \\
17.1 \\
\end{array}$ & NA & $\begin{array}{c}9 \\
8.97 \\
0.82 \\
9.2 \\
9.4 \\
11.4 \\
\end{array}$ & NA & $\begin{array}{c}17 \\
18.39 \\
7.35 \\
39.9 \\
22.2 \\
44.4 \\
\end{array}$ \\
\hline $\begin{array}{l}\text { Total Dissolved Solids (ppm) } \\
\text { Number of samples } \\
\text { Mean } \\
\text { Standard Deviation } \\
\text { CV (\%) } \\
\text { 95\% UCL } \\
\text { 95\% UTL } \\
\end{array}$ & NA & $\begin{array}{c}6 \\
63.70 \\
18.74 \\
29.4 \\
85 \\
177.8 \\
\end{array}$ & NA & $\begin{array}{c}9 \\
77.22 \\
39.67 \\
51.4 \\
114.0 \\
297.8 \\
\end{array}$ & NA & $\begin{array}{c}13 \\
60.80 \\
28.42 \\
46.7 \\
79.2 \\
180.5 \\
\end{array}$ & NA & $\begin{array}{c}17 \\
90.33 \\
34.08 \\
37.7 \\
107.6 \\
209.3 \\
\end{array}$ \\
\hline $\begin{array}{l}\text { Gross Alpha }(\mathrm{pCi} / \mathrm{L}) \\
\text { Number of samples } \\
\text { Mean } \\
\text { Standard Deviation } \\
\text { CV (\%) } \\
95 \% \text { UCL } \\
95 \% \text { UTL }\end{array}$ & $\begin{array}{l}13 \\
1.12 \\
0.69 \\
61.3 \\
1.60 \\
4.3\end{array}$ & NA & $\begin{array}{c}7 \\
1.22 \\
1.60 \\
131.4 \\
5.5 \\
22.2 \\
\end{array}$ & $\mathrm{NA}$ & $\begin{array}{c}13 \\
1.10 \\
0.40 \\
36.5 \\
1.4 \\
2.7\end{array}$ & NA & $\begin{array}{c}17 \\
1.38 \\
0.46 \\
33.1 \\
1.6 \\
2.9\end{array}$ & NA \\
\hline $\begin{array}{l}\text { Gross Beta }(\mathrm{pCi} / \mathrm{L}) \\
\text { Number of samples } \\
\text { Mean } \\
\text { Standard Deviation } \\
\text { CV (\%) } \\
95 \% \text { UCL } \\
\text { 95\% UTL }\end{array}$ & $\begin{array}{c}12 \\
1.15 \\
0.99 \\
86.3 \\
2.01 \\
6.4\end{array}$ & NA & $\begin{array}{c}9 \\
1.93 \\
2.40 \\
123.9 \\
5.80 \\
22.6\end{array}$ & NA & $\begin{array}{c}13 \\
1.39 \\
0.62 \\
44.9 \\
1.79 \\
4.0\end{array}$ & NA & $\begin{array}{c}17 \\
1.81 \\
0.88 \\
48.7 \\
2.28 \\
5.2\end{array}$ & NA \\
\hline
\end{tabular}


Table A-3. (contd)

\begin{tabular}{|c|c|c|c|c|c|c|c|c|}
\hline \multirow[b]{3}{*}{ Summary Statistics ${ }^{(a)}$} & \multicolumn{8}{|c|}{ Period (July 1997 through June 1998) } \\
\hline & \multicolumn{2}{|c|}{$\begin{array}{c}\text { Summer } \\
\text { (July, Aug, Sept) }\end{array}$} & \multicolumn{2}{|c|}{$\begin{array}{c}\text { Fall } \\
\text { (Oct, Nov) }\end{array}$} & \multicolumn{2}{|c|}{$\begin{array}{c}\text { Winter } \\
\text { (Dec, Jan, Feb) }\end{array}$} & \multicolumn{2}{|c|}{$\begin{array}{c}\text { Spring } \\
\text { (Mar, Apr, May, June) }\end{array}$} \\
\hline & Grab & Composite & Grab & Composite & Grab & Composite & Grab & Composite \\
\hline $\begin{array}{l}\text { Chloroform (ppb) } \\
\text { Number of samples } \\
\text { Mean } \\
\text { Standard Deviation } \\
\text { CV (\%) } \\
\text {.95\% UCL } \\
\text { 95\% UTL } \\
\end{array}$ & $\begin{array}{c}13 \\
3.32 \\
3.43 \\
103.4 \\
6.3 \\
22.5 \\
\end{array}$ & NA & $\begin{array}{l}8 \\
\mathrm{ND} \\
\mathrm{NC} \\
\mathrm{NC} \\
\mathrm{NC} \\
\mathrm{NC}\end{array}$ & NA & $\begin{array}{l}13 \\
\text { ND } \\
\text { NC } \\
\text { NC } \\
\text { NC } \\
\text { NC }\end{array}$ & NA & $\begin{array}{c}16 \\
2.76 \\
3.93 \\
142.5 \\
5.9 \\
22.6\end{array}$ & NA \\
\hline $\begin{array}{l}\text { Total trihalomethanes (ppb) } \\
\text { Number of samples } \\
\text { Mean } \\
\text { Standard Deviation } \\
\text { CV (\%) } \\
95 \% \text { UCL } \\
\text { 95\% UTL } \\
\end{array}$ & $\begin{array}{c}13 \\
3.32 \\
3.43 \\
103.4 \\
6.3 \\
22.5 \\
\end{array}$ & NA & $\begin{array}{l}8 \\
N D \\
N C \\
N C \\
N C \\
\text { NC }\end{array}$ & NA & $\begin{array}{l}13 \\
N D \\
N C \\
N C \\
N C \\
N C\end{array}$ & NA & $\begin{array}{c}16 \\
2.71 \\
1.78 \\
65.8 \\
3.8 \\
10.3\end{array}$ & $\mathrm{NA}$ \\
\hline $\begin{array}{l}\text { Iron (ppb) } \\
\text { Number of samples } \\
\text { Mean } \\
\text { Standard Deviation } \\
\text { CV (\%) } \\
95 \% \text { UCL } \\
\text { 95\% UTL }\end{array}$ & NA & $\begin{array}{c}13 \\
127.5 \\
134.4 \\
105.4 \\
245.8 \\
934.0\end{array}$ & NA & $\begin{array}{c}8 \\
47.6 \\
30.8 \\
64.8 \\
84.2 \\
263.4\end{array}$ & NA & $\begin{array}{c}13 \\
73.0 \\
65.7 \\
90.0 \\
126.8 \\
424.1\end{array}$ & NA & $\begin{array}{c}16 \\
151.2 \\
174.5 \\
115.4 \\
279.9 \\
1,008.9\end{array}$ \\
\hline $\begin{array}{l}\text { Manganese (ppb) } \\
\text { Number of samples } \\
\text { Mean } \\
\text { Standard Deviation } \\
\text { CV (\%) } \\
95 \% \text { UCL } \\
\text { 95\% UTL }\end{array}$ & NA & $\begin{array}{c}13 \\
7.22 \\
3.79 \\
52.6 \\
9.8 \\
23.9\end{array}$ & NA & $\begin{array}{c}8 \\
7.56 \\
5.19 \\
68.7 \\
14.0 \\
45.2\end{array}$ & NA & $\begin{array}{l}13 \\
4.86 \\
0.81 \\
16.6 \\
5.3 \\
7.5\end{array}$ & NA & $\begin{array}{l}16 \\
8.45 \\
7.54 \\
89.3 \\
13.5 \\
43.5\end{array}$ \\
\hline $\begin{array}{l}\text { Chloride (ppm) } \\
\text { Number of samples } \\
\text { Mean } \\
\text { Standard Deviation } \\
\text { CV (\%) } \\
95 \% \text { UCL } \\
\text { 95\% UTL }\end{array}$ & NA & $\begin{array}{c}13 \\
7.30 \\
6.37 \\
87.4 \\
12.4 \\
41.0\end{array}$ & $\mathrm{NA}$ & $\begin{array}{c}8 \\
17.31 \\
18.78 \\
108.5 \\
50.4 \\
195.3\end{array}$ & $\mathrm{NA}$ & $\begin{array}{c}13 \\
5.57 \\
5.63 \\
101.0 \\
10.4 \\
36.8\end{array}$ & NA & $\begin{array}{c}16 \\
6.75 \\
9.43 \\
139.6 \\
14.2 \\
54.2\end{array}$ \\
\hline
\end{tabular}


Table A-3. (contd)

\begin{tabular}{|c|c|c|c|c|c|c|c|c|}
\hline \multirow[b]{3}{*}{ Summary Statistics ${ }^{(\mathrm{a})}$} & \multicolumn{8}{|c|}{ Period (July 1997 through June 1998) } \\
\hline & \multicolumn{2}{|c|}{$\begin{array}{c}\text { Summer } \\
\text { (July, Aug, Sept) }\end{array}$} & \multicolumn{2}{|c|}{$\begin{array}{c}\text { Fall } \\
\text { (Oct, Nov) }\end{array}$} & \multicolumn{2}{|c|}{$\begin{array}{c}\text { Winter } \\
\text { (Dec, Jan, Feb) }\end{array}$} & \multicolumn{2}{|c|}{$\begin{array}{c}\text { Spring } \\
\text { (Mar, Apr, May, June) }\end{array}$} \\
\hline & Grab & Composite & Grab & Composite & Grab & Composite & Grab & Composite \\
\hline $\begin{array}{l}\text { Nitrate (as N, ppb) } \\
\text { Number of samples } \\
\text { Mean } \\
\text { Standard Deviation } \\
\text { CV (\%) } \\
95 \% \text { UCL } \\
\text { 95\% UTL } \\
\end{array}$ & $\mathrm{NA}$ & $\begin{array}{c}13 \\
155.21 \\
33.38 \\
21.5 \\
173.8 \\
267.7 \\
\end{array}$ & NA & $\begin{array}{c}8 \\
144.09 \\
21.56 \\
15.0 \\
160.4 \\
229.0 \\
\end{array}$ & NA & $\begin{array}{c}13 \\
193.91 \\
57.75 \\
29.8 \\
227.6 \\
404.7 \\
\end{array}$ & NA & $\begin{array}{c}16 \\
224.07 \\
94.67 \\
42.2 \\
275.2 \\
573.8 \\
\end{array}$ \\
\hline $\begin{array}{l}\text { Sulfate (ppm) } \\
\text { Number of samples } \\
\text { Mean } \\
\text { Standard Deviation } \\
\text { CV (\%) } \\
95 \% \text { UCL } \\
95 \% \text { UTL } \\
\end{array}$ & $\mathrm{NA}$ & $\begin{array}{c}13 \\
14.50 \\
4.12 \\
28.4 \\
16.9 \\
29.3 \\
\end{array}$ & NA & $\begin{array}{c}8 \\
13.14 \\
1.14 \\
8.7 \\
14.0 \\
17.3 \\
\end{array}$ & NA & $\begin{array}{c}13 \\
10.92 \\
1.36 \\
12.4 \\
11.6 \\
15.1 \\
\end{array}$ & NA & $\begin{array}{c}16 \\
15.64 \\
5.03 \\
32.2 \\
18.2 \\
32.9 \\
\end{array}$ \\
\hline $\begin{array}{l}\text { Total Dissolved Solids (ppm) } \\
\text { Number of samples } \\
\text { Mean } \\
\text { Standard Deviation } \\
\text { CV (\%) } \\
95 \% \text { UCL } \\
95 \% \text { UTL } \\
\end{array}$ & NA & $\begin{array}{c}13 \\
89.41 \\
18.38 \\
20.6 \\
99.6 \\
150.8 \\
\end{array}$ & NA & $\begin{array}{c}8 \\
84.25 \\
12.05 \\
14.3 \\
93.3 \\
131.3 \\
\end{array}$ & NA & $\begin{array}{c}13 \\
95.88 \\
31.95 \\
33.3 \\
114.9 \\
216.3 \\
\end{array}$ & NA & $\begin{array}{c}16 \\
92.95 \\
24.04 \\
25.9 \\
104.9 \\
171.0 \\
\end{array}$ \\
\hline $\begin{array}{l}\text { Gross Alpha }(\mathrm{pCi} / \mathrm{L}) \\
\text { Number of samples } \\
\text { Mean } \\
\text { Standard Deviation } \\
\text { CV (\%) } \\
95 \% \text { UCL } \\
95 \% \text { UTL } \\
\end{array}$ & $\begin{array}{c}13 \\
1.33 \\
0.35 \\
26.2 \\
1.53 \\
2.6 \\
\end{array}$ & NA & $\begin{array}{c}8 \\
1.36 \\
0.36 \\
26.2 \\
1.66 \\
3.0 \\
\end{array}$ & NA & $\begin{array}{c}13 \\
1.19 \\
0.34 \\
28.8 \\
1.39 \\
2.4 \\
\end{array}$ & NA & $\begin{array}{c}16 \\
1.34 \\
0.40 \\
30.2 \\
1.55 \\
2.7 \\
\end{array}$ & NA \\
\hline $\begin{array}{l}\text { Gross Beta }(\mathrm{pCi} / \mathrm{L}) \\
\text { Number of samples } \\
\text { Mean } \\
\text { Standard Deviation } \\
\text { CV (\%) } \\
95 \% \text { UCL } \\
95 \% \text { UTL } \\
\end{array}$ & $\begin{array}{l}13 \\
1.51 \\
0.26 \\
17.0 \\
1.65 \\
2.3 \\
\end{array}$ & NA & $\begin{array}{c}8 \\
2.06 \\
1.40 \\
67.9 \\
3.77 \\
12.1 \\
\end{array}$ & NA & $\begin{array}{c}13 \\
1.30 \\
0.26 \\
20.2 \\
1.44 \\
2.2 \\
\end{array}$ & NA & $\begin{array}{c}16 \\
1.50 \\
0.44 \\
29.6 \\
1.72 \\
3.0 \\
\end{array}$ & NA \\
\hline
\end{tabular}


Table A-3. (contd)

\begin{tabular}{|c|c|c|c|c|c|c|c|c|}
\hline \multirow[b]{3}{*}{ Summary Statistics ${ }^{(a)}$} & \multicolumn{8}{|c|}{ Period (July 1998 through June 1999) } \\
\hline & \multicolumn{2}{|c|}{$\begin{array}{c}\text { Summer } \\
\text { (July, Aug, Sept) }\end{array}$} & \multicolumn{2}{|c|}{$\begin{array}{c}\text { Fall } \\
\text { (Oct, Nov) }\end{array}$} & \multicolumn{2}{|c|}{$\begin{array}{c}\text { Winter } \\
\text { (Dec, Jan, Feb) }\end{array}$} & \multicolumn{2}{|c|}{$\begin{array}{c}\text { Spring } \\
\text { (Mar, Apr, May, June) }\end{array}$} \\
\hline & Grab & Composite & Grab & Composite & Grab & Composite & Grab & Composite \\
\hline $\begin{array}{l}\text { Chloroform (ppb) } \\
\text { Number of samples } \\
\text { Mean } \\
\text { Standard Deviation } \\
\text { CV (\%) } \\
95 \% \text { UCL } \\
95 \% \text { UTL } \\
\end{array}$ & $\begin{array}{c}12 \\
5.89 \\
5.69 \\
96.7 \\
11.1 \\
39.1 \\
\end{array}$ & NA & $\begin{array}{c}8 \\
3.81 \\
2.03 \\
53.4 \\
6.0 \\
16.6 \\
\end{array}$ & NA & $\begin{array}{c}12 \\
4.47 \\
4.70 \\
105.1 \\
9.0 \\
32.6 \\
\end{array}$ & $\mathrm{NA}$ & $\begin{array}{c}17 \\
2.52 \\
2.81 \\
111.4 \\
4.4 \\
15.7 \\
\end{array}$ & NA \\
\hline $\begin{array}{l}\text { Total trihalomethanes (ppb) } \\
\text { Number of samples } \\
\text { Mean } \\
\text { Standard Deviation } \\
\text { CV (\%) } \\
95 \% \text { UCL } \\
95 \% \text { UTL } \\
\end{array}$ & $\begin{array}{c}12 \\
5.47 \\
3.25 \\
59.5 \\
7.9 \\
21.2 \\
\end{array}$ & NA & $\begin{array}{c}8 \\
3.97 \\
2.25 \\
56.6 \\
6.4 \\
18.5 \\
\end{array}$ & NA & $\begin{array}{c}12 \\
4.43 \\
3.32 \\
74.9 \\
7.1 \\
22.0 \\
\end{array}$ & NA & $\begin{array}{c}17 \\
2.58 \\
1.94 \\
75.2 \\
3.7 \\
10.9 \\
\end{array}$ & NA \\
\hline $\begin{array}{l}\text { Iron (ppb) } \\
\text { Number of samples } \\
\text { Mean } \\
\text { Standard Deviation } \\
\text { CV (\%) } \\
95 \% \text { UCL } \\
\text { 95\% UTL } \\
\end{array}$ & $\mathrm{NA}$ & $\begin{array}{c}12 \\
167.3 \\
152.8 \\
91.3 \\
303.5 \\
1,040.1 \\
\end{array}$ & NA & $\begin{array}{c}8 \\
146.1 \\
92.9 \\
63.6 \\
255.6 \\
790.0 \\
\end{array}$ & $\mathrm{NA}$ & $\begin{array}{c}12 \\
173.7 \\
82.4 \\
47.5 \\
230.6 \\
538.6 \\
\end{array}$ & $\begin{array}{l}1 \\
\text { NC } \\
\text { NC } \\
\text { NC } \\
\text { NC } \\
\text { NC }\end{array}$ & $\begin{array}{c}16 \\
165.2 \\
96.0 \\
58.1 \\
221.2 \\
556.8 \\
\end{array}$ \\
\hline $\begin{array}{l}\text { Manganese (ppb) } \\
\text { Number of samples } \\
\text { Mean } \\
\text { Standard Deviation } \\
\text { CV (\%) } \\
95 \% \text { UCL } \\
\text { 95\% UTL } \\
\end{array}$ & NA & $\begin{array}{l}12 \\
8.12 \\
5.26 \\
64.8 \\
12.2 \\
34.4\end{array}$ & NA & $\begin{array}{c}8 \\
5.66 \\
2.54 \\
44.9 \\
8.2 \\
20.3 \\
\end{array}$ & NA & $\begin{array}{c}12 \\
6.79 \\
3.08 \\
45.5 \\
8.9 \\
20.2 \\
\end{array}$ & $\begin{array}{l}1 \\
\text { NC } \\
\text { NC } \\
\text { NC } \\
\text { NC } \\
\text { NC }\end{array}$ & $\begin{array}{c}16 \\
7.43 \\
4.00 \\
53.9 \\
9.7 \\
23.4 \\
\end{array}$ \\
\hline $\begin{array}{l}\text { Chloride (ppm) } \\
\text { Number of samples } \\
\text { Mean } \\
\text {. Standard Deviation } \\
\text { CV (\%) } \\
95 \% \text { UCL } \\
\text { 95\% UTL } \\
\end{array}$ & $\mathrm{NA}$ & $\begin{array}{c}12 \\
5.11 \\
3.37 \\
65.9 \\
7.7 \\
22.1 \\
\end{array}$ & $\mathrm{NA}$ & $\begin{array}{c}8 \\
4.59 \\
0.85 \\
18.6 \\
5.3 \\
8.1 \\
\end{array}$ & NA & $\begin{array}{c}12 \\
5.34 \\
2.69 \\
50.4 \\
7.2 \\
17.5 \\
\end{array}$ & $\begin{array}{l}1 \\
\mathrm{NC} \\
\mathrm{NC} \\
\mathrm{NC} \\
\mathrm{NC} \\
\mathrm{NC} \\
\end{array}$ & $\begin{array}{c}16 \\
5.81 \\
3.40 \\
58.6 \\
7.8 \\
19.7 \\
\end{array}$ \\
\hline
\end{tabular}


Table A-3. (contd)

\begin{tabular}{|c|c|c|c|c|c|c|c|c|}
\hline \multirow[b]{3}{*}{ Summary Statistics ${ }^{(\mathrm{n})}$} & \multicolumn{8}{|c|}{ Period (July 1998 through June 1999) } \\
\hline & \multicolumn{2}{|c|}{$\begin{array}{c}\text { Summer } \\
\text { (July, Aug, Sept) }\end{array}$} & \multicolumn{2}{|c|}{$\begin{array}{c}\text { Fall } \\
\text { (Oct, Nov) }\end{array}$} & \multicolumn{2}{|c|}{$\begin{array}{c}\text { Winter } \\
(\mathrm{Dec}, \text { Jan, Feb) }\end{array}$} & \multicolumn{2}{|c|}{$\begin{array}{c}\text { Spring } \\
\text { (Mar, Apr, May, June) }\end{array}$} \\
\hline & Grab & Composite & Grab & Composite & Grab & Composite & Grab & Composite \\
\hline $\begin{array}{l}\text { Nitrate (as N, ppb) } \\
\text { Number of samples } \\
\text { Mean } \\
\text { Standard Deviation } \\
\text { CV (\%) } \\
95 \% \text { UCL } \\
\text { 95\% UTL. }\end{array}$ & NA & $\begin{array}{c}12 \\
144.59 \\
72.21 \\
49.9 \\
195.2 \\
470.4\end{array}$ & NA & $\begin{array}{c}8 \\
136.87 \\
119.85 \\
87.6 \\
313.2 \\
1,140.9\end{array}$ & NA & $\begin{array}{c}12 \\
159.29 \\
57.77 \\
36.3 \\
196.5 \\
391.8\end{array}$ & $\begin{array}{l}1 \\
\text { NC } \\
\text { NC } \\
\text { NC } \\
\text { NC } \\
\text { NC }\end{array}$ & $\begin{array}{c}16 \\
149.25 \\
62.59 \\
41.9 \\
183.0 \\
380.0\end{array}$ \\
\hline $\begin{array}{l}\text { Sulfate (ppm) } \\
\text { Number of samples } \\
\text { Mean } \\
\text { Standard Deviation } \\
\text { CV (\%) } \\
95 \% \text { UCL } \\
95 \% \text { UTL } \\
\end{array}$ & NA & $\begin{array}{c}12 \\
16.26 \\
4.42 \\
27.2 \\
18.9 \\
32.6 \\
\end{array}$ & NA & $\begin{array}{c}8 \\
19.26 \\
1.54 \\
8.0 \\
20.4 \\
24.8 \\
\end{array}$ & NA & $\begin{array}{c}12 \\
22.17 \\
5.76 \\
26.0 \\
25.6 \\
43.2 \\
\end{array}$ & $\begin{array}{l}1 \\
N C \\
N C \\
\text { NC } \\
\text { NC } \\
\text { NC }\end{array}$ & $\begin{array}{c}16 \\
21.62 \\
6.40 \\
29.6 \\
24.9 \\
43.1\end{array}$ \\
\hline $\begin{array}{l}\text { Total Dissolved Solids (ppm) } \\
\text { Number of samples } \\
\text { Mean } \\
\text { Standard Deviation } \\
\text { CV (\%) } \\
95 \% \text { UCL } \\
\text { 95\% UTL } \\
\end{array}$ & NA & $\begin{array}{c}12 \\
86.51 \\
25.63 \\
29.6 \\
102.3 \\
183.4 \\
\end{array}$ & $\mathrm{NA}$ & $\begin{array}{c}8 \\
90.77 \\
4.82 \\
5.3 \\
94.2 \\
107.4\end{array}$ & NA & $\begin{array}{c}12 \\
80.26 \\
17.57 \\
21.9 \\
90.6 \\
141.7\end{array}$ & $\begin{array}{l}1 \\
\mathrm{NC} \\
\mathrm{NC} \\
\mathrm{NC} \\
\mathrm{NC} \\
\mathrm{NC}\end{array}$ & $\begin{array}{c}16 \\
88.07 \\
39.24 \\
44.6 \\
109.5 \\
235.4\end{array}$ \\
\hline $\begin{array}{l}\text { Gross Alpha }(\mathrm{pCi} / \mathrm{L}) \\
\text { Number of samples } \\
\text { Mean } \\
\text { Standard Deviation } \\
\text { CV (\%) } \\
95 \% \text { UCL } \\
\text { 95\% UTL }\end{array}$ & $\begin{array}{l}12 \\
1.77 \\
1.05 \\
59.7 \\
2.55 \\
6.9\end{array}$ & NA & $\begin{array}{c}8 \\
1.59 \\
0.99 \\
62.5 \\
2.75 \\
8.4\end{array}$ & NA & $\begin{array}{l}7^{(f)} \\
1.36^{(f)} \\
0.67^{(f)} \\
49.6^{(f)} \\
2.15^{(f)} \\
6.0^{(f)}\end{array}$ & NA & $\begin{array}{c}17 \\
4.84 \\
7.04 \\
145.4 \\
10.44 \\
38.8\end{array}$ & NA \\
\hline $\begin{array}{l}\text { Gross Beta }(\mathrm{pCi} / \mathrm{L}) \\
\text { Number of samples } \\
\text { Mean } \\
\text { Standard Deviation } \\
\text { CV (\%) } \\
95 \% \text { UCL } \\
95 \% \text { UTL }\end{array}$ & $\begin{array}{c}12 \\
1.42 \\
0.35 \\
24.7 \\
1.63 \\
2.7\end{array}$ & NA & $\begin{array}{c}8 \\
1.63 \\
0.55 \\
34.1 \\
2.12 \\
3.8\end{array}$ & NA & $\begin{array}{c}12 \\
2.62 \\
2.07 \\
79.2 \\
4.35 \\
13.9\end{array}$ & NA & $\begin{array}{c}17 \\
1.28 \\
0.36 \\
28.5 \\
1.46 \\
2.5\end{array}$ & NA \\
\hline
\end{tabular}


Table A-3. (contd)

\begin{tabular}{|c|c|c|c|c|c|c|c|c|}
\hline \multirow[b]{3}{*}{ Summary Statistics ${ }^{(a)}$} & \multicolumn{8}{|c|}{ Period (July 1997 through June 1998) } \\
\hline & \multicolumn{2}{|c|}{$\begin{array}{c}\text { Summer } \\
\text { (July, Aug, Sept) }\end{array}$} & \multicolumn{2}{|c|}{$\begin{array}{c}\text { Fall } \\
\text { (Oct, Nov) }\end{array}$} & \multicolumn{2}{|c|}{$\begin{array}{c}\text { Winter } \\
\text { (Dec, Jan, Feb) }\end{array}$} & \multicolumn{2}{|c|}{$\begin{array}{c}\text { Spring } \\
\text { (Mar, Apr, May, June) }\end{array}$} \\
\hline & Grab & Composite & Grab & Composite & Grab & Composite & Grab & Composite \\
\hline \multirow[t]{4}{*}{$\begin{array}{l}\text { Arsenic }{ }^{(\mathrm{B})}(\mathrm{ppb}) \\
\text { Number of samples } \\
\text { Mean } \\
\text { Standard Deviation } \\
\text { CV (\%) } \\
95 \% \text { UCL } \\
95 \% \text { UTL } \\
\end{array}$} & NA & $\begin{array}{c}13 \\
0.59 \\
0.20 \\
34.2 \\
0.7 \\
1.4 \\
\end{array}$ & $\mathrm{NA}$ & $\begin{array}{c}8 \\
0.77 \\
0.28 \\
36.3 \\
1.0 \\
2.2 \\
\end{array}$ & NA & $\begin{array}{l}13 \\
0.81 \\
0.43 \\
52.8 \\
1.1 \\
2.7 \\
\end{array}$ & NA & $\begin{array}{c}16 \\
0.88 \\
0.55 \\
62.9 \\
1.2 \\
3.2 \\
\end{array}$ \\
\hline & \multicolumn{8}{|c|}{ Period (July 1998 through June 1999) } \\
\hline & \multicolumn{2}{|c|}{$\begin{array}{c}\text { Summer } \\
\text { (July, Aug, Sept) }\end{array}$} & \multicolumn{2}{|c|}{$\begin{array}{c}\text { Fall } \\
\text { (Oct, Nov) }\end{array}$} & \multicolumn{2}{|c|}{$\begin{array}{c}\text { Winter } \\
\text { (Dec, Jan, Feb) }\end{array}$} & \multicolumn{2}{|c|}{$\begin{array}{c}\text { Spring } \\
\text { (Mar, Apr, May, June) }\end{array}$} \\
\hline & Grab & Composite & Grab & Composite & Grab & Composite & Grab & Composite \\
\hline $\begin{array}{l}\text { Arsenic }^{(\mathrm{g})}(\mathrm{ppb}) \\
\text { Number of samples } \\
\text { Mean } \\
\text { Standard Deviation } \\
\text { CV (\%) } \\
95 \% \text { UCL } \\
95 \% \text { UTL } \\
\end{array}$ & NA & $\begin{array}{c}12 \\
1.56 \\
0.93 \\
59.9 \\
2.3 \\
6.1\end{array}$ & NA & $\begin{array}{c}8 \\
0.91 \\
0.20 \\
21.4 \\
1.1 \\
1.8 \\
\end{array}$ & NA & $\begin{array}{c}12 \\
0.67 \\
0.48 \\
71.6 \\
1.0 \\
3.1 \\
\end{array}$ & $\begin{array}{l}1 \\
\text { NC } \\
\text { NC } \\
\text { NC } \\
\text { NC } \\
\text { NC }\end{array}$ & $\begin{array}{c}16 \\
0.73 \\
0.33 \\
44.5 \\
0.9 \\
2.0\end{array}$ \\
\hline \multicolumn{9}{|c|}{$\begin{array}{l}\text { (a) Calculated based on assumed lognormal distribution (see WHC-SD-LEF-EV-001, Rev. 0, Appendix A). } \\
\text { (b) Excluded excursion occurred on April 7, } 1996 \text { (see WHC-SD-LEF-EV-001, Rev. 0, Appendix C). } \\
\text { (c) Outlier (July 6, 1995) removed. } \\
\text { (d) Excluded anomalous data (collected prior to October 23, 1995) due to a one-time PUREX release. } \\
\text { (e) Excluded excursion occurred on January 12, 1997. } \\
\text { (f) Excluded anomalous data (collected from January 22, } 1999 \text { to February 17, 1999) due to a PFP release. } \\
\text { (g) Summary statistics not calculated for period covered from July } 1995 \text { through June } 1997 \text { (most data were non-detects). }\end{array}$} \\
\hline
\end{tabular}


Table A-4. Probability of Exceeding Average Monthly Concentration for TEDF Detected Constituents Under Normal Operating Conditions

\begin{tabular}{|c|c|c|c|c|c|}
\hline Parameter & Summer & Fall & Winter & Spring & Overall \\
\hline \multicolumn{6}{|c|}{ Chloroform: Grab Sample Results (ppb) } \\
\hline $\begin{array}{l}\text { Permit limit }{ }^{(a)} \\
\text { Number of Observations } \\
\text { Average } \\
\text { Standard Deviation } \\
\text { Minimum } \\
\text { Maximum } \\
\text { Exceedance Probability }{ }^{(b)}\end{array}$ & $\begin{array}{c}66 \\
12 \\
7.1 \\
3.87 \\
0.95 \\
14 \\
\cong 0 \\
\end{array}$ & $\begin{array}{c}66 \\
8 \\
3.75 \\
2.67 \\
0.9 \\
8.25 \\
\cong 0\end{array}$ & $\begin{array}{c}66 \\
12 \\
2.57 \\
2.02 \\
0 \\
5.6 \\
\cong 0\end{array}$ & $\begin{array}{c}66 \\
16 \\
4.54 \\
3.25 \\
1.05 \\
12.5 \\
\cong 0\end{array}$ & $\begin{array}{c}66 \\
48 \\
4.56 \\
3.41 \\
0 \\
14 \\
\cong 0\end{array}$ \\
\hline \multicolumn{6}{|c|}{ Total Trihalomethanes: Grab Sample Results (ppb) } \\
\hline $\begin{array}{l}\text { Permit limit } \\
\text { Number of Observations } \\
\text { Average } \\
\text { Standard Deviation } \\
\text { Minimum } \\
\text { Maximum } \\
\text { Exceedance Probability }{ }^{(b)}\end{array}$ & $\begin{array}{c}66 \\
9 \\
5.93 \\
3.43 \\
0.95 \\
13 \\
\cong 0\end{array}$ & $\begin{array}{c}66 \\
6 \\
2.58 \\
1.56 \\
0.9 \\
4.55 \\
\cong 0\end{array}$ & $\begin{array}{c}66 \\
10 \\
2.24 \\
1.94 \\
0 \\
5.4 \\
\cong 0\end{array}$ & $\begin{array}{l}66 \\
16 \\
4.66 \\
3.18 \\
1.54 \\
12.5 \\
\cong 0\end{array}$ & $\begin{array}{c}66 \\
41 \\
4.05 \\
3.06 \\
0 \\
13 \\
\cong 0\end{array}$ \\
\hline \multicolumn{6}{|c|}{ Iron $^{(\mathrm{c})}$ : Composite Sample Results (ppb) } \\
\hline $\begin{array}{l}\text { Permit limit } \\
\text { Number of Observations } \\
\text { Average } \\
\text { Standard Deviation } \\
\text { Minimum } \\
\text { Maximum } \\
\text { Exceedance Probability }\end{array}$ & $\begin{array}{c}258 \\
12 \\
95.9 \\
66.76 \\
25.6 \\
224.68 \\
0.0076 \\
\end{array}$ & $\begin{array}{c}258 \\
8 \\
83.21 \\
50.5 \\
33.75 \\
194.25 \\
0.0003 \\
\end{array}$ & $\begin{array}{c}258 \\
12 \\
112.4 \\
43.85 \\
41.8 \\
205 \\
0.0004 \\
\end{array}$ & $\begin{array}{c}258 \\
16 \\
137.51 \\
48.24 \\
70.5 \\
254 \\
0.0063 \\
\end{array}$ & $\begin{array}{c}258 \\
48 \\
111.78 \\
55.18 \\
25.6 \\
254 \\
0.004\end{array}$ \\
\hline \multicolumn{6}{|c|}{ Manganese $e^{(c)}:$ Composite Sample Results (ppb) } \\
\hline $\begin{array}{l}\text { Permit limit } \\
\text { Number of Observations } \\
\text { Average } \\
\text { Standard Deviation } \\
\text { Minimum } \\
\text { Maximum } \\
\text { Exceedance Probability }^{(b)}\end{array}$ & $\begin{array}{c}50 \\
12 \\
6.4 \\
2.44 \\
4 \\
11.58 \\
\cong 0 \\
\end{array}$ & $\begin{array}{c}50 \\
8 \\
6.06 \\
2.25 \\
4 \\
11 \\
\cong 0\end{array}$ & $\begin{array}{c}50 \\
12 \\
5.74 \\
1.39 \\
4.55 \\
9.26 \\
\cong 0\end{array}$ & $\begin{array}{c}50 \\
16 \\
7.18 \\
4.86 \\
4.4 \\
23.9 \\
\cong 0\end{array}$ & $\begin{array}{c}50 \\
48 \\
6.44 \\
3.24 \\
4 \\
23.9 \\
\cong 0\end{array}$ \\
\hline \multicolumn{6}{|c|}{ Arsenic ${ }^{(d)}:$ Composite Sample Results (ppb) } \\
\hline $\begin{array}{l}\text { Permit limit } \\
\text { Number of Observations } \\
\text { Average } \\
\text { Standard Deviation } \\
\text { Minimum } \\
\text { Maximum } \\
\text { Exceedance Probability }{ }^{(b)}\end{array}$ & $\begin{array}{l}15 \\
9 \\
1.44 \\
1.00 \\
0.56 \\
3.63 \\
\cong 0\end{array}$ & $\begin{array}{c}15 \\
6 \\
0.77 \\
0.19 \\
0.43 \\
1 \\
\cong 0\end{array}$ & $\begin{array}{l}15 \\
9 \\
0.72 \\
0.27 \\
0.4 \\
1.23 \\
\cong 0\end{array}$ & $\begin{array}{l}15 \\
15 \\
0.81 \\
0.34 \\
0.4 \\
1.5 \\
\cong 0\end{array}$ & $\begin{array}{c}15 \\
39 \\
0.93 \\
0.60 \\
0.4 \\
3.63 \\
\cong 0\end{array}$ \\
\hline
\end{tabular}


Table A-4. (contd)

\begin{tabular}{|c|c|c|c|c|c|}
\hline Parameter & Summer & Fall & Winter & Spring & Overal \\
\hline \multicolumn{6}{|c|}{ Lead $^{(\mathrm{d})}:$ Composite Sample Results (ppb) } \\
\hline $\begin{array}{l}\text { Permit limit }{ }^{(e)} \\
\text { Number of Observations } \\
\text { Average } \\
\text { Standard Deviation } \\
\text { Minimum } \\
\text { Maximum } \\
\text { Exceedance Probability }{ }^{(b)}\end{array}$ & $\begin{array}{c}10 \\
9 \\
0.61 \\
0.36 \\
0.2 \\
1.35 \\
\cong 0\end{array}$ & $\begin{array}{c}10 \\
6 \\
0.36 \\
0.20 \\
0.2 \\
0.74 \\
\cong 0\end{array}$ & $\begin{array}{c}10 \\
9 \\
0.45 \\
0.25 \\
0.23 \\
1.03 \\
\cong 0\end{array}$ & $\begin{array}{c}10 \\
15 \\
0.66 \\
0.49 \\
0.2 \\
1.88 \\
\cong 0\end{array}$ & $\begin{array}{c}10 \\
39 \\
0.56 \\
0.39 \\
0.2 \\
1.88 \\
\cong 0 \\
\end{array}$ \\
\hline \multicolumn{6}{|c|}{ Chloride: Composite Sample Results (ppm) } \\
\hline $\begin{array}{l}\text { Permit limit } \\
\text { Number of Observations } \\
\text { Average } \\
\text { Standard Deviation } \\
\text { Minimum } \\
\text { Maximum } \\
\text { Exceedance Probability }^{(b)}\end{array}$ & $\begin{array}{c}58 \\
12 \\
5.95 \\
3.85 \\
2.07 \\
14.96 \\
\cong 0\end{array}$ & $\begin{array}{c}58 \\
8 \\
9.42 \\
10.12 \\
1.53 \\
28.93 \\
0.000001\end{array}$ & $\begin{array}{c}58 \\
12 \\
6.44 \\
5.12 \\
1.46 \\
18.75 \\
\cong 0\end{array}$ & $\begin{array}{c}58 \\
16 \\
6.55 \\
5.30 \\
2.06 \\
21.69 \\
\cong 0\end{array}$ & $\begin{array}{c}58 \\
48 \\
6.85 \\
5.94 \\
1.46 \\
28.93 \\
\cong 0\end{array}$ \\
\hline \multicolumn{6}{|c|}{ Nitrate (as N): Composite Sample Results (ppb) } \\
\hline $\begin{array}{l}\text { Permit limit } \\
\text { Number of Observations } \\
\text { Average } \\
\text { Standard Deviation } \\
\text { Minimum } \\
\text { Maximum } \\
\text { Exceedance Probability }{ }^{(b)}\end{array}$ & $\begin{array}{c}620 \\
12 \\
165.78 \\
76.56 \\
57 \\
322.8 \\
\cong 0\end{array}$ & $\begin{array}{c}620 \\
8 \\
146.38 \\
44.54 \\
98 \\
242.4 \\
\cong 0\end{array}$ & $\begin{array}{c}620 \\
12 \\
178.8 \\
26.58 \\
140 \\
236 \\
\cong 0\end{array}$ & $\begin{array}{c}620 \\
16 \\
201.2 \\
76.62 \\
105.5 \\
392.5 \\
\cong 0\end{array}$ & $\begin{array}{c}620 \\
48 \\
177.61 \\
64.01 \\
57 \\
392.5 \\
\cong 0\end{array}$ \\
\hline \multicolumn{6}{|c|}{ Sulfate ${ }^{(\mathrm{s})}$ : Composite Sample Results (ppm) } \\
\hline $\begin{array}{l}\text { Drinking Water Standard }^{(f)} \\
\text { Number of Observations } \\
\text { Average } \\
\text { Standard Deviation } \\
\text { Minimum } \\
\text { Maximum } \\
\text { Exceedance Probability }{ }^{(b)}\end{array}$ & $\begin{array}{c}250 \\
12 \\
13.61 \\
2.57 \\
9.24 \\
18.17 \\
\cong 0\end{array}$ & $\begin{array}{c}250 \\
8 \\
13.56 \\
3.82 \\
8.98 \\
20.48 \\
\cong 0\end{array}$ & $\begin{array}{c}250 \\
12 \\
13.18 \\
5.50 \\
8.63 \\
23.55 \\
\cong 0\end{array}$ & $\begin{array}{c}250 \\
16 \\
17.46 \\
5.43 \\
11.32 \\
25.49 \\
\cong 0\end{array}$ & $\begin{array}{c}250 \\
48 \\
14.78 \\
4.89 \\
8.63 \\
25.49 \\
\cong 0\end{array}$ \\
\hline \multicolumn{6}{|c|}{ Total Dissolved Solids: Composite Sample Results (ppb) } \\
\hline $\begin{array}{l}\text { Permit limit }{ }^{(\mathfrak{l})} \\
\text { Number of Observations } \\
\text { Average } \\
\text { Ständard Deviation } \\
\text { Minimum } \\
\text { Maximum } \\
\text { Exceedance Probability(b) }\end{array}$ & $\begin{array}{l}250 \\
12 \\
80.95 \\
20.67 \\
38 \\
115 \\
\cong 0\end{array}$ & $\begin{array}{c}250 \\
8 \\
90.88 \\
17.61 \\
64 \\
125 \\
\cong 0\end{array}$ & $\begin{array}{c}250 \\
12 \\
77.01 \\
20.34 \\
49.8 \\
131.5 \\
\cong 0\end{array}$ & $\begin{array}{c}250 \\
16 \\
93.29 \\
19.43 \\
64.2 \\
127 \\
\cong 0\end{array}$ & $\begin{array}{c}250 \\
48 \\
85.73 \\
20.32 \\
38 \\
131.5 \\
\cong 0\end{array}$ \\
\hline
\end{tabular}


Table A-4.(contd)

\begin{tabular}{|c|c|c|c|c|c|}
\hline Parameter & Summer & Fall & Winter & Spring & Overall \\
\hline \multicolumn{6}{|c|}{ Gross Alpha $a^{(2)}:$ Grab Sample Results (pCi/L) } \\
\hline $\begin{array}{l}\text { Drinking Water Standard } \\
\text { Number of Observations } \\
\text { Average } \\
\text { Standard Deviation } \\
\text { Minimum } \\
\text { Maximum } \\
\text { Exceedance Probability }\end{array}$ & $\begin{array}{c}15 \\
12 \\
1.22 \\
0.62 \\
0.34 \\
2.53 \\
\cong 0 \\
\end{array}$ & $\begin{array}{c}15 \\
8 \\
1.07 \\
0.57 \\
0.26 \\
1.98 \\
\cong 0 \\
\end{array}$ & $\begin{array}{c}15 \\
12 \\
1.28 \\
0.98 \\
0.37 \\
4.07 \\
\cong 0 \\
\end{array}$ & $\begin{array}{c}15 \\
16 \\
2.09 \\
1.99 \\
0.94 \\
7.45 \\
\cong 0 \\
\end{array}$ & $\begin{array}{l}15 \\
48 \\
1.50 \\
1.34 \\
0.26 \\
7.45 \\
\cong 0 \\
\end{array}$ \\
\hline \multicolumn{6}{|c|}{ Gross Beta $^{(\mathrm{b})}$ : Grab Sample Results (pCi/L) } \\
\hline $\begin{array}{l}\text { Drinking Water Standard }{ }^{(\mathfrak{l})} \\
\text { Number of Observations } \\
\text { Average } \\
\text { Standard Deviation } \\
\text { Minimum } \\
\text { Maximum } \\
\text { Exceedance Probability }{ }^{(b)}\end{array}$ & $\begin{array}{c}50 \\
9 \\
1.30 \\
0.33 \\
0.68 \\
1.73 \\
\cong 0\end{array}$ & $\begin{array}{c}50 \\
8 \\
1.57 \\
0.53 \\
0.79 \\
2.26 \\
\cong 0\end{array}$ & $\begin{array}{c}50 \\
12 \\
1.56 \\
0.97 \\
0.5 \\
4.33 \\
\cong 0\end{array}$ & $\begin{array}{c}50 \\
16 \\
1.50 \\
0.39 \\
0.92 \\
2.31 \\
\cong 0\end{array}$ & $\begin{array}{c}50 \\
45 \\
1.49 \\
0.60 \\
0.50 \\
4.33 \\
\cong 0\end{array}$ \\
\hline \multicolumn{6}{|c|}{$\begin{array}{l}\text { (a) Early warning value in effluent for total trihalomethanes is used. } \\
\text { (b) Exceedance probability } \cong 0 \text { means }<10^{-6} \text { (or less than } 1 \text { in one million). } \\
\text { (c) Excluded April 7, } 1996 \text { and January } 12,1997 \text { excursions for iron and manganese; excluded April 7, } 1996 \\
\text { excursion for sulfate. } \\
\text { (d) Data from April } 21,1996 \text { and later (prior to April } 21,1996 \text { arsenic and lead data are essentially not detected). } \\
\text { (e) Early warning value in effluent of } 10 \mathrm{ppb} \text { is used. } \\
\text { (f) No applicable permit limit, the limit used is based on WAC } 173-200 \text { groundwater quality standard. } \\
\text { (g) Excluded anomalous data collected between January } 22,1999 \text { to February } 10,1999 \text { due to release from PFP. } \\
\text { (h) Excluded anomalous data collected prior to October 22, } 1995 \text { due to a one time release from PUREX. }\end{array}$} \\
\hline
\end{tabular}


Appendix B .

Graphical Display of Effluent Monitoring Data 


\section{Appendix B}

\section{Graphical Display of Effluent Monitoring Data}

This appendix includes time series plots and box and whisker plots of effluent monitoring data for the detected constituents. The figures are intended to stand alone. However, explanatory notes are added where appropriate. The main text can also be used for additional discussion that may clarify the graphical displays and indicate caveats of the data presented.

Continuous monitoring data (flow rate, specific conductivity, and $\mathrm{pH}$ ) are presented first (Figures $\mathrm{B}-1$ through B-3). Time versus concentration plots for detected constituents based on individual grab and/or composite samples are present next (Figures B-4 through B-12) followed by the monthly averages (Figures B-13 through B-21). The presence of temporal cycles (seasonality) was examined visually by using multiple box and whisker plots (Figures B-22 through B-30) where the distribution of effluent concentrations (for a particular constituent) over different seasons is displayed. Similarly, it was used to examine the effect of sample types (grab versus composite) on effluent concentrations (Figure B-31 through B-38).

In a box and whisker plot, the upper $\left(\mathrm{Q}_{3}\right)$ and lower $\left(\mathrm{Q}_{1}\right)$ quarters of the data are shown by the top and bottom of a box and the median $\left(\mathrm{Q}_{2}\right)$ is indicated by a line segment within the box. The box covers the middle 50 percent of the data values. The 'whiskers' extend out to the extremes (minimum and maximum observations). When extremely large or small values occur, these values are plotted as individual points. The whiskers extend only to those points that are within 1.5 times the interquartile range, $I Q R\left(Q_{3}-Q_{1}\right)$. The median and IQR are analogous to the more common mean and standard deviation of a data set. The median is a measure of 'central tendency' or 'location,' whereas the IQR is a measure of 'variability.' Any data point that falls outside the whisker could be classified as a suspected outlier (Ostle and Malone 1988).

It should be noted that within each data display category, volatile organic compound is shown first, followed by metals, anions, other analysis, and radionuclides. Also, anomalous data that correlated to excursions (e.g., iron exceedances observed on April 7, 1996 and January 12, 1997) were not used in the multiple box and whisker plots depicting seasonal effects. Their inclusion would make the range covered by the vertical concentration scale so large that the seasonal effects would not be discernable. Additionally, only individual grab and composites samples collected for the variability study (from July 1995 through June 1996) are used to generate the box and whisker plots depicting possible sample type effects (Figures B-31 through B-38). This is because after June 1996 only one type of samples was collected and analyzed for the constituent of interest. Finally, the specific conductivity and $\mathrm{pH}$ data are subject to a flow rate limitation. When the flow rate drops below $50 \mathrm{gpm}$, water from the effluent stream can no 
longer flow through the measurement cell. Thus during very low flow periods, the values recorded are for stagnant water in the cell and do not reflect ambient conditions in the effluent stream. This is a problem that is under study.

Explanatory notes and a brief discussion of the salient features of the concentration versus time plots and the box and whisker plots are as follows.

\section{Figure B-1}

The marked change in flow conditions after 1997 is due to evaporator campaigns that last for a few days to a week or two. The high flow rates are required to cool the evaporator condensers. The specific conductance of effluent during the high flow periods is similar to Columbia River water $(140 \mu \mathrm{S} / \mathrm{cm})$.

\section{Figure B-2}

Most of the large peaks are due to calibration problems. Also, during low flow (<50 gpm) the conductivity and $\mathrm{pH}$ probes are immersed in stagnant water. This is because the monitoring system requires at least $50 \mathrm{gpm}$ to ensure water flows through the measurement cell. Most of the readings shown cluster around the average or typical river water value of $140 \mu \mathrm{S} / \mathrm{cm}$.

\section{Figure B-3}

The same caveats concerning low flow conditions apply to $\mathrm{pH}$ as well as conductivity. The most common or most frequent values are in the range of typical river water.

\section{Figure B-4}

The original variability study (Chou and Johnson 1996) indicated that the minima during the winter and fall and maxima during spring and summer are readily recognizable as illustrated in the box and whisker plots in Figure B-22. However, there also appears to be an overall trend of declining chloroform concentrations during the 4-year period of record.

\section{Figure B-5}

The random spike occurrences of iron are readily apparent. The general trend, however, appears to be for spikes or excursions that are smaller in magnitude during 1998 and 1999 than in previous years. Grab samples and composite samples are shown together for comparison. In most cases, the grab samples and 24-hour composite samples are comparable.

\section{Figure B-6}

Manganese is not detected much of the time as indicated by a line corresponding to the method detection limit ( $\sim 4.4 \mathrm{ppb})$. Manganese, a co-variate with iron, exhibits the same spike occurrences as iron and probably has a similar origin (rusting carbon steel pipe). The grabs and 24-hour composites are comparable. 


\section{Figure B-7}

The short term or spike occurrences for chloride have clearly been attenuated since 1998 . This is due to elimination of the water softeners associated with the old 200 Areas Power Plants that were shut down in 1998. The grab samples and composite samples both reflected the excursion that occurred February 6 , 1996.

\section{Figure B-8}

In general, the grab samples and composite samples are comparable for this constituent: As with several other detected constituents, nitrate appears to have declined since 1998. The cyclic nature of the concentrations is also evident in this plot. The highest concentrations shown are far below the drinking water standard $(10,000 \mathrm{ppb}$ as $N)$ even though the daily maximum limit is only $1,240 \mathrm{ppb}$.

\section{Figure B-9}

Grab samples and composite samples seem to be generally comparable. Overall there appears to be a gradual upward trend over the last two years. Nevertheless, the average concentrations are not much higher than the average Columbia River water of $11 \mathrm{mg} / \mathrm{L}$ and are well below either the drinking water standard or the permit limits.

\section{Figure B-10}

Total dissolved solids (TDS) is equivalent to conductivity. The overall pattern is similar to chloride that has been a dominant contributor to TDS in the past. Grab samples and 24-hour composite samples also seem to track each other fairly closely.

\section{Figure B-11}

Grab sample results for gross alpha track well with composite samples. Except for the excursion January 22, 1999, and for a short period thereafter, gross alpha is consistently close to the natural background for Columbia River water. The excursion in 1999 was attributed to breakthrough of treatment columns at the Plutonium Finishing Plant (PFP) water treatment plant.

\section{Figure B-12}

As noted for gross alpha, grab and composite samples for gross beta yield similar results. Except for an early excursion due to strontium-90, gross beta is consistently near the natural background level of river water. The consistent and low background levels for both gross alpha and gross beta make these constituents good overall indicators for alpha and beta emitters. 


\section{Figure B-13}

The monthly average for chloroform reflects the same general trend as the grab samples except the variability is greatly attenuated. The average is well below the early warning value in effluent (set for total trihalomethanes).

\section{Figure B-14}

The highest allowable monthly average of $258 \mathrm{ppb}$ was exceeded twice during the 4-year monitoring period (July 1995 through June 1996). The monthly averaging process also greatly smoothes the individual data for total iron as illustrated by comparing this plot with Figure B-5. There is a close correspondence between the grab and composite sample data.

\section{Figure B-15}

The averaging process has the same effect on manganese as on iron and chloroform. Likewise, the grabs and composite averages are in good agreement.

\section{Figure B-16}

The monthly averaging process also attenuates the chloride concentrations (see Figure B-7). However, the monthly averages of grab and composite samples appear to be out of phase with each other during the first year of operation. This may be a result of frequent spike occurrences that were "captured" by the 24-hour composite sample but not by the grab samples. Also, the effect of reduced input of chloride beginning in 1998 (200 Areas Power Plant shutdown) is clearly evident in comparison to the previous three years.

\section{Figure B-17}

The cyclic nature of nitrate is clearly evident in the monthly average data as shown in this plot. Grab samples and composite samples are also in good agreement.

\section{Figure B-18}

In contrast to chloride, the monthly averages of grab and composite sample results are in close agreement for sulfate. As with the other constituents, averaging smoothes the data and makes the cyclic trends more recognizable.

\section{Figure B-19}

The monthly averaging process smoothed the TDS results as with the other constituents. Grab and composite sample data are in agreement as noted for sulfate. 


\section{. Figure B-20}

The monthly averaging process did not alter gross alpha very much because the individual weekly samples did not exhibit much variability.

\section{Figure B-21}

As with gross alpha, the monthly averaging of individual weekly data for this constituent did not have much of an effect because it was so consistent (excluding the initial excursion).

\section{Figure B-22}

The box plots for the complete 4-year data set, segregated by season, indicate there are lower concentrations in fall and winter and higher concentrations in spring and summer. This has been attributed to enhanced chlorination of organics produced by phytoplankton during the annual maxima in their growth cycle. The spread in the data (range of concentrations) is in part due to the overall decline in concentrations during 1998 and 1999.

\section{Figure B-23}

The anomalously high iron values that exceeded the permit standard are shown as $+\mathrm{s}$. The median concentrations are slightly higher in winter and spring. Also, variability is larger in the winter and spring seasons.

\section{Figure B-24}

In contrast to iron, the manganese box plots suggest there is a high concentration group co-mingled with a low concentration group that has a very narrow range (flattened boxes). The low concentration group represents data that were near and/or at the detection limit (see Figure B-6). The higher concentration could be a result of the hypothesized occurrence of particulate releases from rusting cast iron pipe.

\section{Figure B-25}

Chloride exhibits a bimodal population as noted in the initial variability study report (Chou and Johnson 1996). There appears to be two chloride populations: (1) a large group of typically low concentrations (172 out of total 200 analyses) that occur over a rather narrow range ( $<10 \mathrm{ppm}$ ) with most samples (134 sample) between 1 to $5 \mathrm{ppm}$; and (2) a smaller group consisting of much higher concentrations scattered over a wide range (up to $85.2 \mathrm{ppm}$ ). The higher concentration group ( $\geq 10 \mathrm{ppm}$ ) is attributed to periodic (random) regeneration of resin beds for water softeners at the old power plants. The low concentration population is close to the natural background of river water. 


\section{Figure B-26}

The seasonal variation (highest median concentrations in winter and spring) is evident for nitrate. This pattern is shifted from the chloroform maxima that occur in spring and summer.

\section{Figure B-27}

The most noticeable feature for sulfate is the apparent larger variability and higher concentration in composite samples collected during the spring season. The " $+\mathrm{s}$ " shown outside the box plot for winter correspond to samples collected during January and February of 1999 (see Figure B-9)

\section{Figure B-28}

Total dissolved solids tend to follow the same seasonal pattern as sulfate, with lowest concentration median occurring in winter and higher median concentration in spring.

\section{Figure B-29}

There appears to be a seasonal effect for the gross alpha data with lower concentration in winter and higher concentration in spring. The narrow widths of the boxes for gross alpha indicate a relatively low variability over all seasons. The outliers $(+s)$ shown for spring are due to a treatment column operational problem at the PFP that occurred only in 1999.

\section{Figure B-30}

There does not appear to be a seasonal component in the gross beta data. The outliers $(+s)$ shown outside of the box plot for winter could be related to the PFP release that occurred during January 1999.

\section{Figure B-31}

The grab and composite samples yield similar results. The highest concentration shown as + in the composite $(3,100 \mathrm{ppb})$ as well as grab sample $(1,850 \mathrm{ppb})$ corresponded to the event occurred on April 7 , 1996 where permit limit was exceeded.

\section{Figure B-32}

Manganese in the 24-hour composite and grab samples are similar. Both indicate a low concentration group (boxes) which are comprised primarily of non-detects, and a population of higher concentrations that occur as random spikes (co-variate with iron).

\section{Figure B-33}

Both grab samples and composite samples for chloride exhibit similar distributions (bimodal, see discussion in Figure B-25). 


\section{Figure B-34}

Both grab and composite samples for nitrate yield similar results (similar in median concentration and variability).

\section{Figure B-35}

Both grab and composite samples for sulfate yield similar results (similar in median concentration and variability).

\section{Figure B-36}

Both grab and composite samples for total dissolved solids yield similar results. Larger variability as shown for the grab samples were due to fewer data ( 8 observations) points.

\section{Figure B-37}

Both grab and composite samples for gross alpha yield similar results (similar in median concentration and variability).

\section{Figure B-38}

Both grab samples and composite samples yield similar results for gross beta. The outliers (shown as $+s$ outside of the boxes) were excursion due to strontium- 90 of one time release from PUREX.

\section{B.1 References}

Chou and Johnson. 1996. Effluent Variability Study Results for the 200 Area Treated Effluent Disposal Facility. WHC-SD-LEF-EV-001, Rev. 0, Westinghouse Hanford Company, Richland, Washington.

Ostle and Malone. 1988. Statistics in Research, fourth edition, Iowa State University Press, Ames, Iowa, pp. 66-67. 


\section{Continuous Monitoring Data}

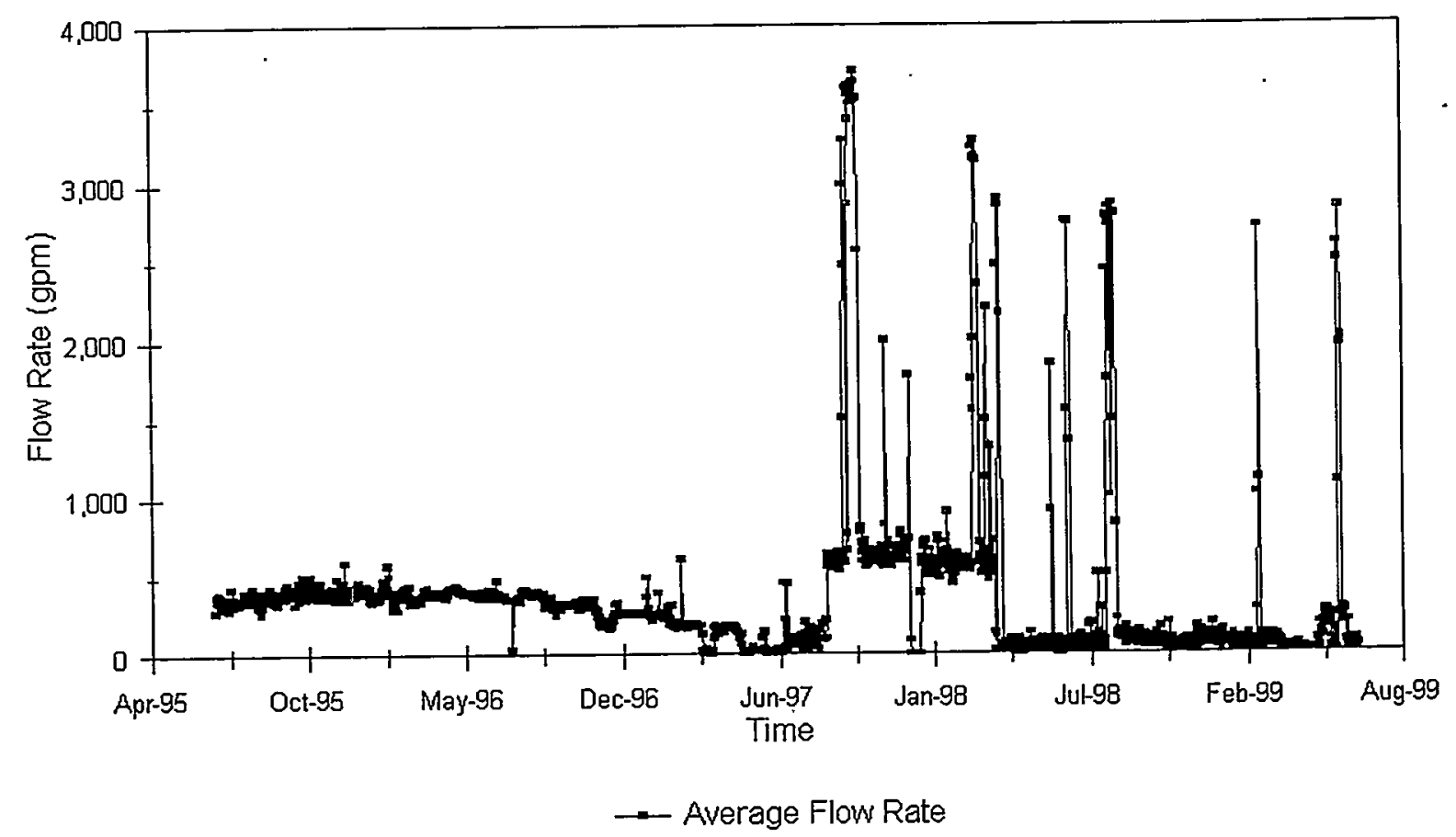

Figure B-1. TEDF Continuous Data - Average Daily Rate Flow Rate

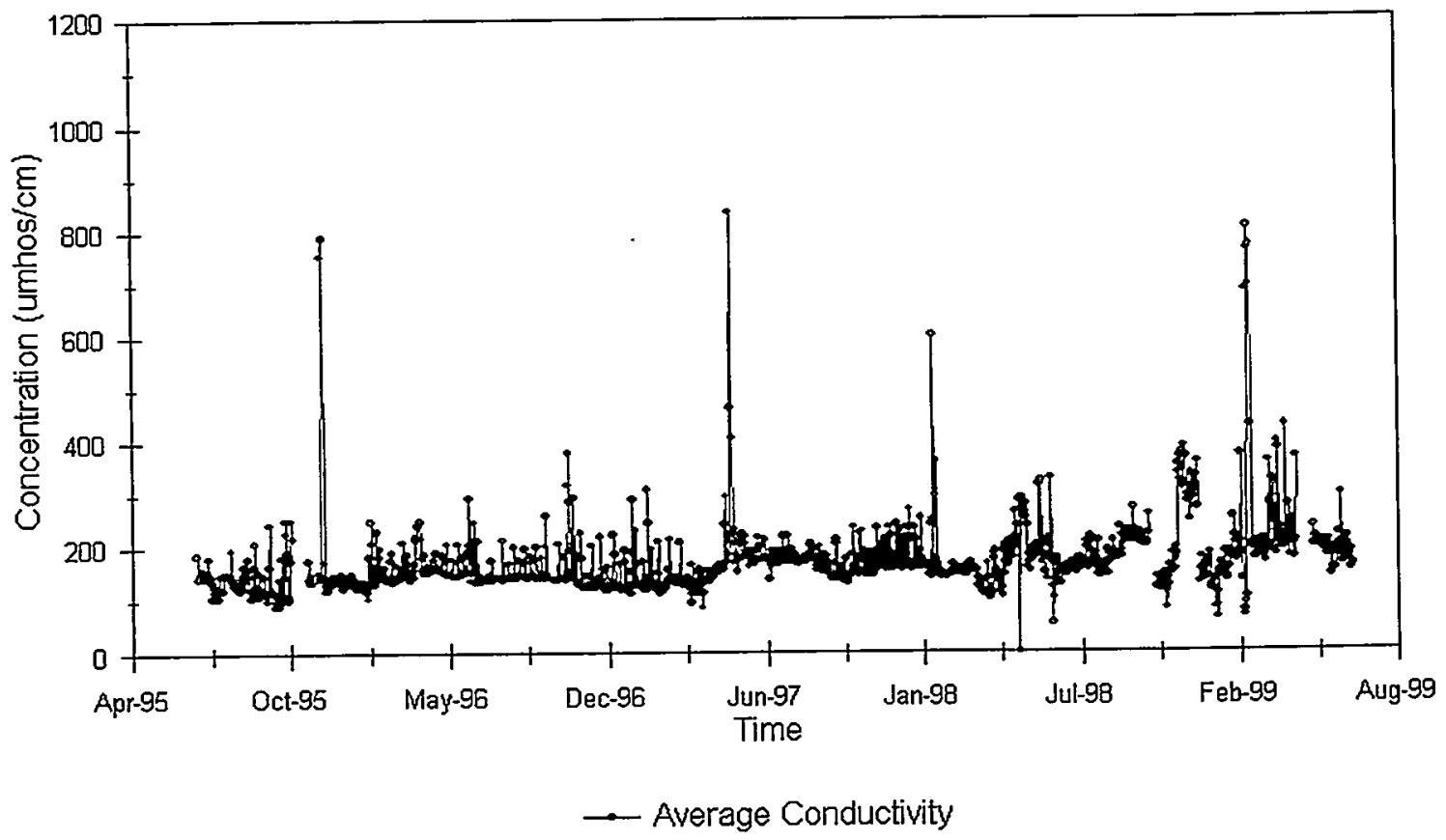

Figure B-2. TEDF Continuous Monitoring Data - Average Daily Specific Conductivity 


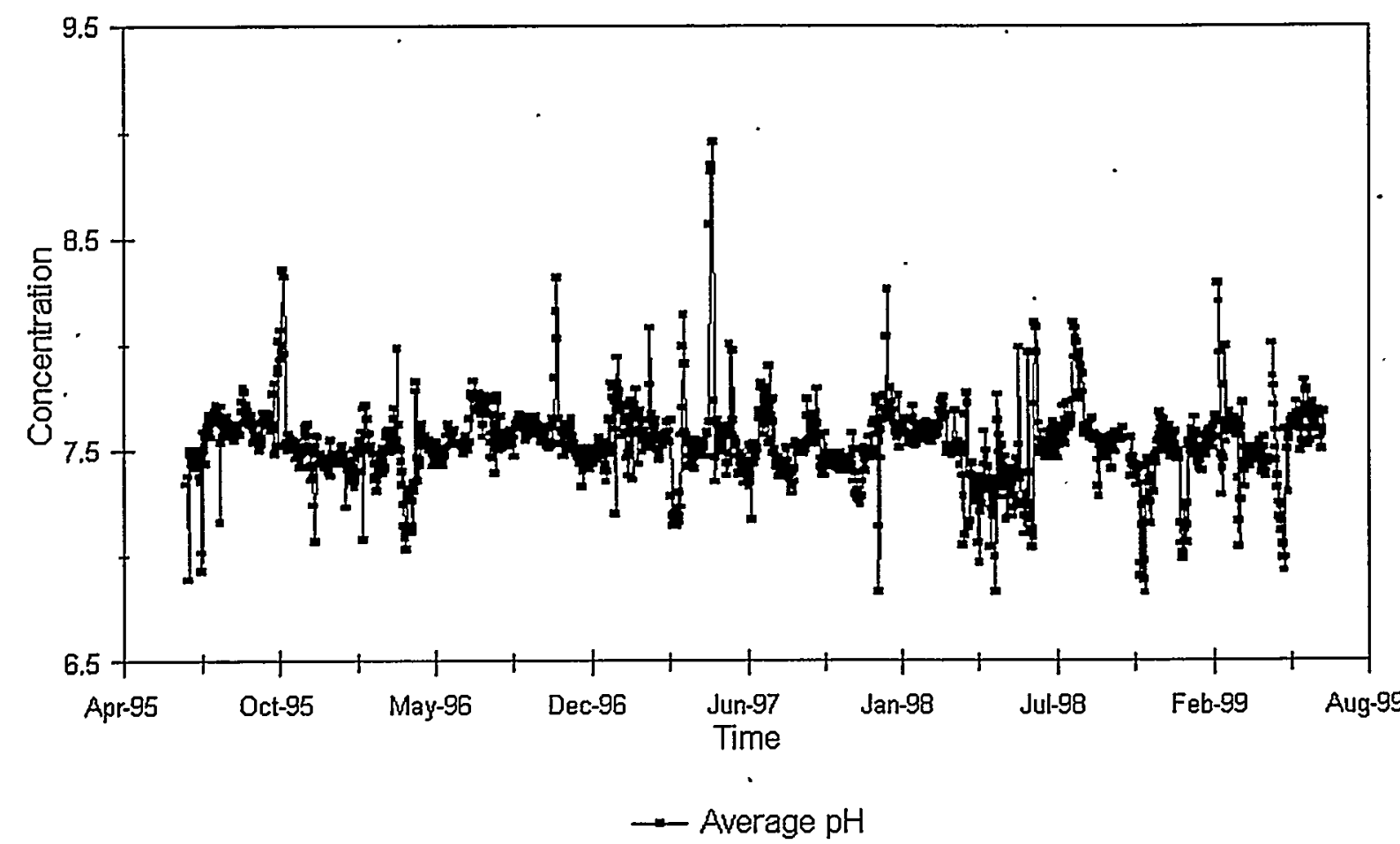

Figure B-3. TEDF Continuous Monitoring Data - Average Daily pH 
Time Versus Concentration Plots - Weekly Grab and/or Composite Sample Results

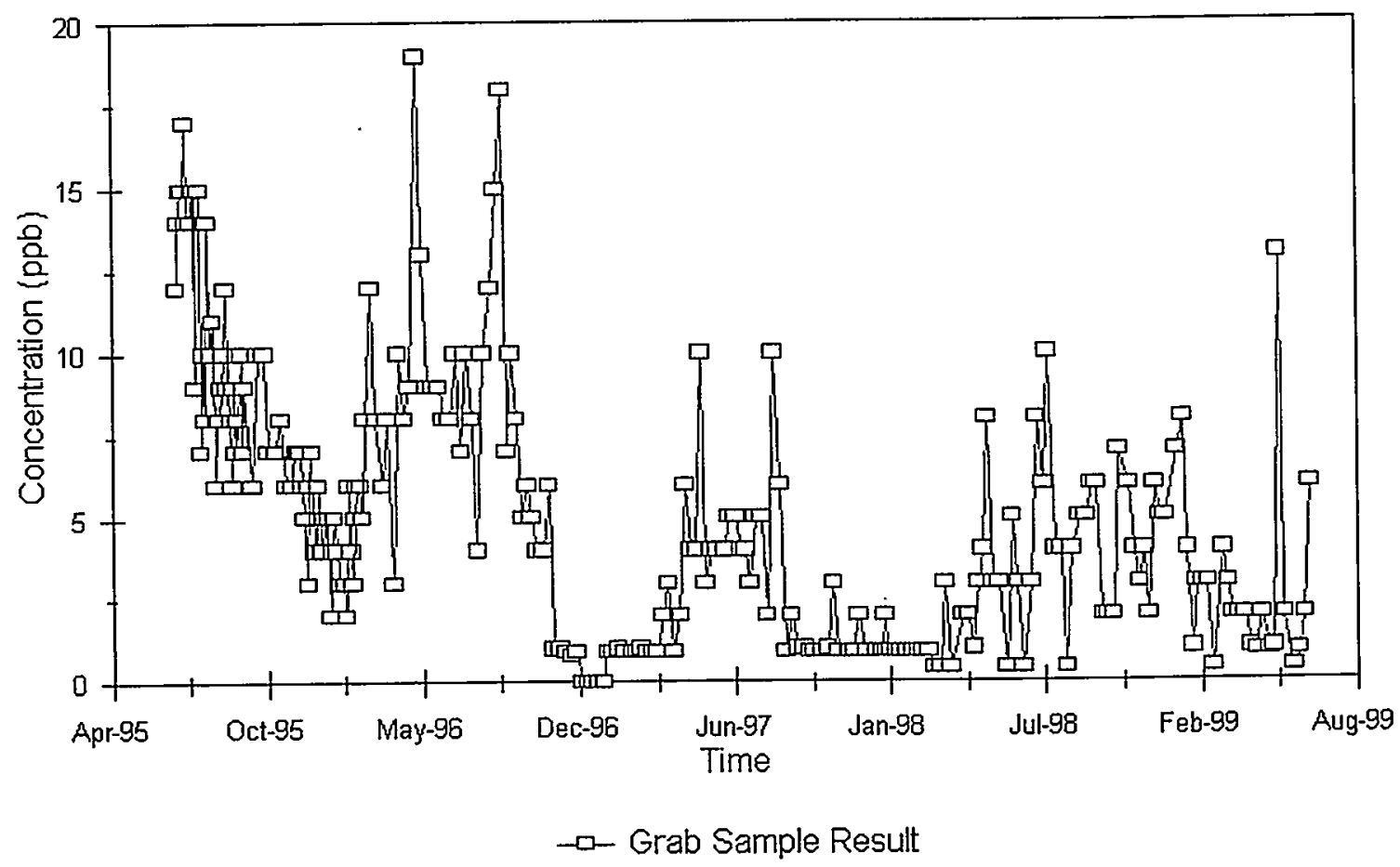

Figure B-4. TEDF Effluent Variability - Chloroform

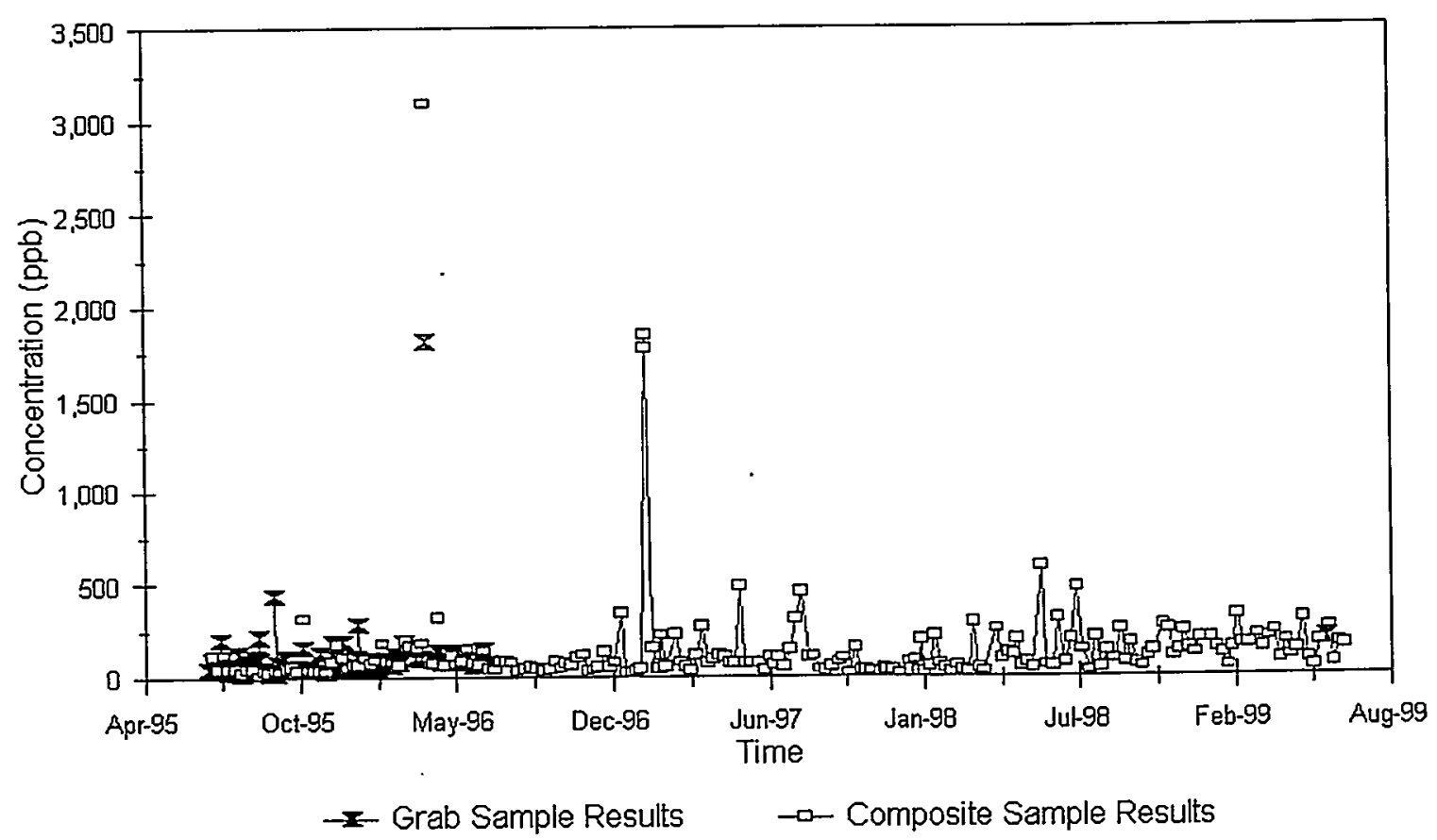

Figure B-5. TEDF Effluent Variability - Iron 


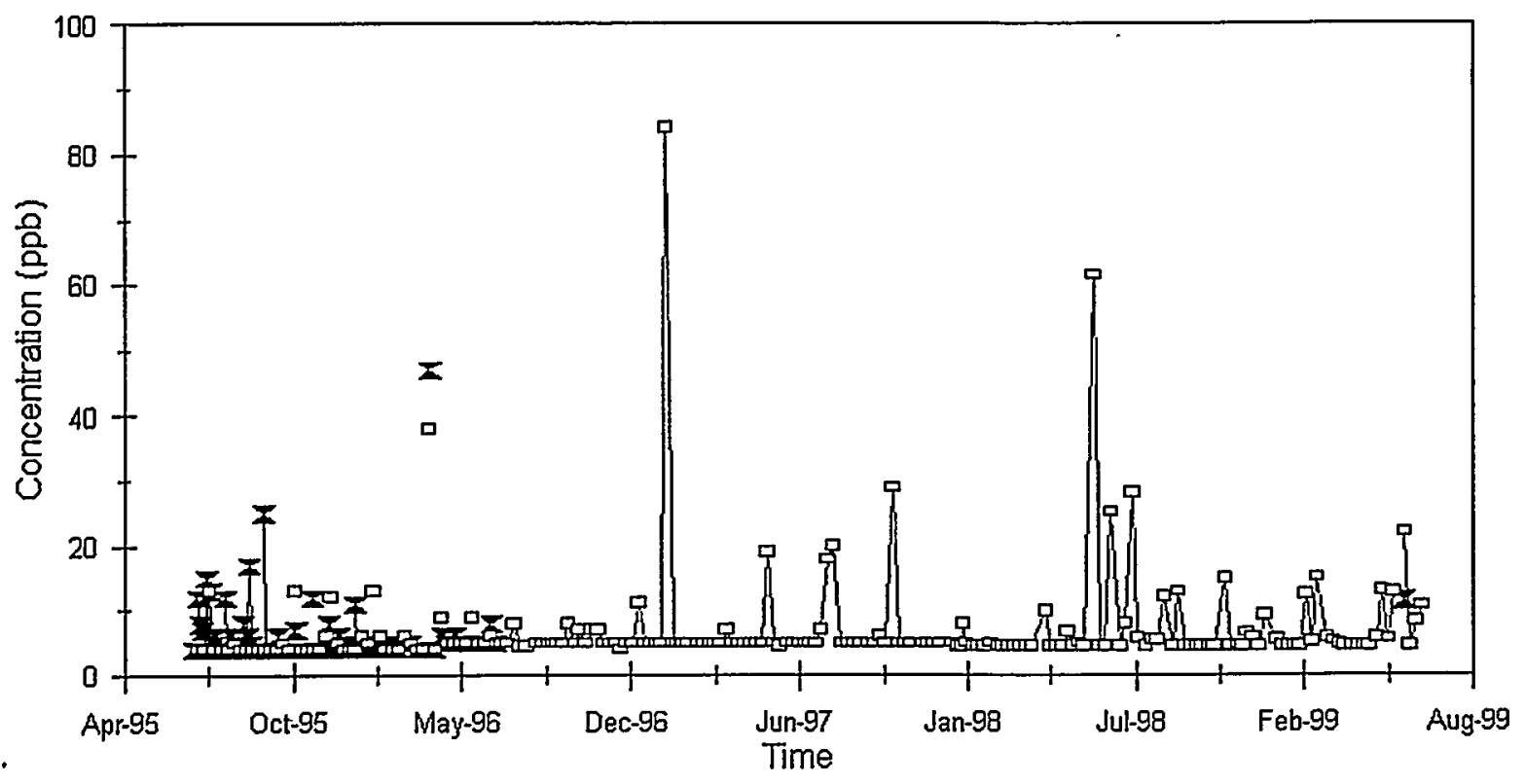

$\rightarrow$ - Grab Sample Result $\quad$ - $\quad$ - Composite Sample Result

Figure B-6. TEDF Effluent Variability - Manganese

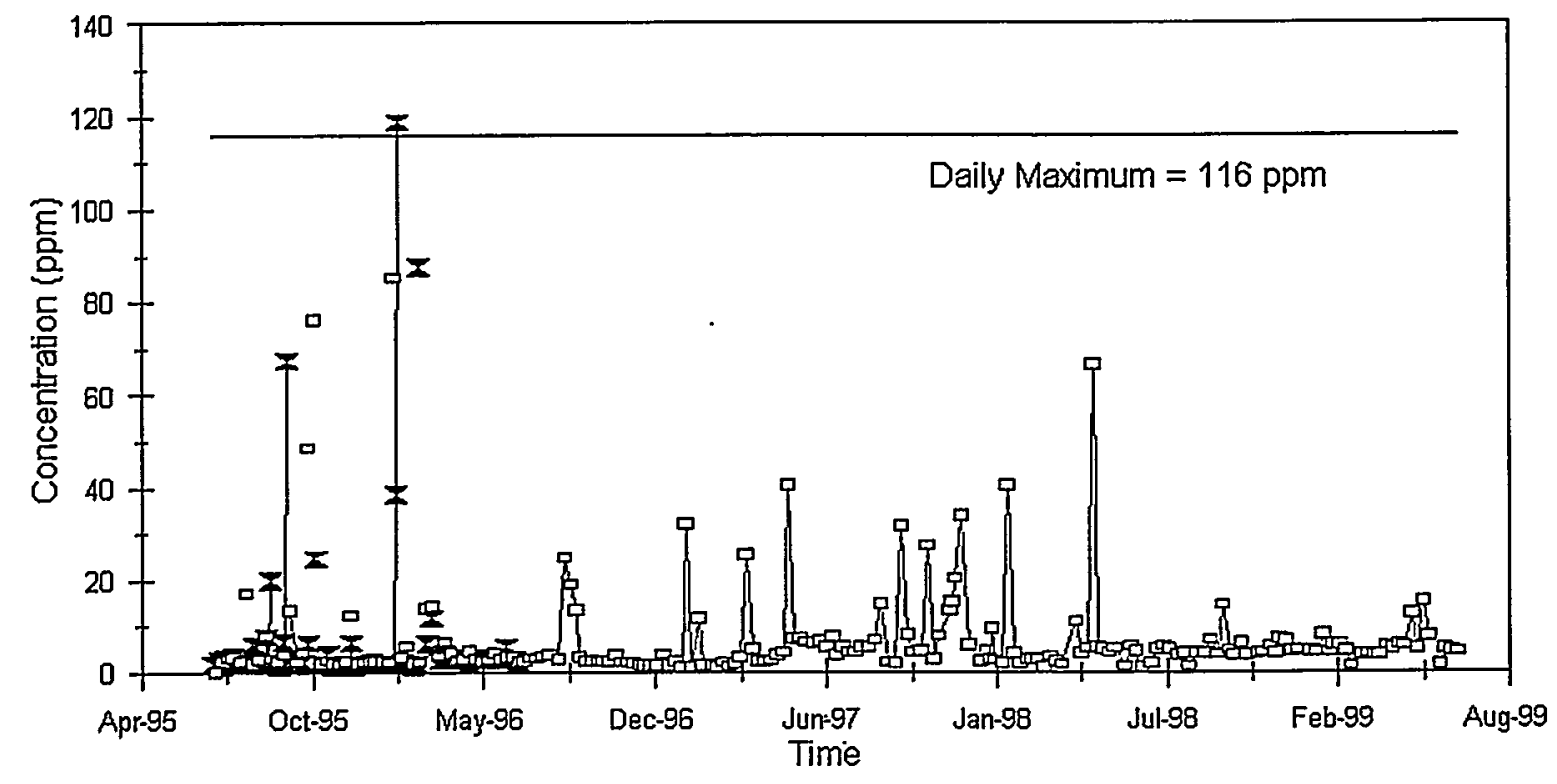

$\rightarrow-$ Grab Sample Results $\quad \rightarrow$ Composite Sample Results $\quad \longrightarrow$ Enforcement Limit in Effluent

Figure B-7. TEDF Effluent Variability - Chloride 


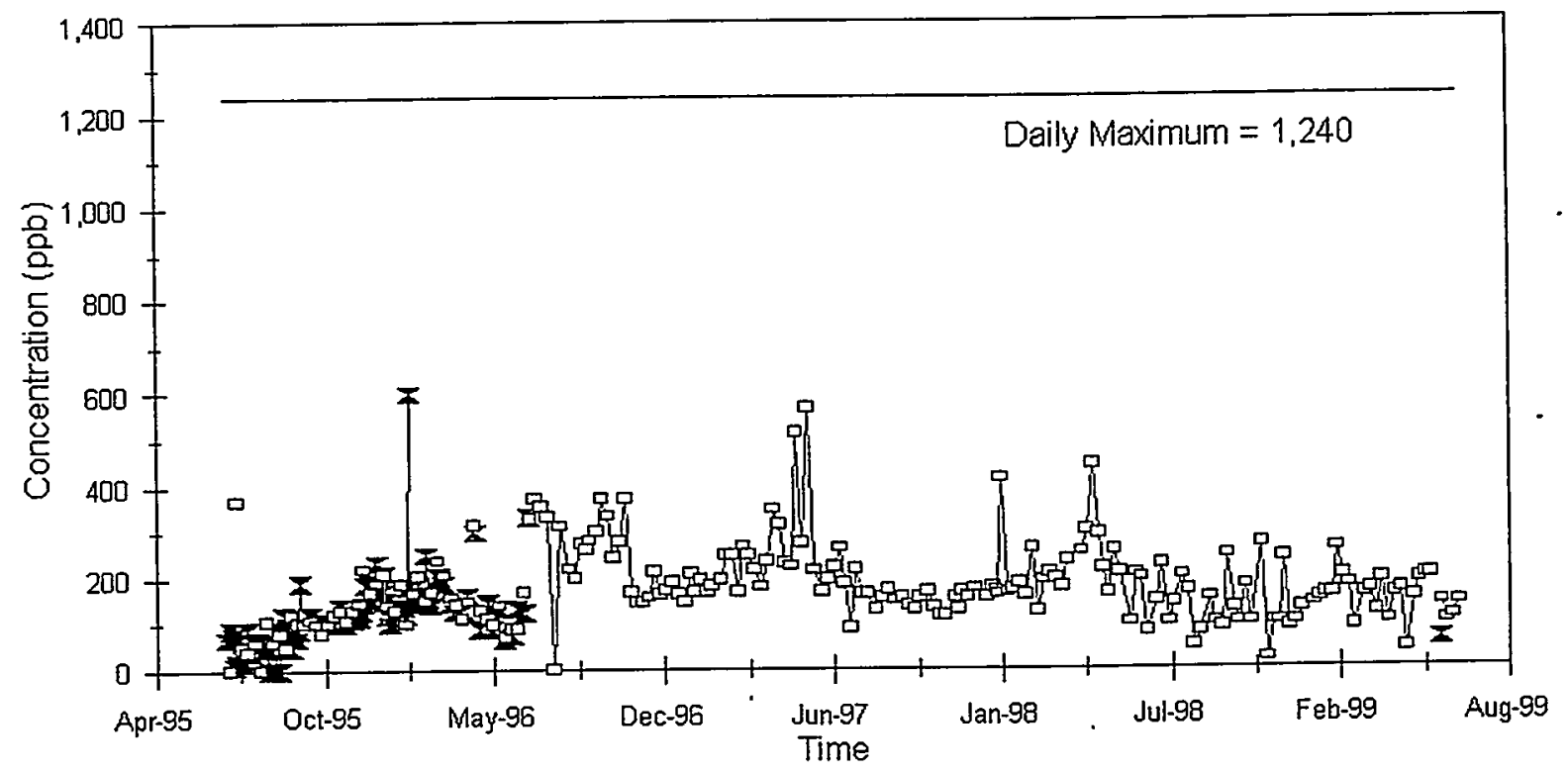

I- Grab Sample Result $\quad \rightarrow$ - Composite Sample Result $\quad \longrightarrow$ Enforcement Limit in Effluent

Figure B-8. TEDF Effluent Variability - Nitrate (as N)

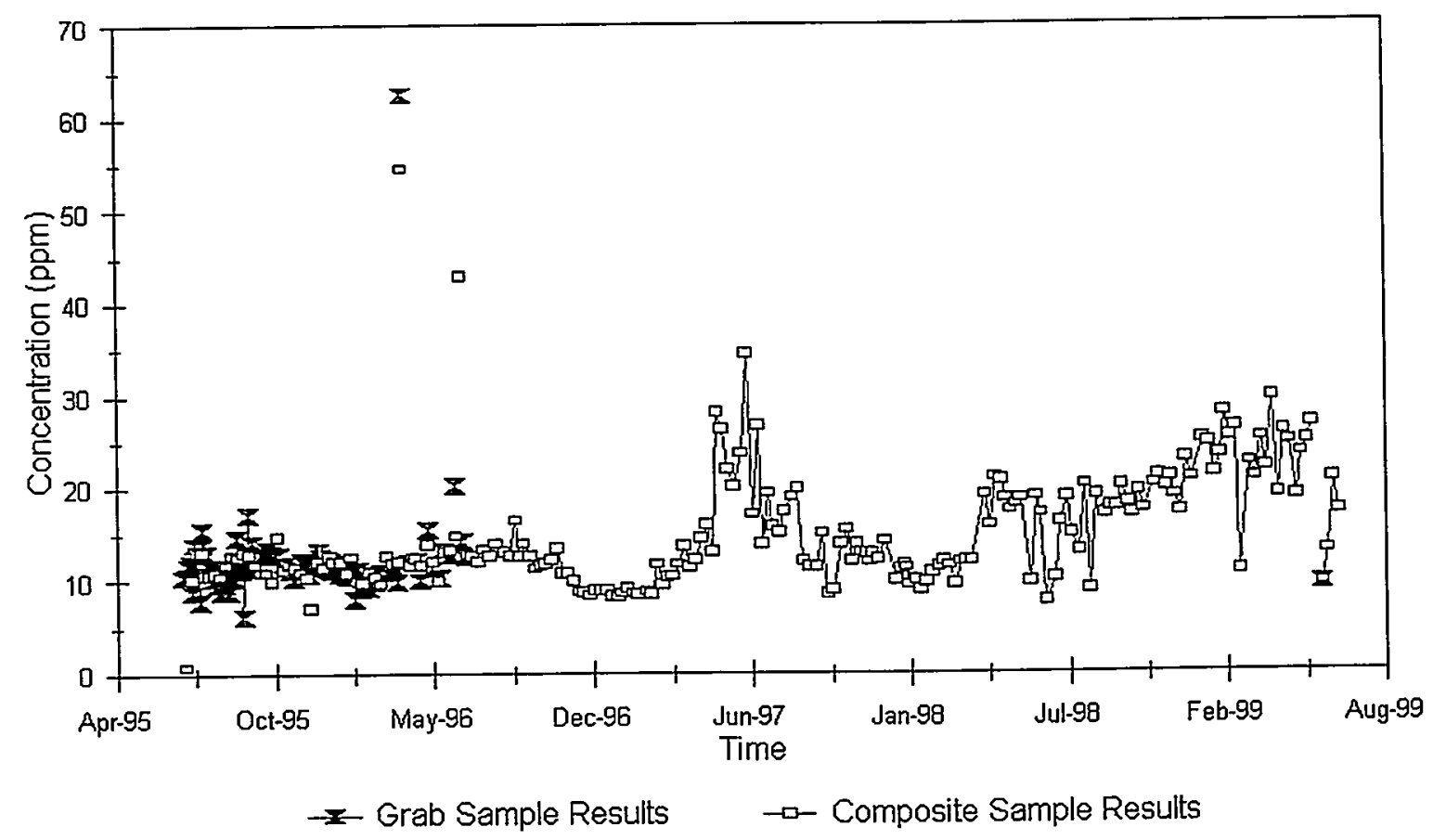

Figure B-9. TEDF Effluent Variability - Sulfate

B. 12 


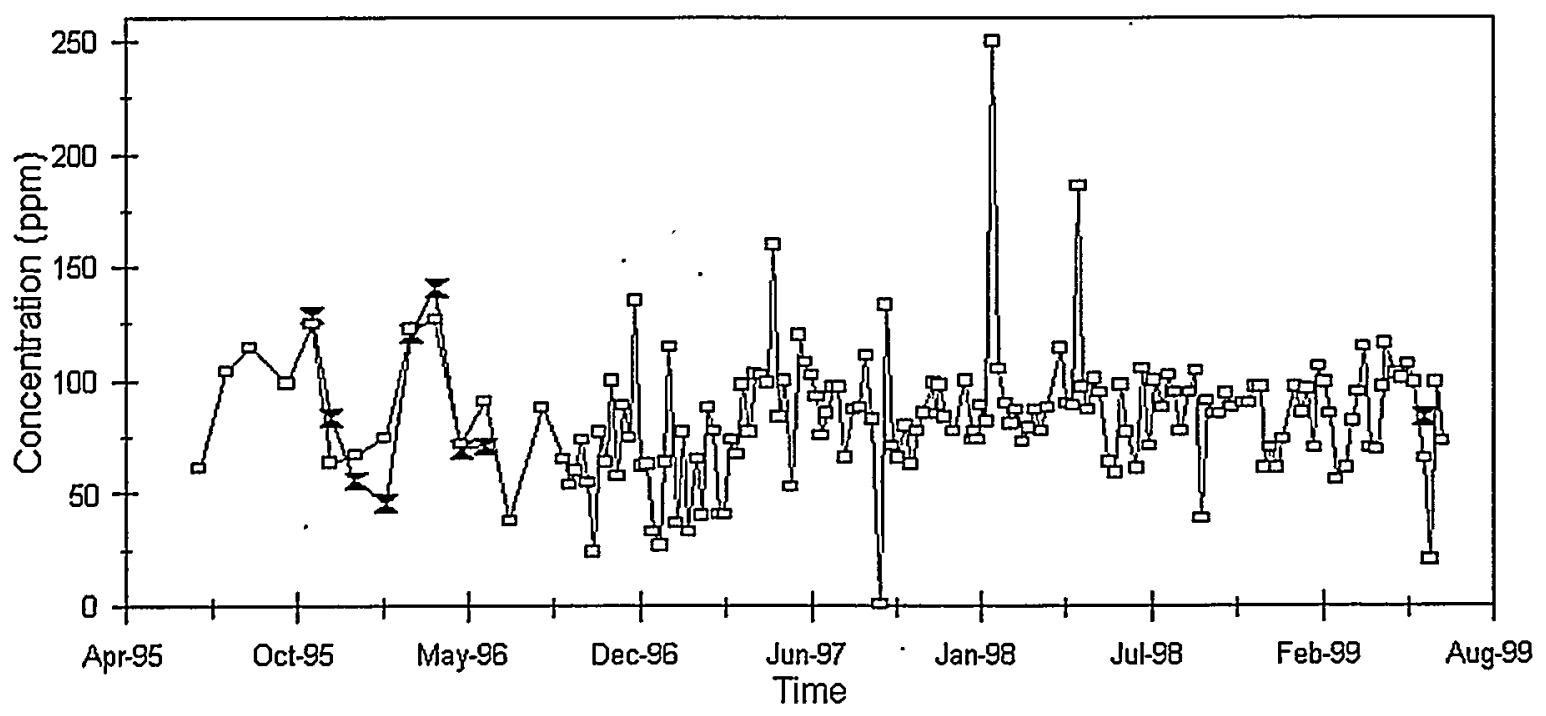

$\rightarrow$ - Grab Sample Results $\quad \therefore$ - Composite Sample Results

Figure B-10. TEDF Effluent Variability - Total Dissolved Solids

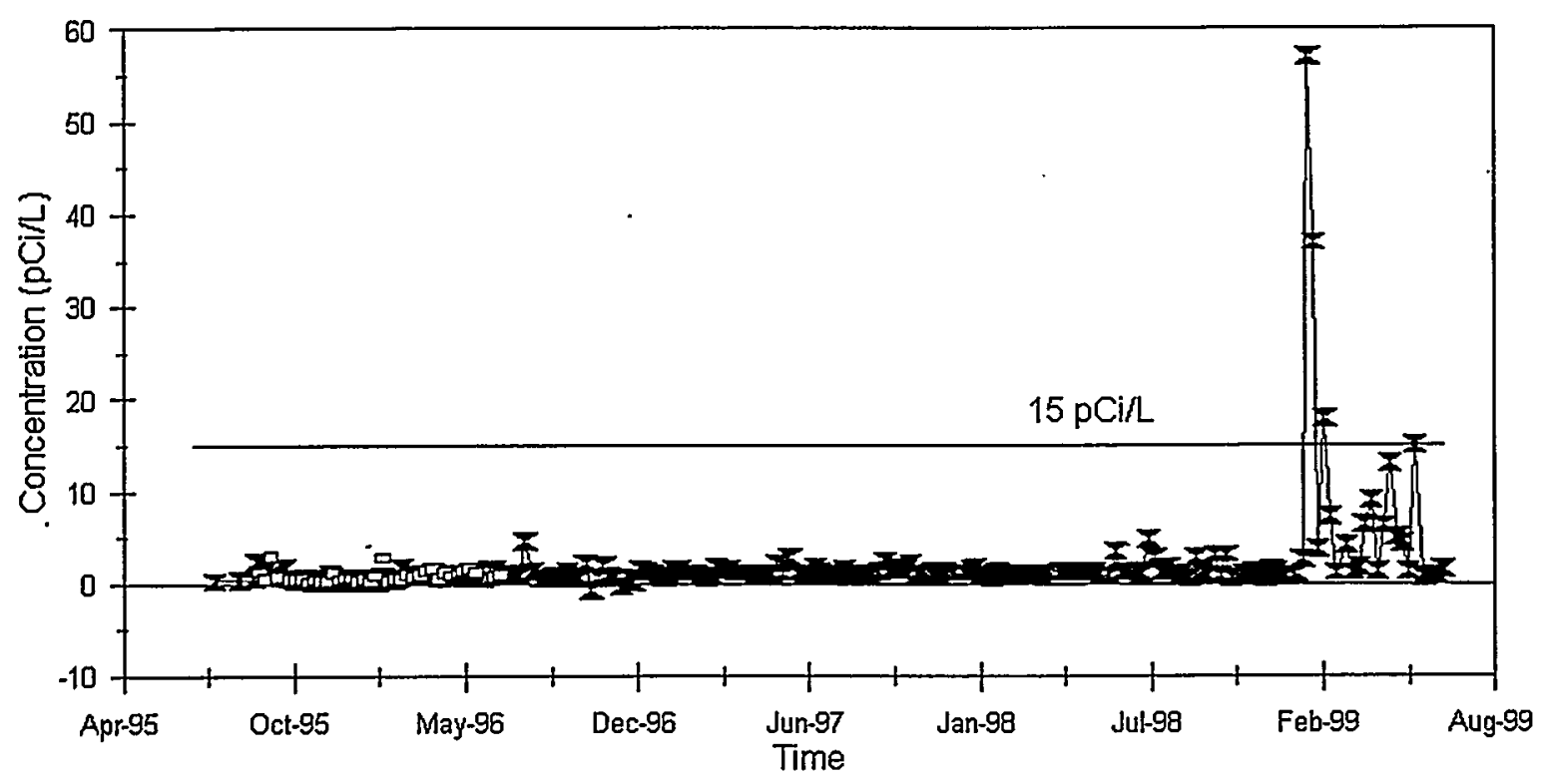

-I- Grab Sample Results $\quad$ - $\quad$ - Composite Sample Results — Drinking Water Standard

Figure B-11. TEDF Effluent Variability - Gross Alpha 


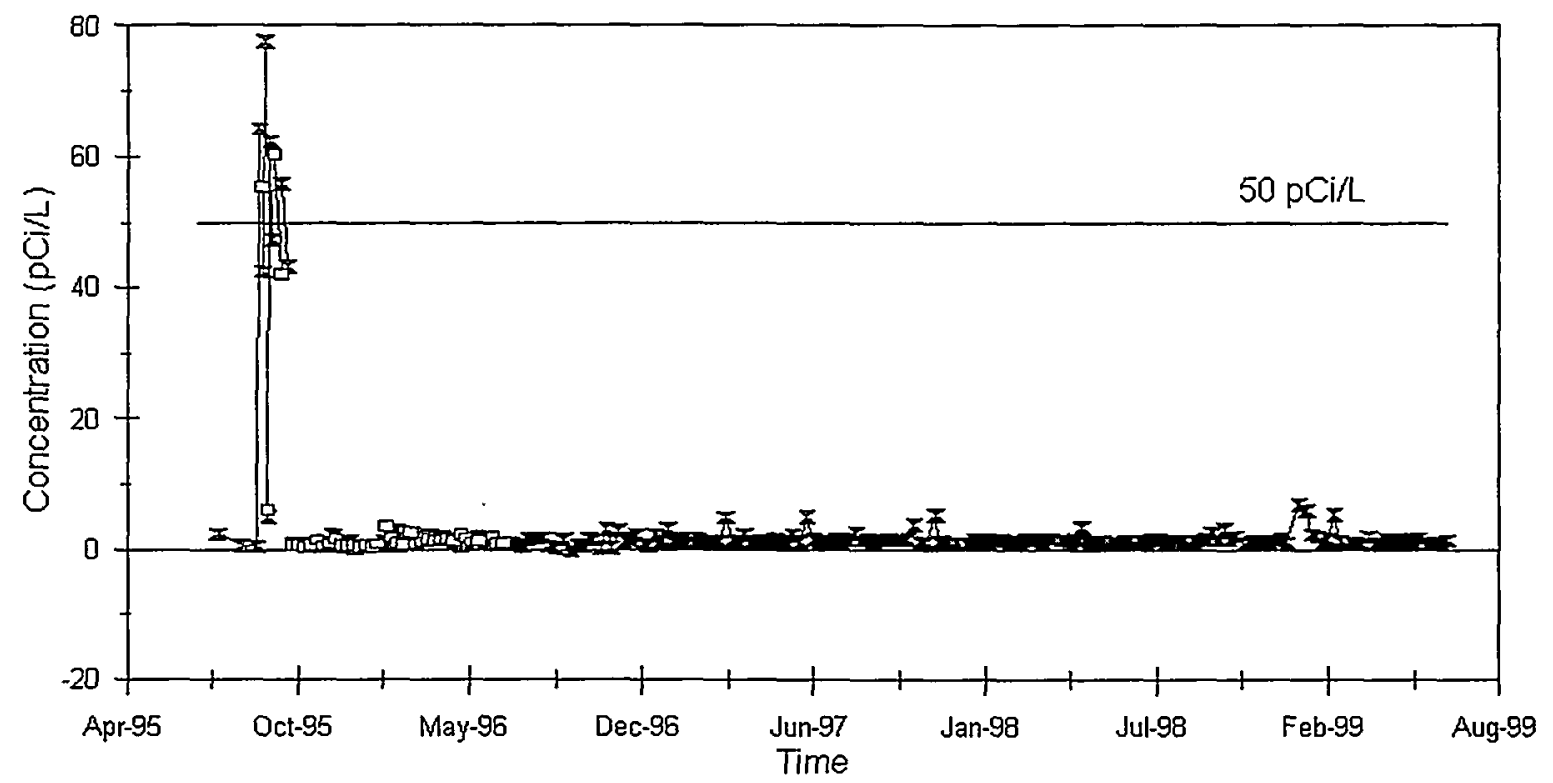

$\rightarrow$ Grab Sample Results $\quad \rightarrow-$ Composite Sample Results $\longrightarrow$ Drinking Water Standard

Figure B-12. TEDF Effluent Variability - Gross Beta 


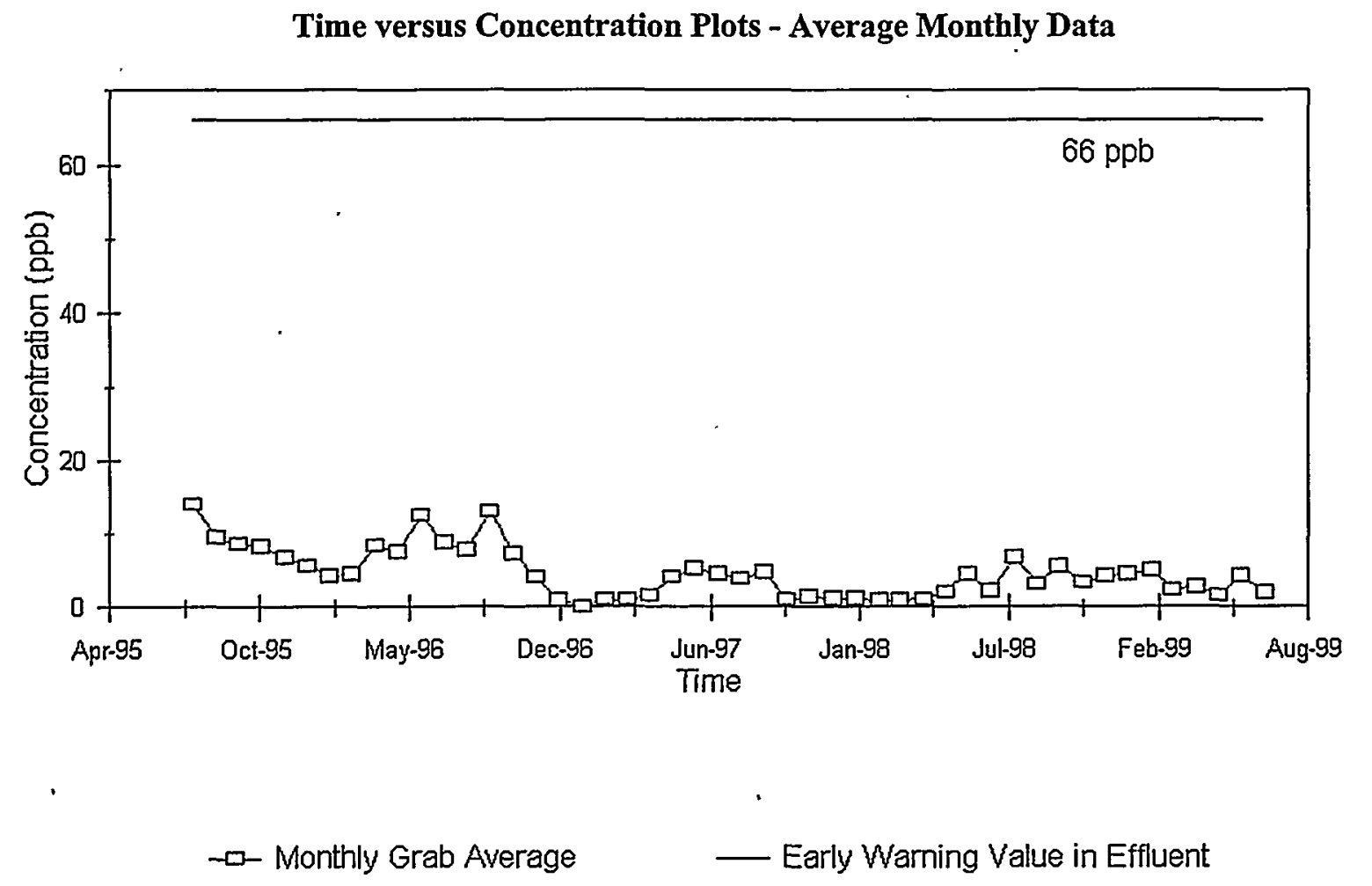

Figure B-13. TEDF Effluent Monitoring Result - Chloroform Monthly Averages

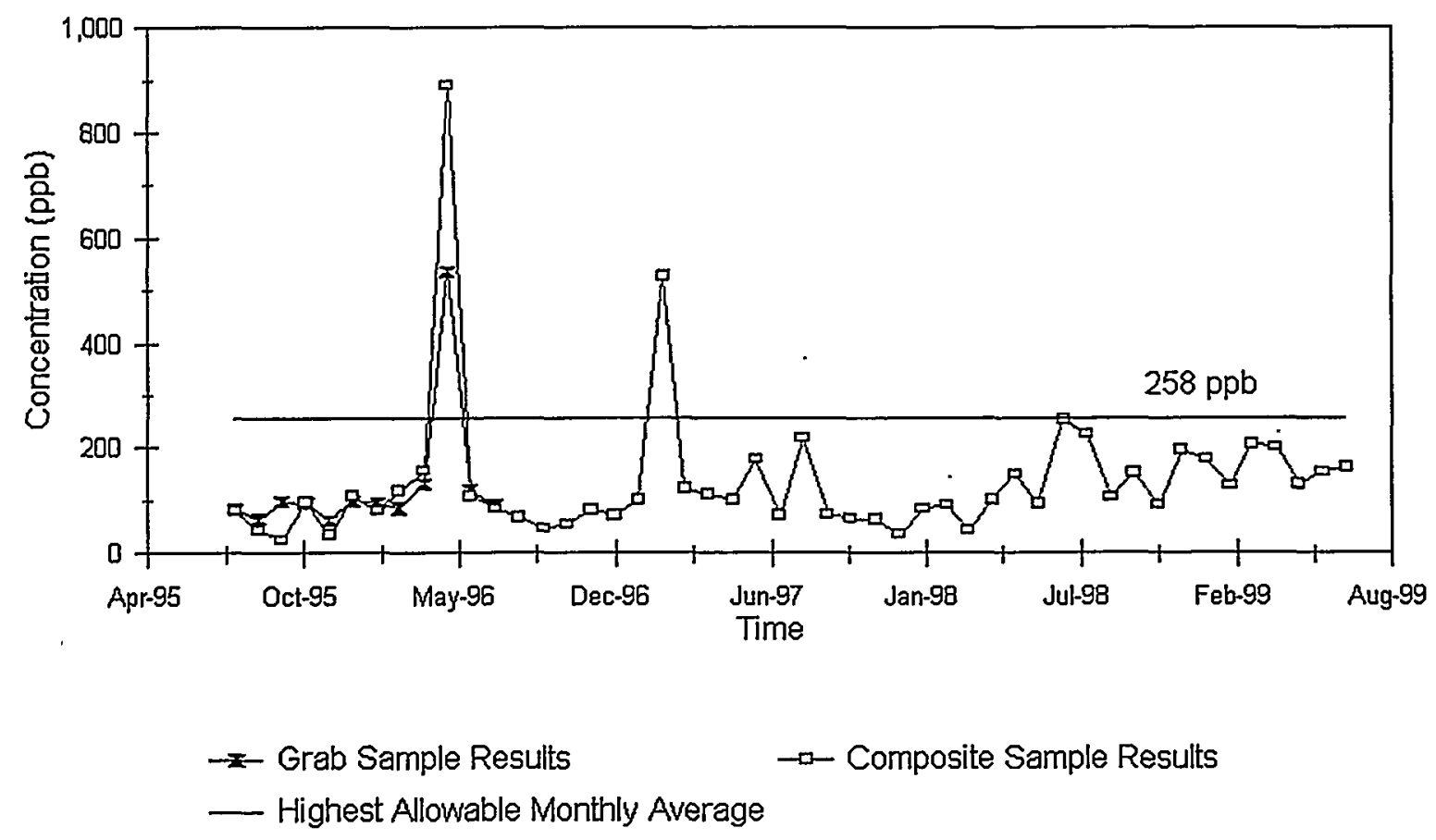

Figure B-14. TEDF Effluent Monitoring Result - Iron Monthly Averages

B.15 


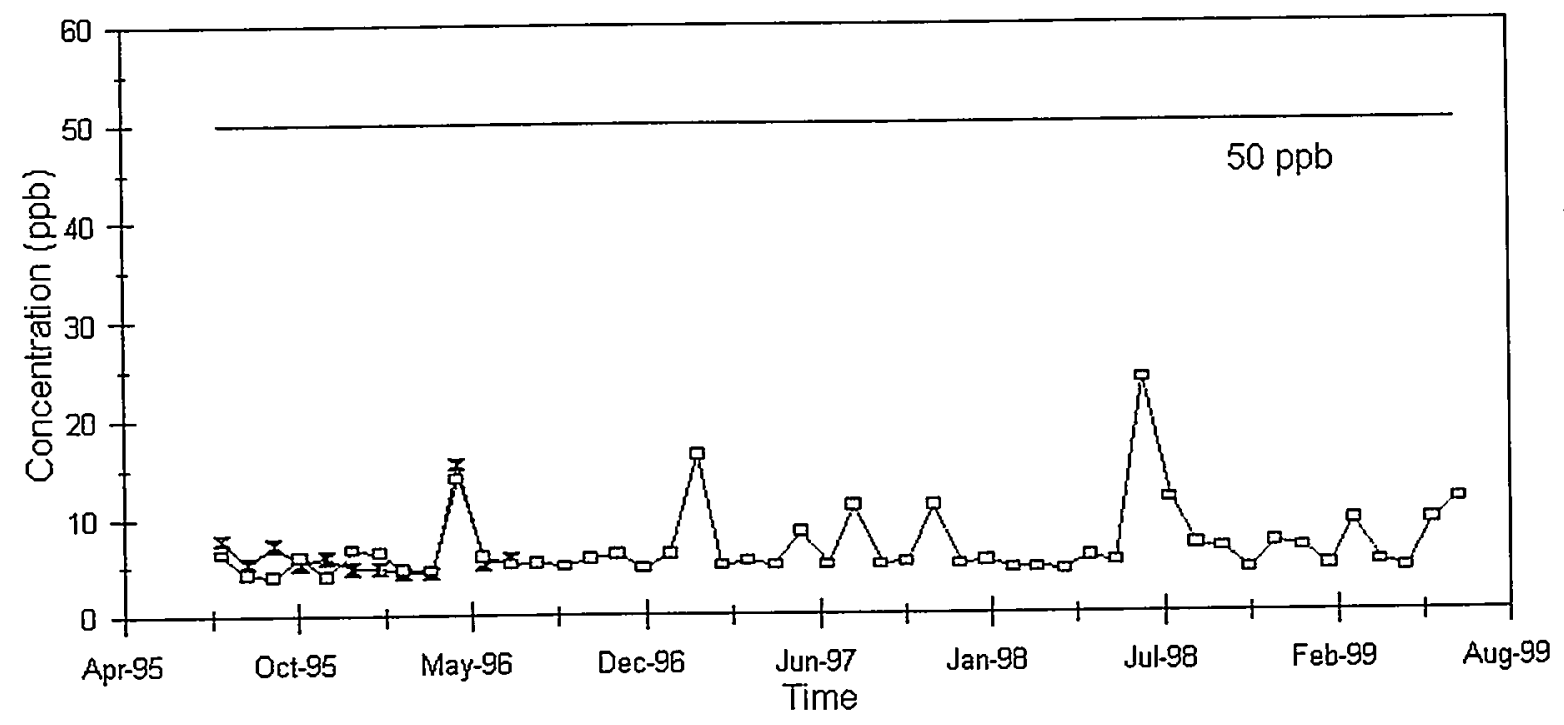

$\rightarrow$ - Grab Sample Results $\quad \rightarrow$ Composite Sample Results

- Highest Allowable Monthly Average

Figure B-15. TEDF Effluent Monitoring Result - Manganese Monthly Averages

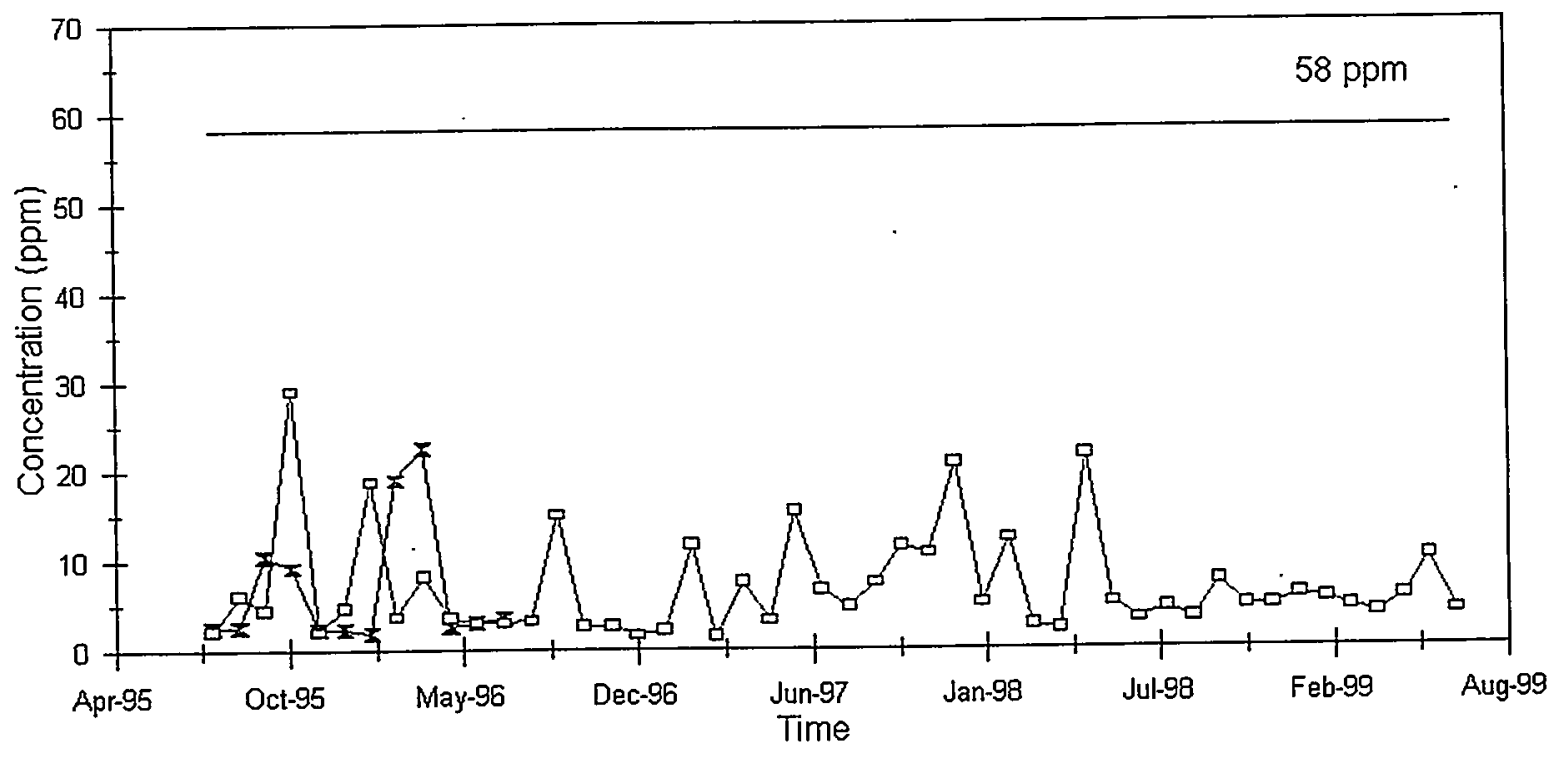

$\rightarrow$ Grab Sample Results $\quad \rightarrow$ Composite Sample Results

_ Highest Allowable Monthly Average

Figure B-16. TEDF Effluent Monitoring Result - Chloride Monthly Averages 


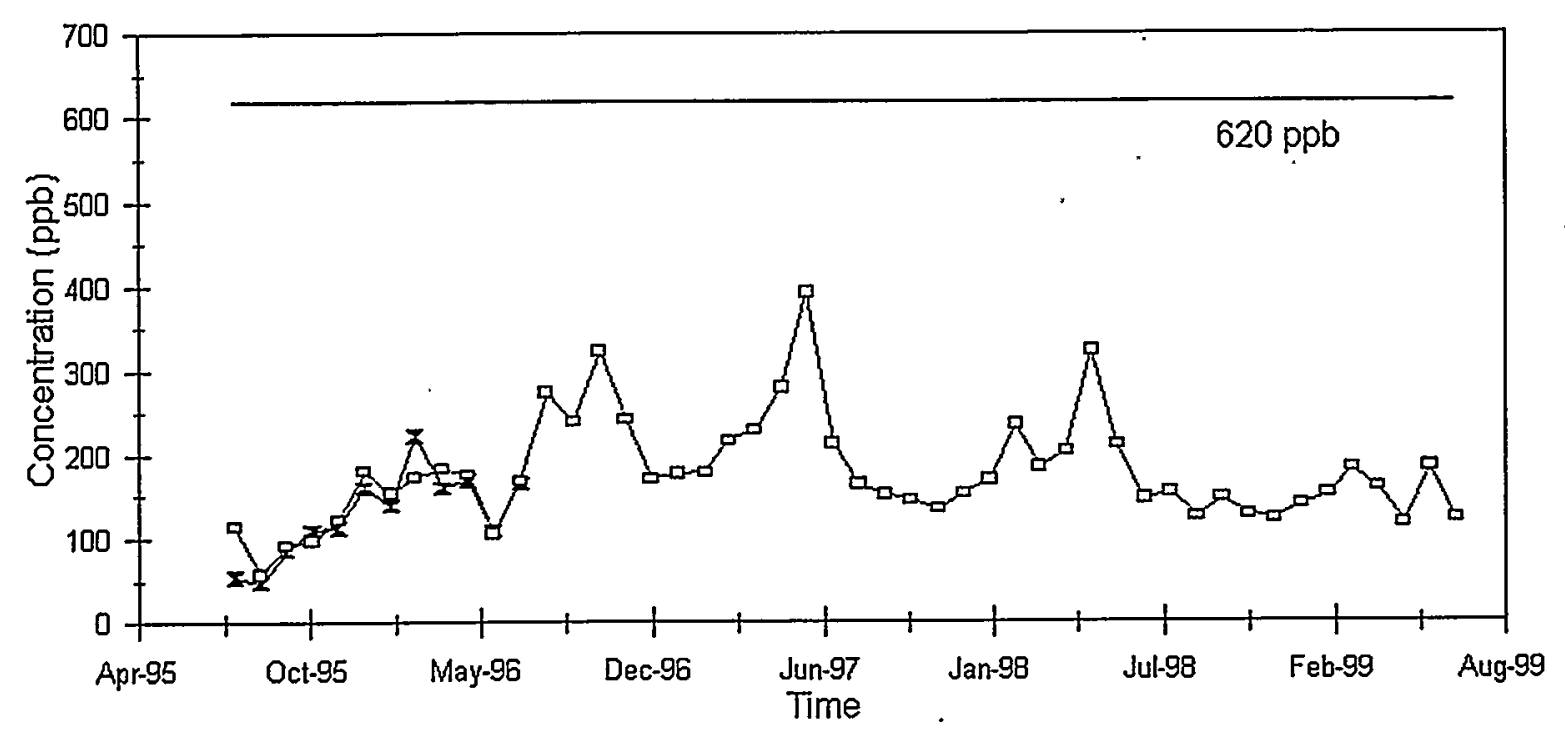

$\rightarrow-$ Grab Sample Results $\quad \rightarrow-$ Composite Sample Results

— Highest Allowable Monthly Average ' .

Figure B-17. TEDF Effluent Monitoring Result - Nitrate (as N) Monthly Averagẹ

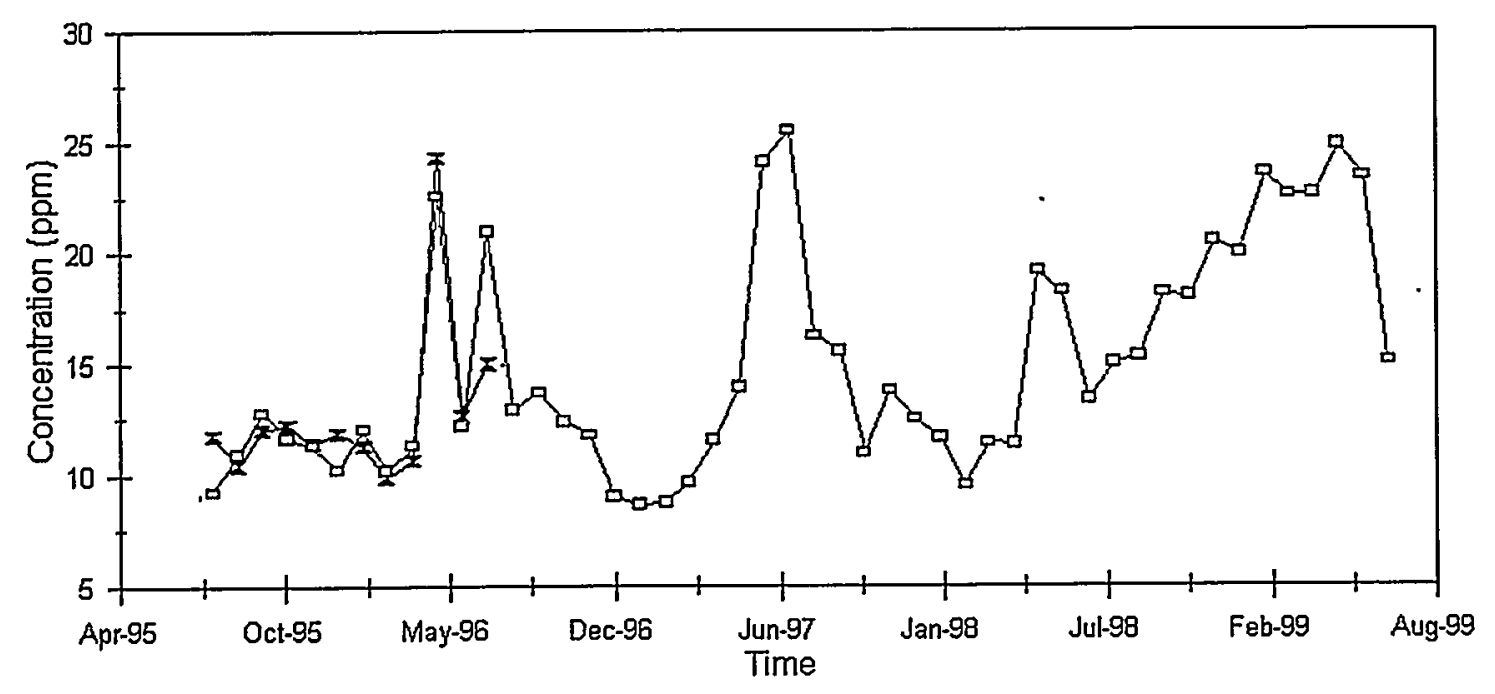

$\rightarrow$ - Grab Sample Results $\quad \rightarrow$ Composite Sample Results

Figure B-18. TEDF Effluent Monitoring Result - Sulfate Monthly Averages

B. 17 


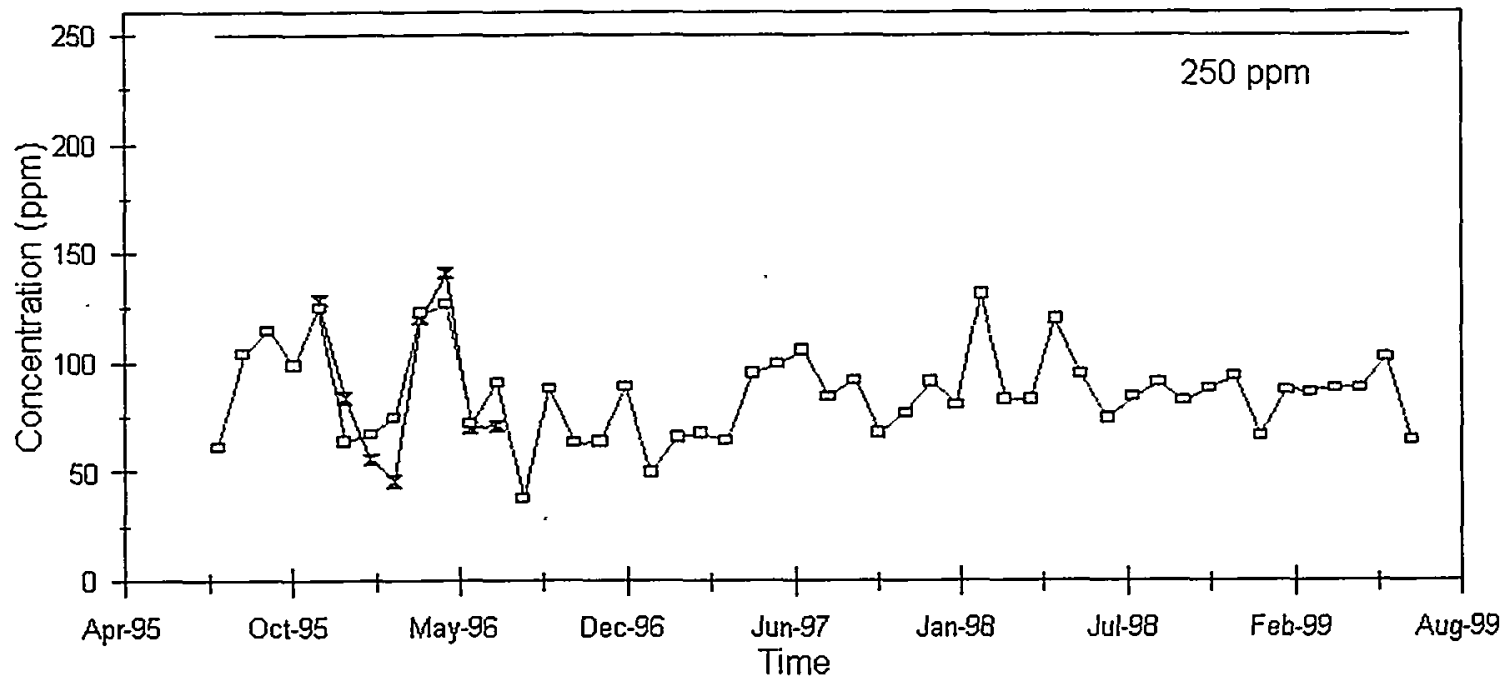

$\rightarrow$ - Grab Sample Results $\quad \rightarrow \square-$ Composite Sample Results

- Highest Allowable Monthly Average

Figure B-19. TEDF Effluent Monitoring Result - Total Dissolved Solids (TDS) Monthly Averages

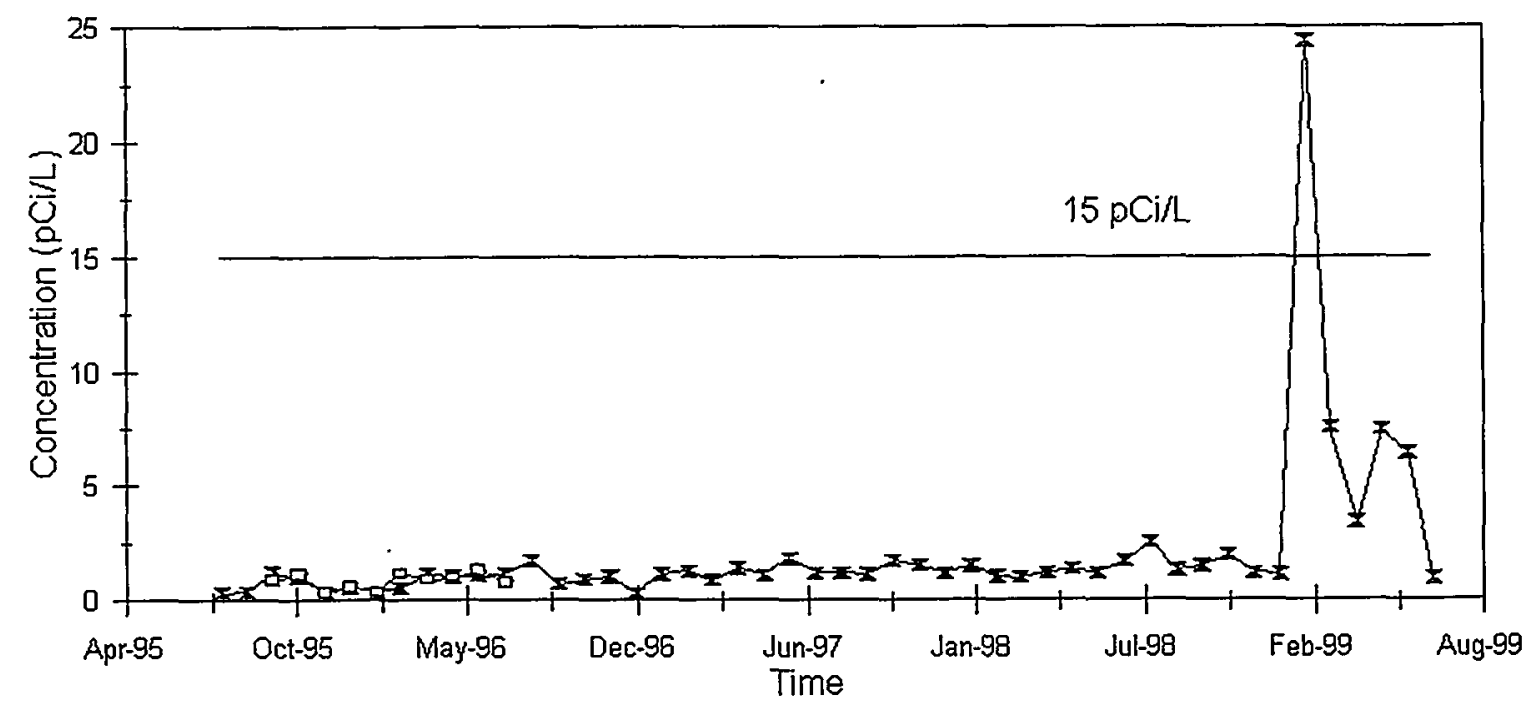

-x-Grab Sample Results _ - Composite Sample Results — Drinking Water Standard

Figure B-20. TEDF Effluent Monitoring Result - Gross Alpha Monthly Averages 


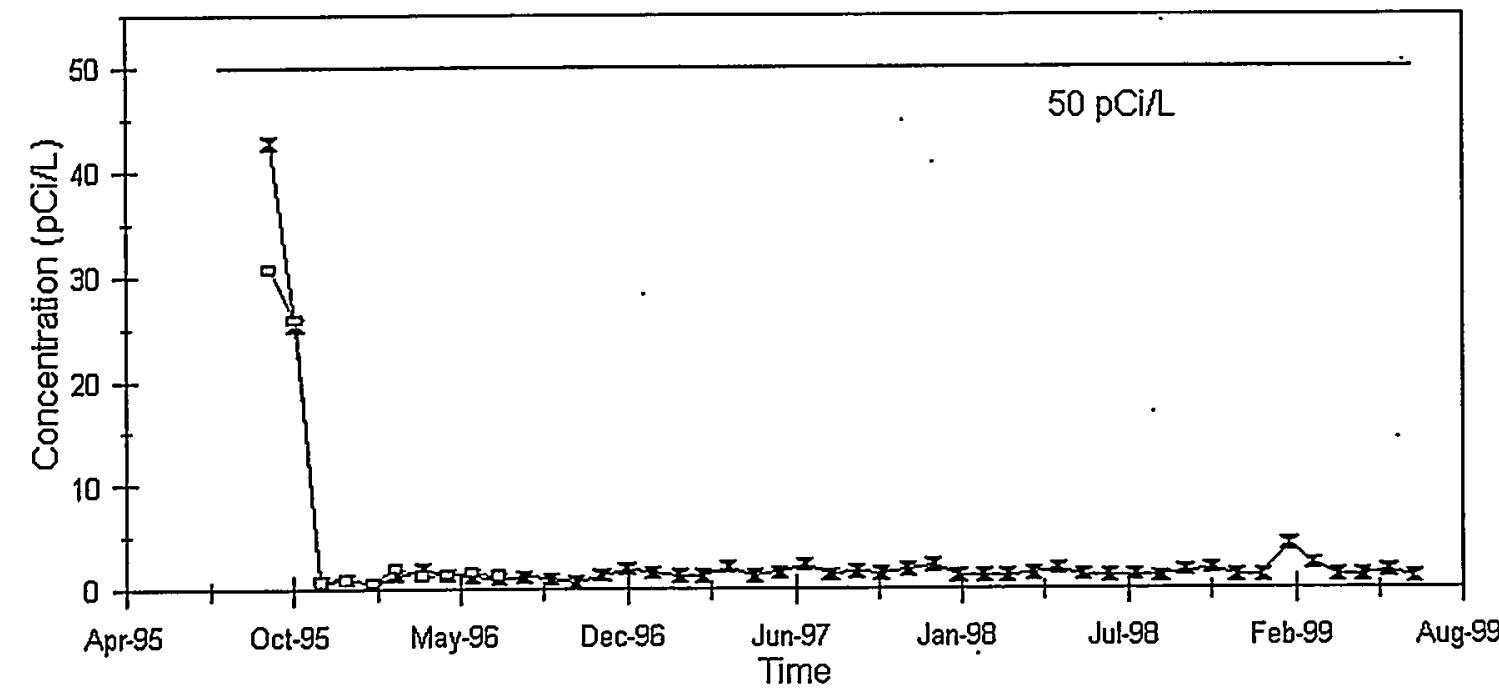

$\rightarrow-$ Grab Sample Results $\quad \rightarrow$ Composite Sample Results - - Drinking Water Standard

Figure B-21. TEDF Effluent Monitoring Result - Gross Beta Monthly Averages

B. 19 
Multiple Box and Whiskers Plots - Seasonal Effects

Multiple Box-and-Whisker Plot

Chloroform Grab Samples (7/95 - 6/99)

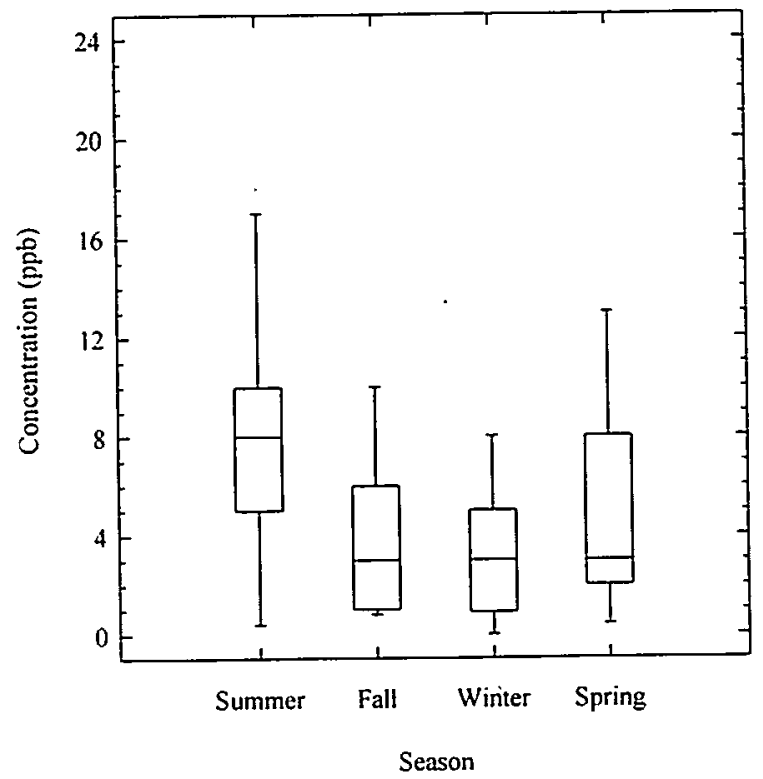

Figure B-22. Chloroform Grab Sample Results Shown by Season

Multiple Box-and-Whisker Plot

Iron Composite Samples (7/95 - 6/99)

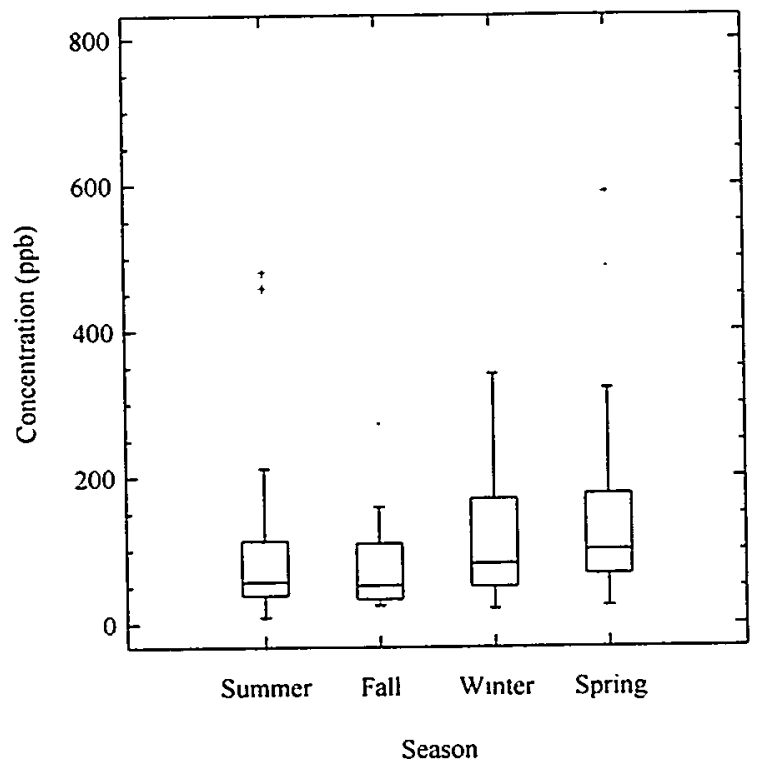

Excursions (4/7/96 \& 1/12/97) Evcluded

Figure B-23. Iron Composite Sample Results Shown by Season 


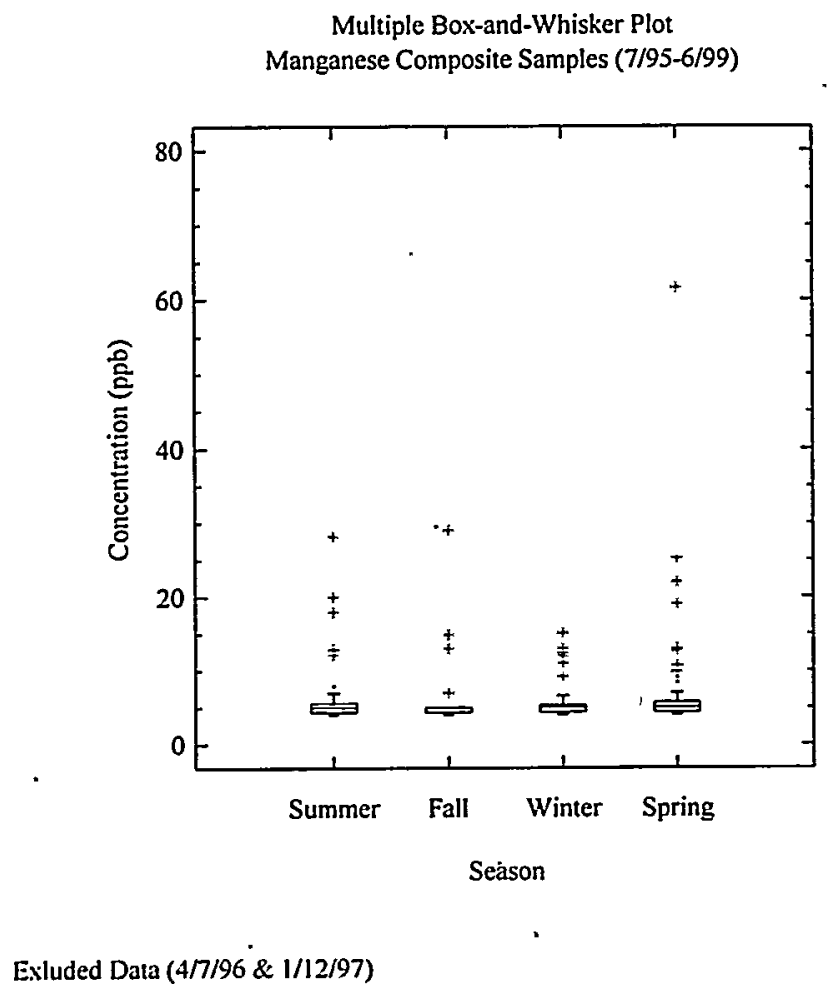

Figure B-24. Manganese Composite Sample Results Shown by Season

Multiple Box-and-Whisker Plot

Chloride Composite Samples (7/95 - 6/99)

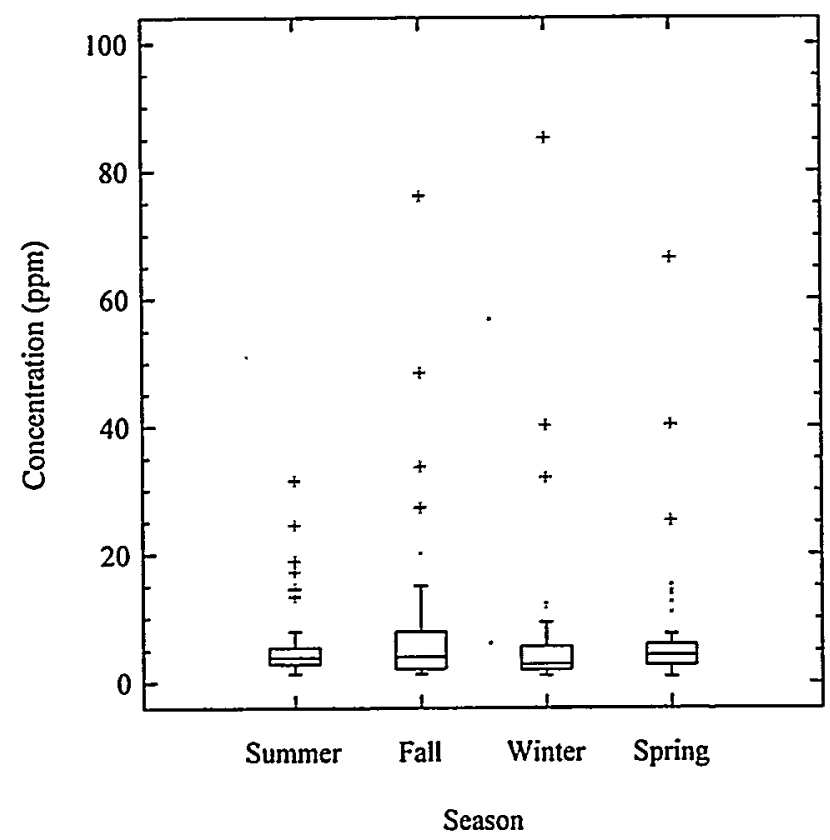

Figure B-25. Chloride Composite Sample Results Shown by Season 


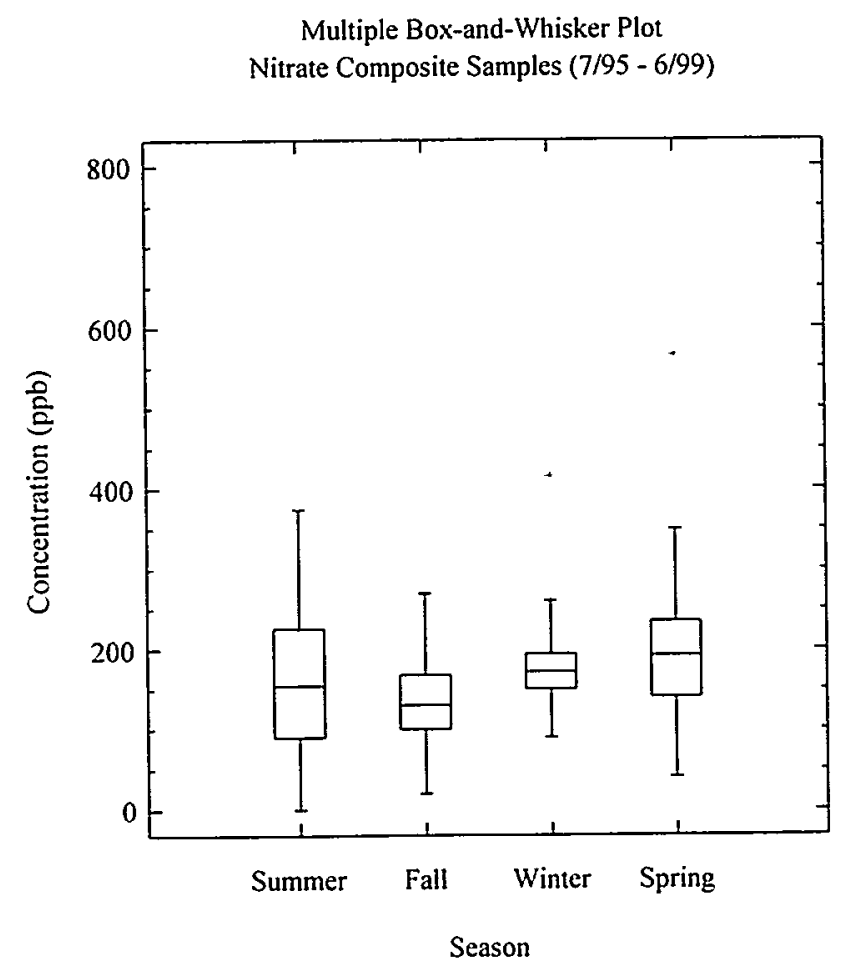

Figure B-26. Nitrate (as N) Composite Sample Results Shown by Season

Muitiple Box-and-Whisker Plot

Sulfate Composite Samples (7/95 - 6/99)

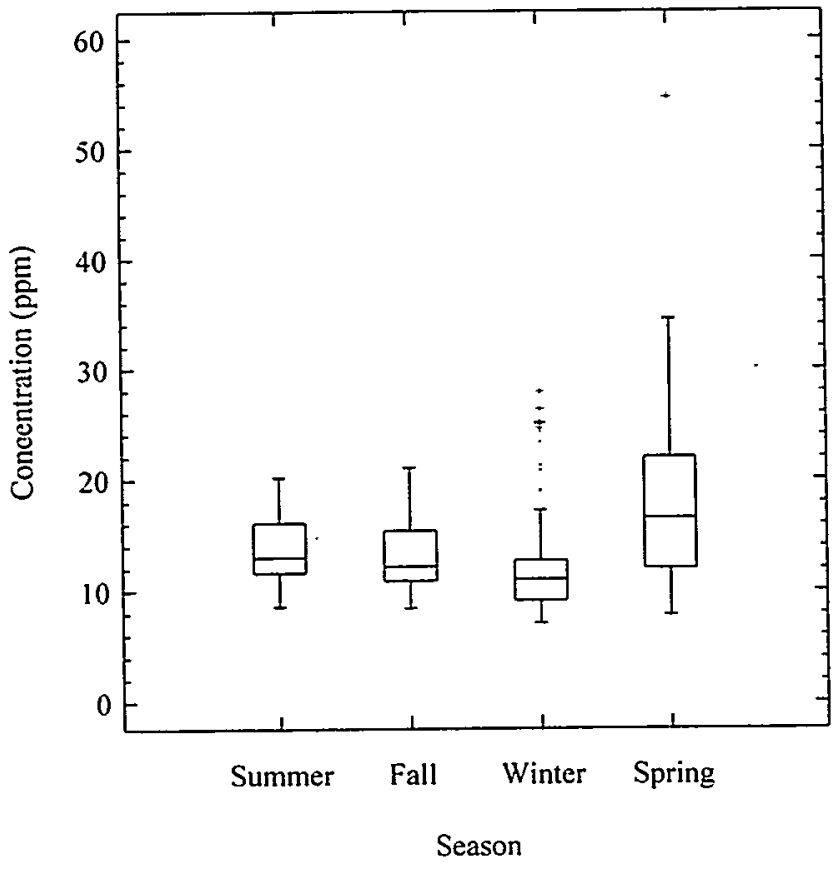

Figure B-27. Sulfate Composite Sample Results Shown by Season 


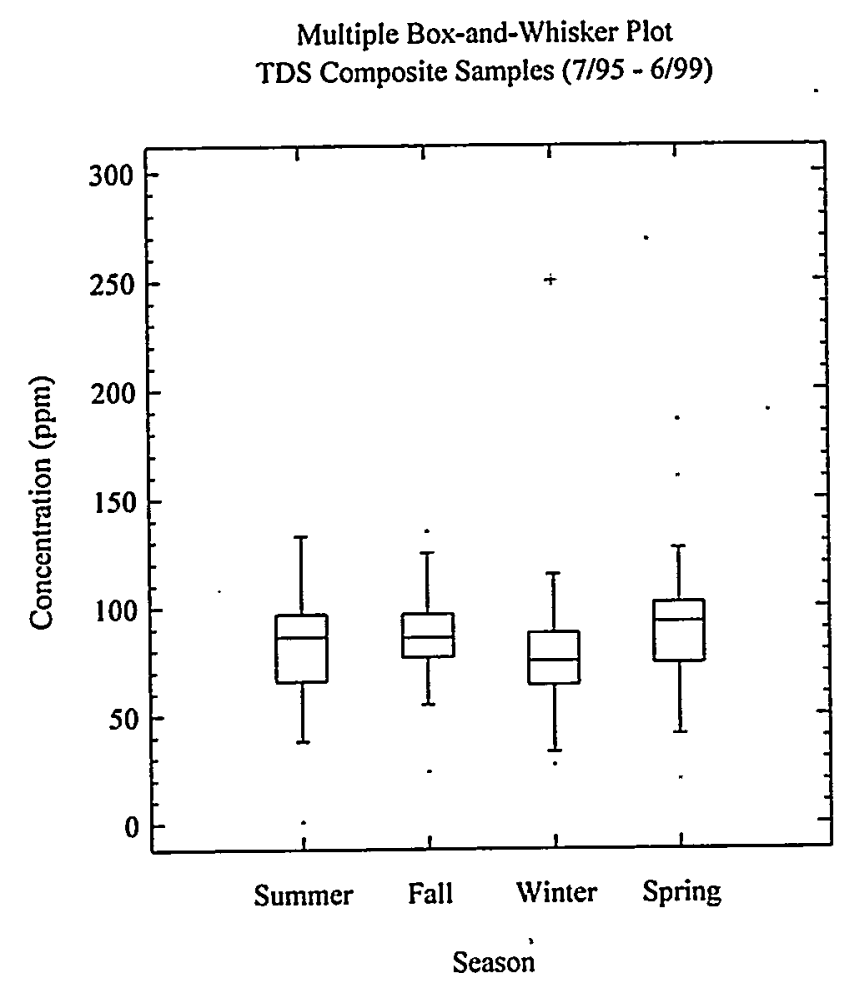

Figure B-28. Total Dissolved Solids Composite Sample Results Shown by Season

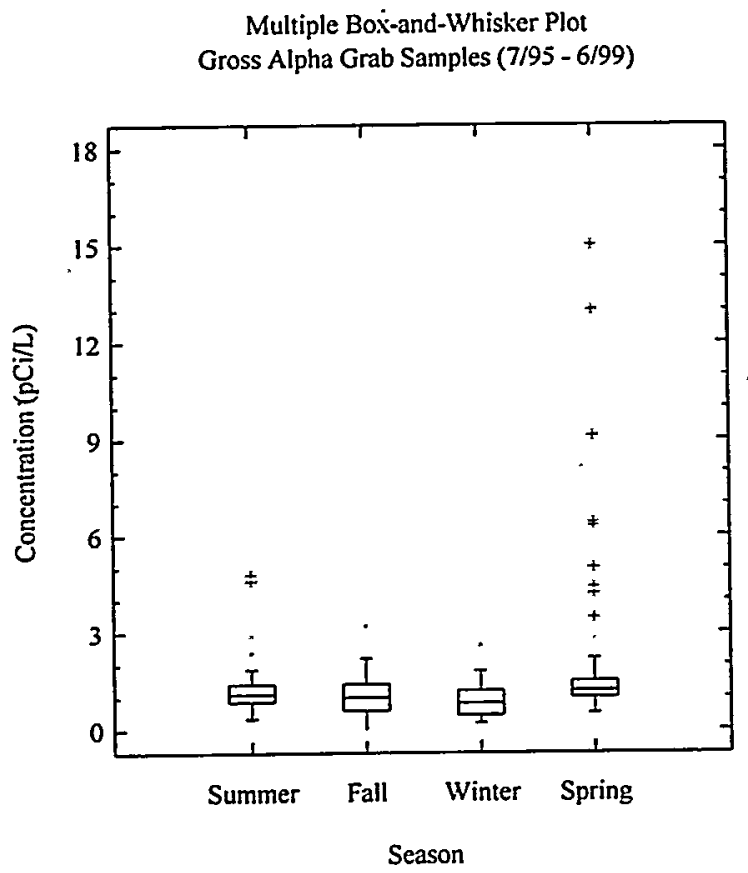

Excluded Data From 1/22/99 to 2/17/99

Figure B-29. Gross Alpha Grab Sample Results Shown by Season 
Multiple Box-and-Whisker Plot

Gross Beta Grab Samples (10/95 - 6/99)

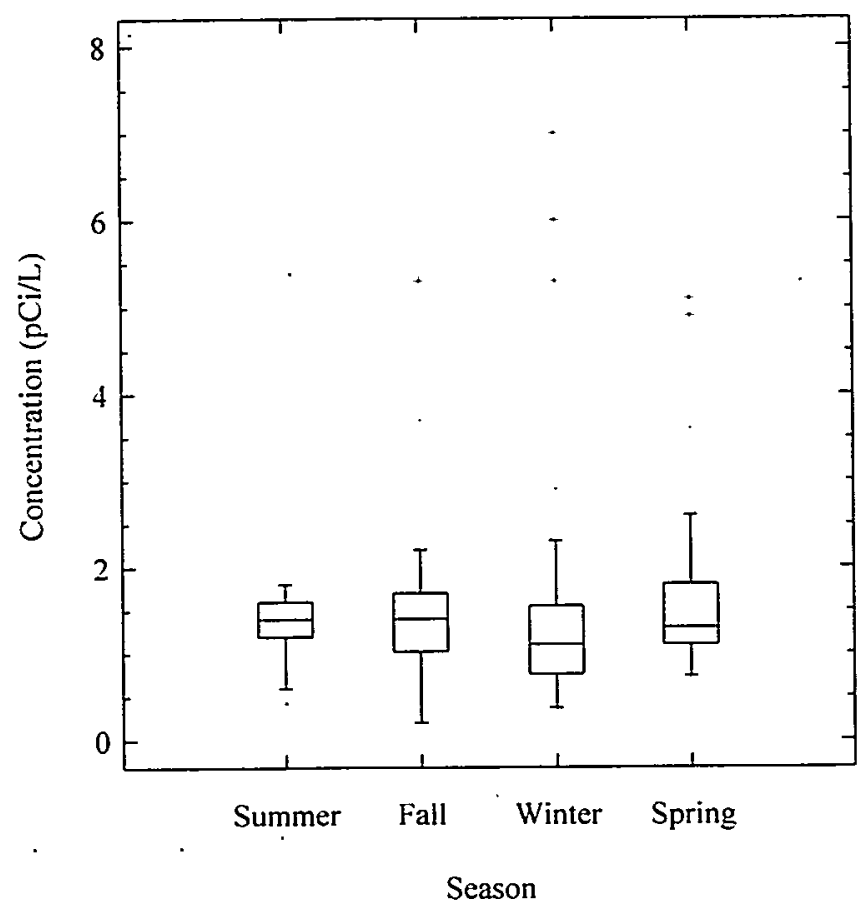

Exclude Data Prior to 10/23/95

Figure B-30. Gross Beta Grab Sample Results Shown by Season 
Multiple Box and Whisker Plots - Sample Type Effects

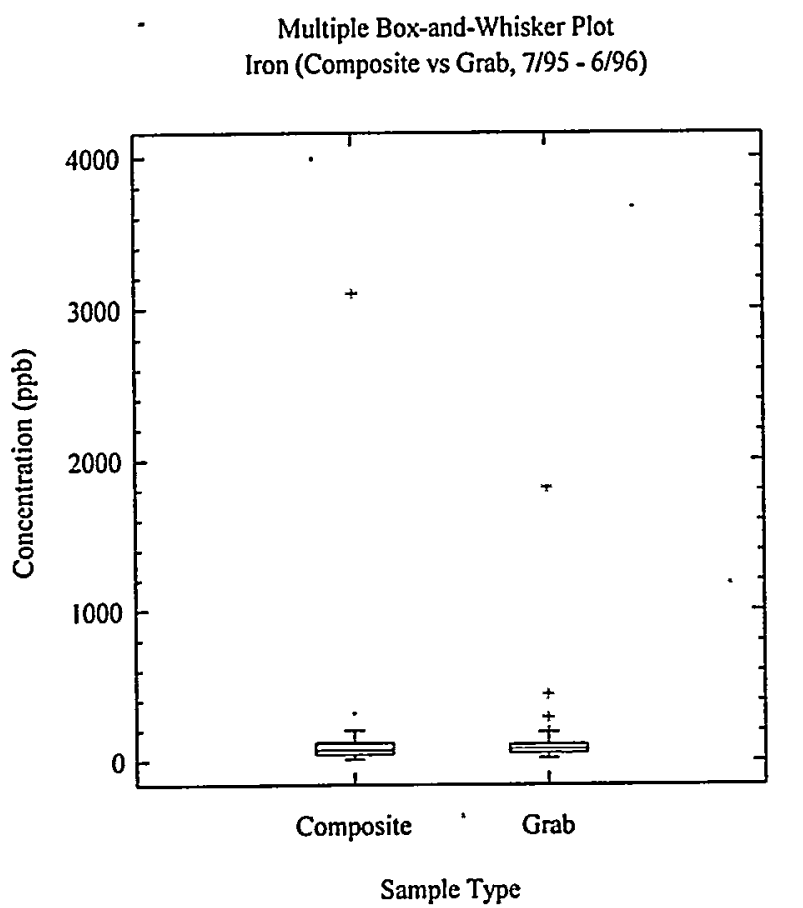

Figure B-31. Multiple Box and Whisker Plot - Iron (Composite versus Grab Sample Results)

Multiple Box-and-Whisker Plot Manganese (Composite vs Grab, 7/95-6/96)

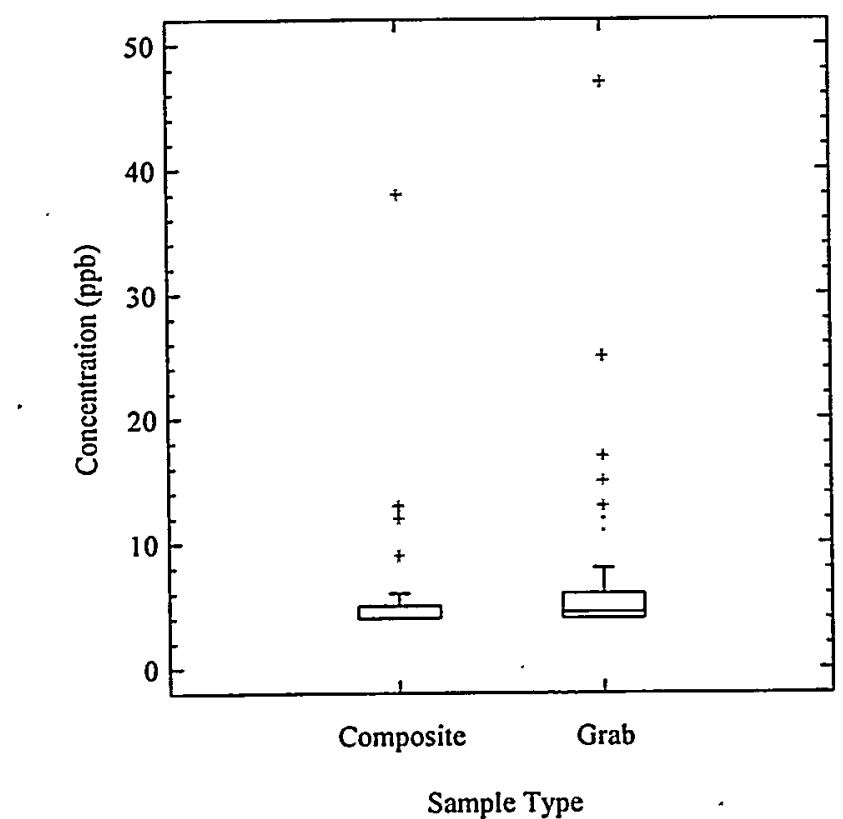

Figure B-32. Multiple Box and Whisker Plots - Manganese (Composite versus Grab Sample Results) 


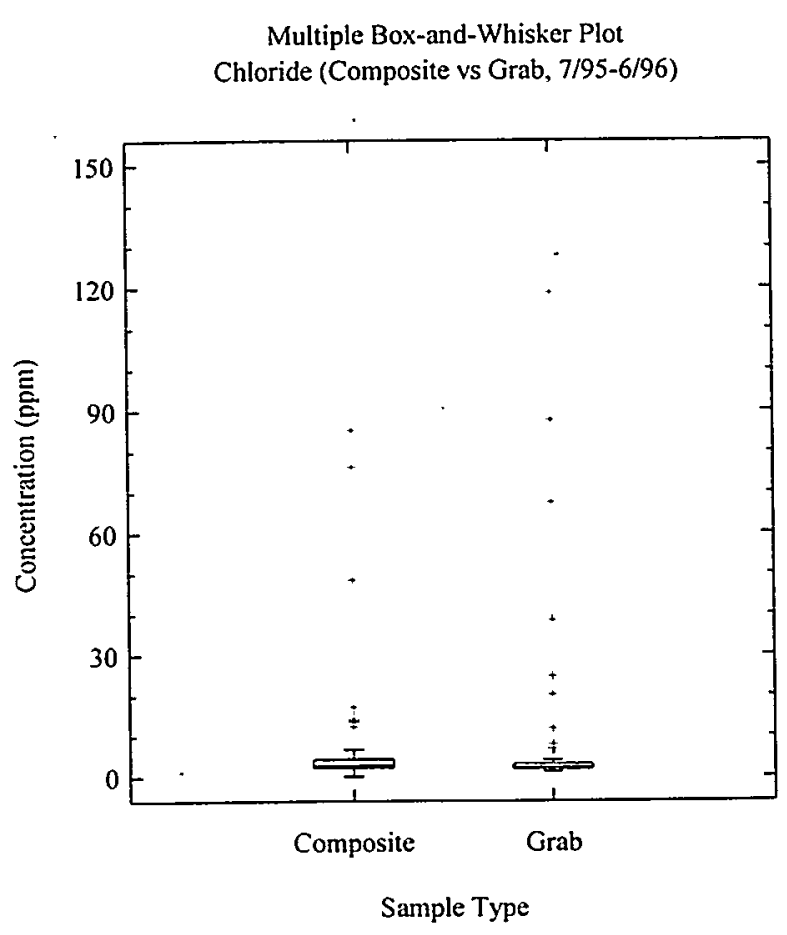

Figure B-33. Multiple Box and Whisker Plots - Chloride (Composite versus Grab Sample Results)

Multiple Box-and-Whisker Plot

Nitrate (Composite vs Grab, 7/95 - 6/96)

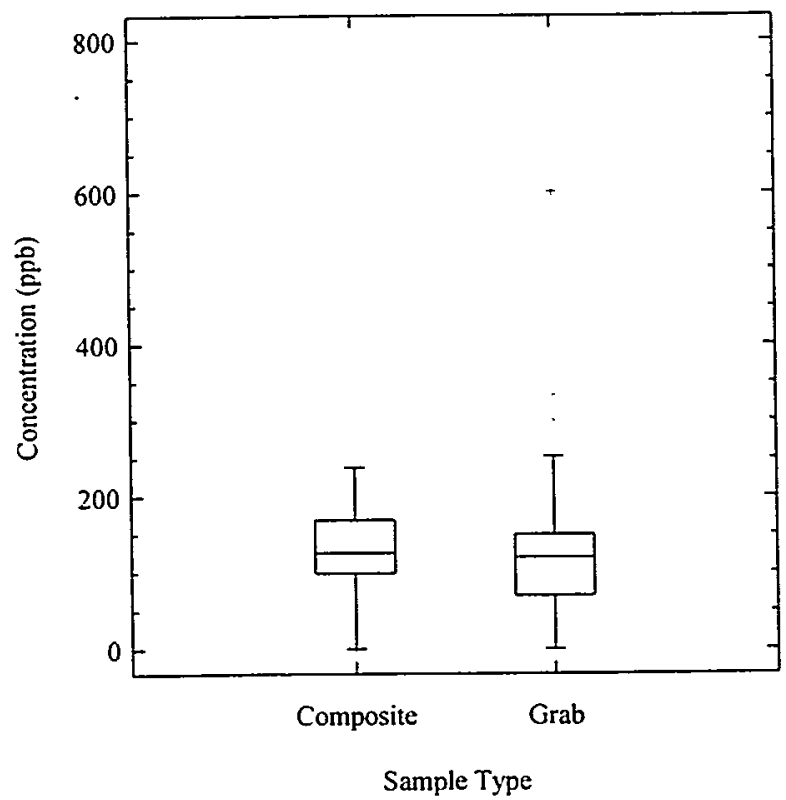

Figure B-34. Multiple Box and Whisker Plots - Nitrate (Composite versus Grab Sample Results) 


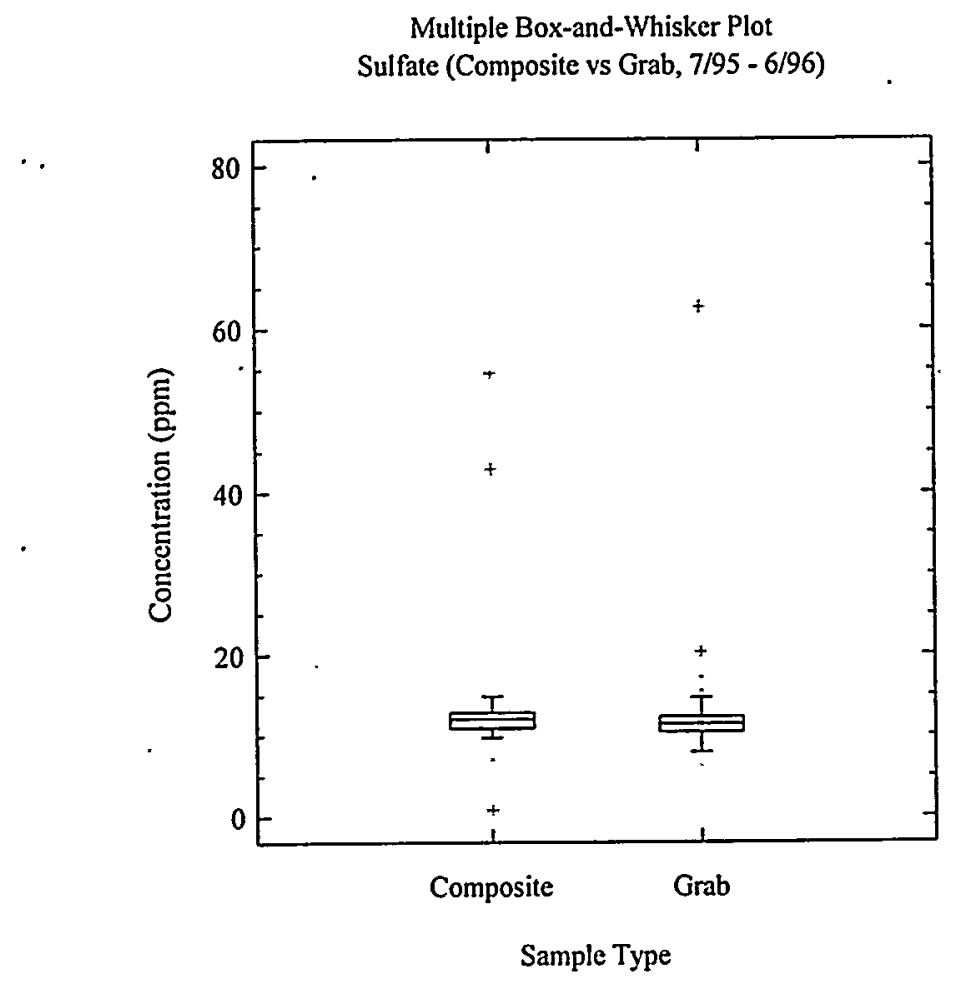

Figure B-35. Multiple Box and Whisker Plots - Sulfate (Composite versus Grab Sample Results)

Multiple Box-and-Whisker Plot

TDS (Composite vs Grab, 7/95 - 6/96)

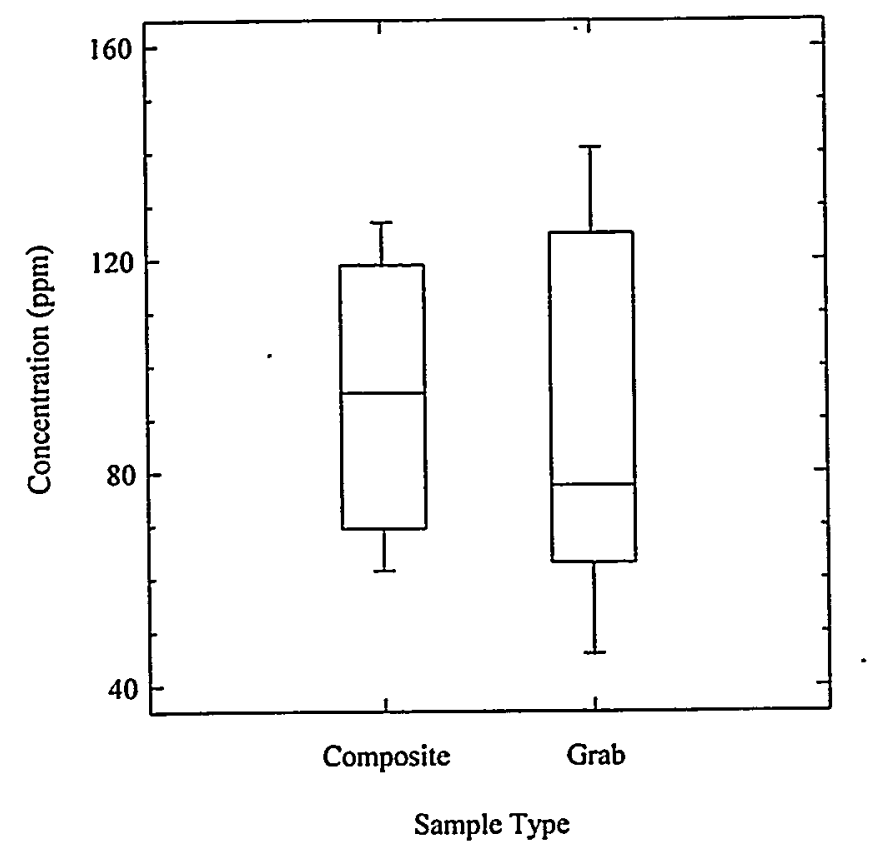

Figure B-36. Multiple Box and Whisker Plots - Total Dissolved Solids (Composite versus Grab Samples) 
Multiple Box-and-Whisker Plot

Gross Alpha(Composite vs Grab,7/95-6/96)

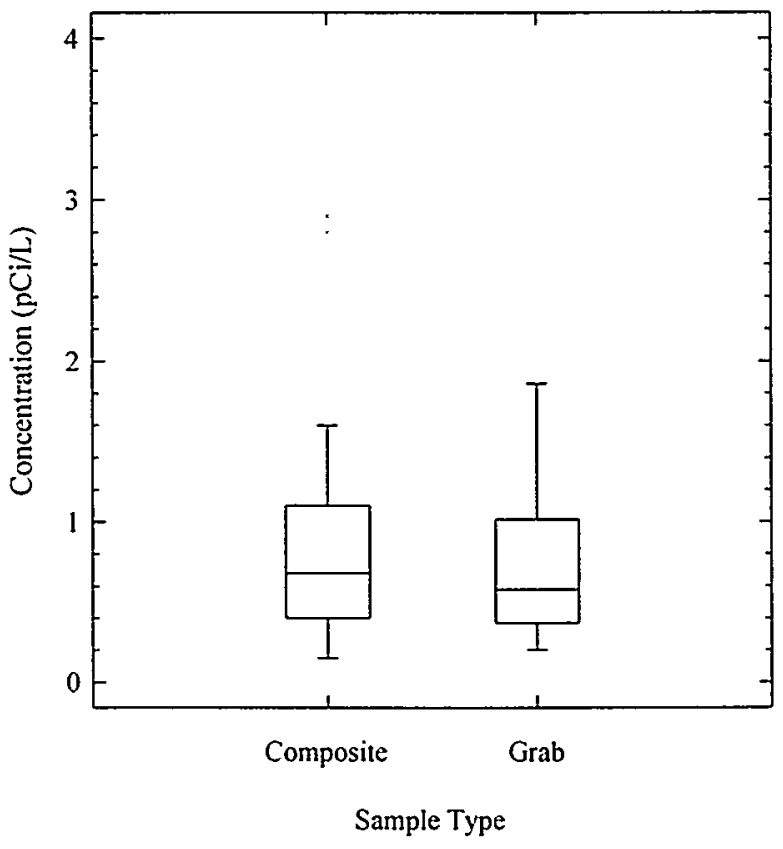

Figure B-37. Multiple Box and Whisker Plots - Gross Alpha (Composite versus Grab Sample Results)

Multiple Box-and-Whisker Plot

Gross Beta (Composite vs Grab.7/95-6/96)

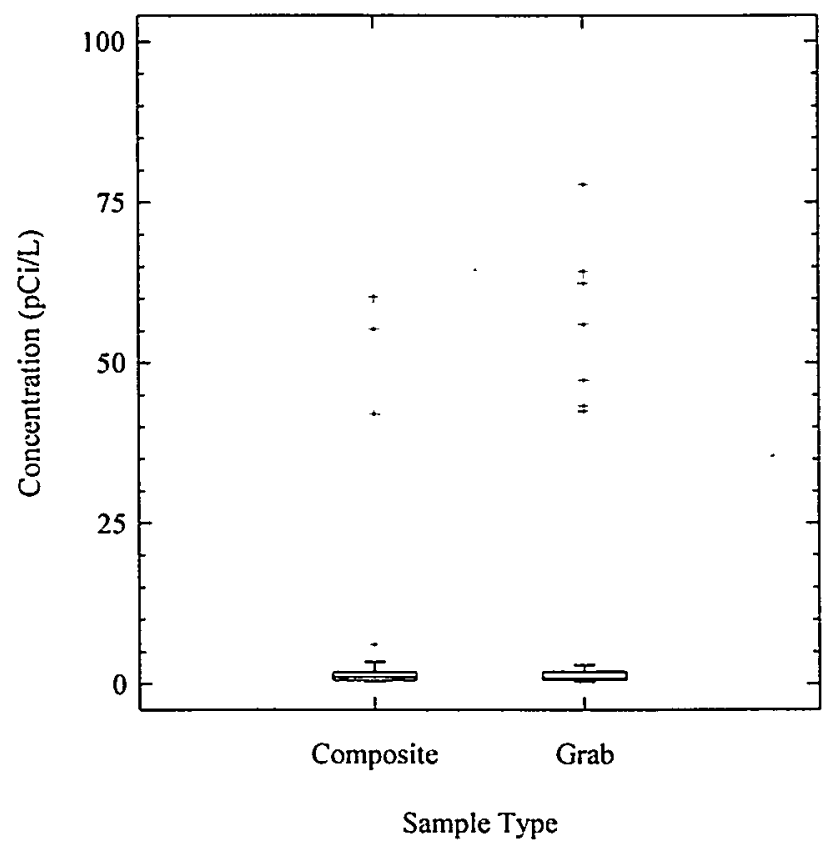

Figure B-38. Multiple Box and Whisker Plots - Gross Beta (Composite versus Grab Sample Results) 


\section{Distribution}

No. of

Copies

ONSITE

6 DOE Richland Operations Office
M. J. Furman
G. L. Sinton (5)

10 Fluor Hanford

M. J. Brown

K. L. Lueck

P. M. Olson (5)
No. of

Copies

D. K. Smith

S6-71

R: W. Szelmeczka

S6-72

LWPF Reg File

S6-72
A5- 13

$\mathrm{H} 0-12$

S6-72

S6-72

S6-72
20 Pacific Northwest National Laboratory

D. B. Barnett (3)

$\mathrm{K} 6-81$

J. G. Bush

$\mathrm{K} 6-96$

C. J. Chou (5)

K6-81

V. G. Johnson (3)

K6-96

W. J. Martin

K6-81

Information Release Office (7)

K1-06

Distr.1 